MÔNICA PEREIRA COELHO DE VASCONCELLOS

\title{
ICMS: DISTORÇÕES E MEDIDAS DE REFORMA
}

Mestrado em Direito

Orientador: Paulo Celso Bergstrom Bonilha.

Faculdade de Direito da Universidade de São Paulo São Paulo, 2013 


\title{
ICMS: DISTORÇÕES E MEDIDAS DE REFORMA
}

\author{
Mestrado em Direito
}

Dissertação apresentada à Banca Examinadora da Universidade de São Paulo, como exigência parcial para obtenção de título de MESTRE em Direito Econômico e Financeiro sob a orientação do Professor Paulo Celso Bergstrom Bonilha.

Faculdade de Direito da Universidade de São Paulo

São Paulo, 2013 
FolHa de Aprovação 


\section{AGRADECIMENTOS}

Aos meus pais, Mario e Ivonete, e irmãos, Mario Junior e Daniel, que, com muito carinho e apoio, não mediram esforços para que eu chegasse até esta etapa de minha vida.

Ao meu marido, Roberto, pela compreensão e apoio, principalmente quando nem eu acreditava que seria possível, e pelo exemplo de dedicação aos estudos e ao Direito Tributário.

Aos amigos Fernando e Ana Marta Zilveti, que, no começo de minha vida profissional, me incentivaram a iniciar o mestrado.

À Camilla Guimarães Junqueira Franco, pela amizade e incentivo.

Meus agradecimentos ao professor Paulo Bergstrom Bonilha, pelo incentivo, paciência e disposição para me orientar, tornando possível a conclusão desta monografia.

Aos professores e colegas do mestrado, que, de forma direta ou indireta, colaboraram para a conclusão deste trabalho.

À minha filha, Gabriela, que chegou nos últimos meses de minha dedicação a essa dissertação, mas, apesar de tão pequena, me proporcionou os momentos necessários de silêncio e tranquilidade para meus estudos. 


\section{RESUMO}

A dissertação tem por objetivo empreender uma análise, sob o ângulo jurídico, da tributação do consumo por meio do ICMS, que representa atualmente o tributo de maior arrecadação dentre tantos outros existentes em nosso país.

O estudo demonstra que, rompendo com a prática comum a outros países, de atribuir a tributação sobre o consumo ao poder central, no Brasil, a competência para instituição e a capacidade para cobrança do ICMS foram alocadas às diversas unidades subnacionais integrantes da Federação, que acabou provocando graves assimetrias e distorções em nosso sistema tributário.

Ademais, a estrutura consagrada constitucionalmente, chancelando a competência dos Estados da Federação relativamente ao ICMS, acirrou a guerra fiscal, praticada por meio da concessão de incentivos à margem da legislação vigente, de um lado, e, em contrapartida, a reação de alguns Estados, tão questionável quanto a própria concessão irregular de benefícios fiscais, no sentido de negar o reconhecimento do crédito de ICMS já pago em outras unidades da Federação.

O estudo concentra-se, portanto, em analisar o perfil do ICMS, as limitações ao aproveitamento de crédito e a consequente guerra fiscal, para tratar da possibilidade de reforma tributária que pretende alterar significativamente a estrutura do referido imposto, a fim de permitir uma convivência equilibrada entre os Entes da Federação, a fim de garantir uma política econômica voltada para aceleração do crescimento do país.

Palavras-chave: ICMS. Guerra Fiscal. Reforma Tributária. 


\begin{abstract}
The purpose of the dissertation is the analysis, from a legal viewpoint, of tax on consumption, through Sales Tax (ICMS), which currently represents the tax which is most paid among so many others existing in our country.

The study shows that, breaking with the common practice of other countries, namely, of attributing taxation on consumption to the central government, in Brazil, competence for the institution and capacity of imposing ICMs has been allocated to several sub-national units comprised in the government, which finally triggered severe asymmetries and distortions in our tax system.

Moreover, the structure constitutionally acknowledged, which approves the competence of the Federal States referent to the ICMS, intensified the fiscal war, practiced by concession of incentives beyond, on the one hand, the legislation in force, and, on the other, the reaction of some States, as questionable as the irregular concession of tax benefits, in the sense of refusing to acknowledge ICMS credit already paid in other Federal States.

The study is therefore focused on analyzing the ICMS features, the limitations for the offset of ICMS credits and the consequent fiscal war, in order to address the possibility of a tax reform which seeks to significantly alter the structure of aforesaid tax, in order to allow for a balanced relationship between the Federal States, so as to ensure an economic policy directed towards an upturn in the growth of the country.
\end{abstract}

Key words: ICMS. Fiscal War. Tax Reform. 


\section{SUMÁRIO}

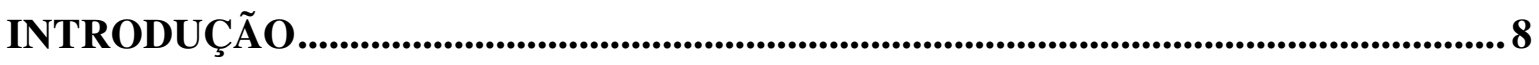

(i) Relação das características Essenciais da tributação sobre o consumo....................... 8

(ii) Apresentação do ICMS como imposto sobre o consumo........................................... 9

1 FORMAS DE TRIBUTAÇÃO DO CONSUMO ...................................................... 12

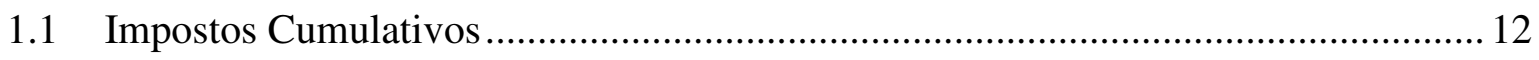

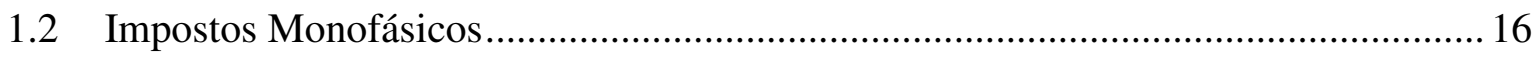

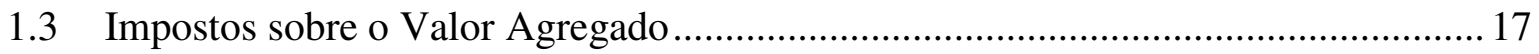

1.4 A Classificação "Impostos Diretos e Impostos Indiretos" .......................................23

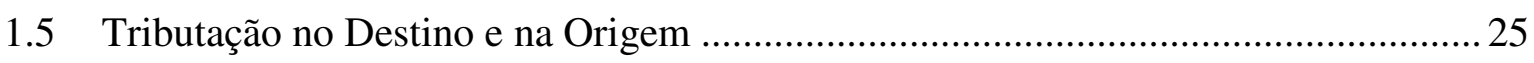

\section{PRINCÍPIOS INFORMADORES DA TRIBUTAÇÃO SOBRE O}

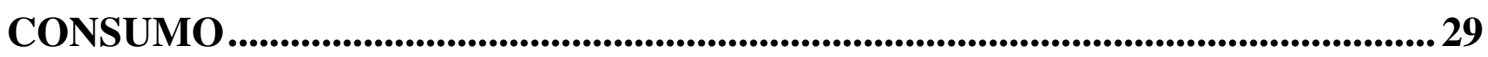

2.1 Princípio da Igualdade e Justiça Fiscal na Tributação ............................................ 29

2.1.1 Princípio da Capacidade Contributiva e a Tributação sobre o Consumo .............. 31

2.1.2 Seletividade como Mecanismo para Implementar o Princípio da Capacidade Contributiva na Tributação sobre o Consumo ..................................................... 41

2.2 Princípios da Uniformidade e da Unidade Econômico-Política............................ 4848

2.3 Princípio da Neutralidade Fiscal ............................................................. 5050

\section{IMPOSTO SOBRE A CIRCULAÇÃO DE MERCADORIAS E SERVIÇOS -}

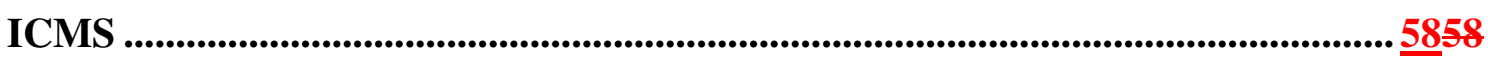

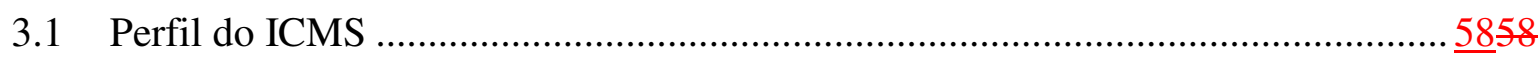

3.2 Aplicação do Princípio da Não Cumulatividade ao ICMS ................................... $\underline{6262}$

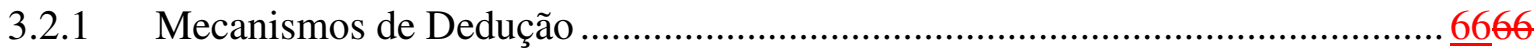

3.2.2 Créditos Físicos e Créditos Financeiros .............................................................. 6868

3.2.2.1 O Direito de Crédito e a Efetiva Cobrança nas Operações Anteriores .......... 7171

3.2.3 Regime de Substituição Tributária ............................................................... 7373

3.3 Restrições Constitucionais ao Princípio da Não Cumulatividade .......................... $\underline{8585}$ 
3.4 Alcance da Lei Complementar no que Concerne ao Princípio da Não Cumulatividade

4 O ICMS NO CONTEXTO DA GUERRA FISCAL $\underline{9090}$

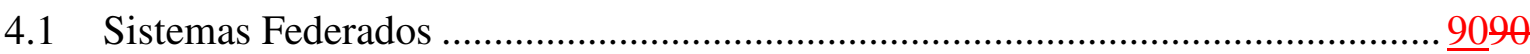

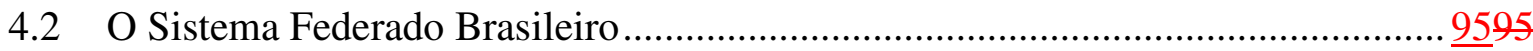

4.3 Guerra Fiscal entre os Estados da Federação Relativamente ao ICMS............... 107107

4.3.1 O Ajuizamento de ações declaratórias de inconstitucionalidade e seus efeitos

4.3.2 As formas de concessão de benefícios fiscais: créditos presumidos e benefícios financeiros

4.3.3 A Aplicação cumulativa da anulação do crédito e a exigibilidade do ICMS $\underline{119} 119$

5 ANÁLISE DE RECENTE PROPOSTA DE REFORMA TRIBUTÁRIA .......131131

5.1 O artigo 60, parágrafo 4 da Constituição Federal e a possibilidade de ampliação e modificação de competências tributárias e de reforma tributária

5.2 Análise da Proposta de Emenda Constitucional 233/2008 no Tocante à Reforma Tributária do ICMS

5.3 A Resolução $n^{\circ} 13$ de 2012 144

CONCLUSÃO $\underline{145145}$

REFERÊNCIAS 


\section{INTRODUÇÃO}

\section{(I) RELAÇÃo dAS CARACTERÍSTICAS ESSENCIAIS DA TRIBUTAÇÃo SOBRE O CONSUMO}

A tributação sobre o consumo baseia-se nos gastos e despesas incorridas pelos consumidores, enquadrando-se como forma indireta de tributação, pelo fato de o valor do tributo ser repassado ao consumidor.

Pode ser aplicada no momento do consumo final (monofásico), arrecadada em uma única etapa, ou durante o ciclo econômico, quando, ao incidir sobre todas as etapas (plurifásico), acaba também por onerar diretamente o consumo.

A tributação sobre o consumo poderá ser ainda cumulativa ou não cumulativa, o que irá impactar na intensidade da tributação final a ser suportada pelo consumidor.

A aplicação da tributação sobre o consumo, de forma predominante em um sistema tributário, foi severamente criticada por implicar em indesejável efeito regressivo, ao contrário do que sucederia com a tributação da renda auferida. ${ }^{1}$

No entanto, em virtude de estudos buscando demonstrar que a tributação da renda, a longo prazo, reduz as expectativas de crescimento da economia, recentemente, passou-se a admitir, ainda que em âmbito restrito, que a tributação sobre o consumo, a despeito do seu caráter regressivo, viabilizaria a expansão da poupança nacional. ${ }^{2}$

De fato, embora o ônus fiscal seja menor para as pessoas com maior poder aquisitivo, uma vez que incide somente sobre a parte consumida da renda, não afetando a poupada, estudos recentes constataram que a adoção apropriada da tributação sobre o consumo tem a capacidade de aumentar os níveis de bem-estar, mediante $(i)$ a aplicação de

1 SAMPAIO, Maria de Conceição. Tributação do consumo no Brasil: aspectos teóricos e aplicados. BIDERMAN, Ciro; ARVATE, Paulo (Orgs.). Economia do setor público no Brasil. Rio de Janeiro: Elsevier, 2004, p. 188.

2 Ibid., loc. cit. 
alíquotas progressivas, (ii) a concessão de benefícios fiscais e (iii) o respeito à capacidade contributiva, reduzindo as desigualdades. ${ }^{3}$

Ademais, apesar de a tributação indireta ser considerada uma das formas mais complexas de tributação existentes, são necessários baixos custos de administração para a arrecadação e a fiscalização dos tributos, reduzindo a possibilidade de evasão e elisão fiscal, bem como contribuindo para a correção de externalidades.

Dessa forma, considerando a importância e o crescimento da tributação sobre o consumo, representativa de uma parcela considerável da arrecadação total na maioria dos sistemas tributários nacionais, e seu impacto sobre as decisões de mercado, bem como a constante busca por uma tributação neutra, justa e eficiente do mercado de consumo, é imprescindível o estudo dessa forma de tributação.

\section{(II) APRESENTAÇÃO DO ICMS COMO IMPOSTO SOBRE O CONSUMO}

No Brasil, os impostos sobre o consumo representam grande parte da arrecadação. Enquanto a maior parte dos países dispõe de até dois tributos indiretos, o sistema brasileiro possui nove destes tributos (IPI, PIS, COFINS, II, IOF, ISS, ICMS, IE e CIDE), cada um deles com legislação diversa, complexa e em permanente alteração.

Entre os tributos indiretos no Brasil, o ICMS constitui o caso mais relevante, por ser o imposto de maior arrecadação em âmbito nacional e a mais significativa fonte de recursos dos Estados da Federação, participando de forma expressiva na composição da carga tributária nacional e na pressão fiscal exercida sobre os contribuintes.

Embora o ICMS seja invariavelmente enquadrado na categoria dos chamados tributos não cumulativos sobre o consumo (incidentes economicamente sobre o valor agregado às mercadorias e serviços em cada etapa da cadeia econômica), representando,

SAMPAIO, Maria de Conceição. Tributação do consumo no Brasil: aspectos teóricos e aplicados. BIDERMAN, Ciro; ARVATE, Paulo (Orgs.). Economia do setor público no Brasil. Rio de Janeiro: Elsevier, 2004, p. 189. 
destarte, um grande avanço em termos de política fiscal por promover a neutralidade tributária no ciclo econômico das mercadorias e serviços, o que afastaria o indesejável "efeito cascata", a ausência de uma política nacional uniforme possibilitou que se instalasse em nosso sistema uma série de restrições ao aproveitamento do crédito do ICMS, alterando profundamente o seu perfil "não cumulativo".

Rompendo com a prática comum a outros países de atribuir a tributação pelo consumo ao poder central, no Brasil, a competência para a instituição e a capacidade para a cobrança do ICMS foram alocadas às diversas unidades subnacionais integrantes da Federação. Consequentemente, além de se distanciar do modelo ideal em termos de eficiência alocativa, provocou profundas assimetrias e distorções em nosso sistema tributário, bem como a ruptura com diversos princípios gerais e outros especificamente tributários consagrados em nossa Constituição, como os da livre concorrência, capacidade contributiva e não cumulatividade, por exemplo, distorções que serão objeto do presente estudo.

Ademais, a estrutura consagrada constitucionalmente, chancelando a competência dos Estados da Federação relativamente ao ICMS, acirrou a guerra fiscal, praticada principalmente por meio da concessão de incentivos à margem da legislação vigente de um lado e, em contrapartida, a reação de alguns Estados, tão questionável quanto a própria concessão irregular de benefícios físcais, no sentido de negar o reconhecimento do crédito de ICMS já pago em outras unidades da Federação.

Tais movimentos provocam uma verdadeira anarquia tributária, acirrando cada vez mais a denominada guerra fiscal entre os Estados e comprometendo a principal característica do tributo - a neutralidade. Assim, não apenas comprometem a estrutura tributária do país, como abalam o já combalido pacto federativo delineado em nossa Constituição Federal.

Ainda no que toca ao tema proposto, será abordada a relação entre a tributação do consumo e o princípio da capacidade contributiva, admitindo-se este como corolário do conceito de Justiça Fiscal. Tal abordagem se faz necessária na medida em que tanto a doutrina jurídica como diversos estudos econômicos indicam ser a tributação da renda 
auferida a forma mais eficiente de atender ao primado da capacidade contributiva e, consequentemente, da Justiça Fiscal. Sobram, neste diapasão, críticas à ênfase da tributação sobre a chamada renda consumida, tal como sucede no caso do ICMS, que se desviaria do princípio da capacidade contributiva, não obstante a aplicação de alíquotas seletivas, gerando, assim, um indesejado efeito regressivo da tributação.

Outro aspecto que será abordado no trabalho diz respeito às diferentes técnicas para mitigação da cumulatividade dos tributos e, em especial, a adotada para o ICMS, considerada a sua incidência ao longo da cadeia produtiva.

A despeito de ser o ICMS um tributo incidente sobre o valor agregado, dificilmente podemos considerá-lo, de fato, neutro, consoante a legislação vigente, tanto no âmbito nacional como estadual, por conta de incontornáveis restrições ao aproveitamento do crédito de ICMS, cujos perniciosos efeitos se manifestam sob diversas formas, como se dá no caso da chamada verticalização da produção.

Desta forma, às limitações ao aproveitamento do crédito do tributo em questão será dedicada parte do presente trabalho, com enfoque no conjunto de prescrições legais relativas à não cumulatividade do ICMS em nível infraconstitucional, sobejamente nas leis complementares de caráter nacional como na legislação ordinária dos Estados.

Todas essas distorções fazem com que o ICMS seja o foco principal da discussão sobre a reforma tributária.

Assim, é fundamental o desenvolvimento de estudo que analise o atual cenário de tributação sobre o consumo no Brasil, identificando suas principais características e problemas, comentando as propostas de reforma tributária, especialmente a do Governo, que pretende unificar os impostos sobre a produção e o consumo em um único tributo incidente sobre o valor agregado devido no destino, bem como outras propostas que incentivam a criação de um IVA-Federal, de forma a indicar caminhos e tendências atuais, combatendo a guerra fiscal, o que permitirá a convivência equilibrada dos entes da Federação, a fim de garantir uma política econômica voltada para a aceleração do crescimento do país. 


\section{FORMAS DE TRIBUTAÇÃO DO CONSUMO}

Alguns esclarecimentos preliminares devem ser feitos quanto à tributação do consumo, antes de tratar de suas formas de aplicação.

Para a OCDE, impostos sobre o consumo são "aqueles que se pagam no contexto da utilização de bens e serviços finais no país onde são consumidos”4.

A tributação sobre o consumo atinge diretamente as despesas efetuadas pelos consumidores. Significa dizer que não incide sobre o custo do produtor ou do vendedor na produção e comercialização do bem, mas sobre a "quantia que representa o valor que o consumidor terá de assumir para usufruir de determinado bem ou serviço produzido por outrem",

Nem todas as despesas dos consumidores podem ser integralmente incluídas na base de cálculo dos tributos sobre o consumo, em virtude de questões sociais, política fiscal ou até mesmo pela impossibilidade prática da incidência.

Definido o que se entende por tributação sobre o consumo, passaremos a tratar das formas como se pode impor a sua incidência.

\subsection{Impostos Cumulativos}

O vocábulo cumulativo denota o sentido de acréscimo, aumento.

Nessa linha, tem-se que a noção de tributo cumulativo está relacionada com a sobreposição do valor que incide sucessivamente em cada uma das fases do ciclo econômico, desde a produção até a comercialização do produto, englobando o valor total de cada operação, inclusive o valor do tributo anteriormente pago.

4 BASTO, José Guilherme Xavier de. A tributação do consumo e a sua coordenação internacional. Lisboa: Centro de Estudos Fiscais, 1991, p. 14.

5 TEIXEIRA, Alessandra Machado Brandão. A Tributação sobre o Consumo de Bens e Serviços. Belo Horizonte: Mandamentos, 2002, p. 64. 
Ou seja, a incidência cumulativa se dá quando houver a incidência de um tributo em cada etapa da cadeia de operações tributáveis, englobando o valor total das operações e do próprio tributo pago.

As vantagens da adoção deste método de tributação estão relacionadas com a facilidade de aplicação e compreensão do cálculo e, consequentemente, facilidade de arrecadação e fiscalização, na possibilidade de garantir um volume considerável de arrecadação, mesmo com a aplicação de alíquotas moderadas, em virtude da ampla base de cálculo, e de diluir o impacto tributário entre um número maior de contribuintes.

No entanto, tendo em vista que o valor do tributo se incorpora ao valor e preço da operação, provocando a ampliação da base de cálculo da incidência posterior, esse método resulta no que se denomina de incidência de imposto em cascata.

Isso porque a tributação pelo regime da cumulatividade em todas as fases de venda, do ciclo econômico, sem o aproveitamento de créditos, gera uma elevada carga tributária a ser paga.

Nesse sentido, Caliendo ${ }^{6}$ conclui: "diferentemente do que ocorre no regime da nãocumulatividade, não há a manutenção de créditos pagos nas operações anteriores, fazendo com que o imposto incida em cascata, aumentando significativamente o montante do imposto pago no ciclo econômico [...]."

Ou seja, sendo o tributo exigido em todas as etapas, há uma superposição de cada fração originada da incidência anterior, que também passa a integrar a base sobre a qual será calculado o tributo na operação seguinte ${ }^{7}$.

Dessa forma, a tributação cumulativa implica uma tributação múltipla, que conduz a uma excessiva verticalização da produção.

6 SILVEIRA, Paulo Antônio Caliendo Velloso da. Direito tributário e análise econômica do Direito: uma visão crítica. Rio de Janeiro: Elsevier, 2009, p. 326.

7 CINTRA, Carlos César Sousa. A Não-Cumulatividade no Direito Tributário Brasileiro: Teoria e Prática. In: MACHADO, Hugo de Brito. Não-Cumulatividade Tributária. São Paulo: Dialética, 2009, p. 110. 
Isso porque quanto maior a cadeia de produção e comercialização - cadeias com mais etapas -, maior será a tributação. Significa dizer que produtos sujeitos a uma cadeia mais longa estarão sujeitos a uma carga tributária mais elevada, podendo-se concluir que a cumulatividade dispensa tratamento desigual aos produtos, em função de seus circuitos de produção e comercialização, desviando-se da neutralidade fiscal.

Para evitar essa distorção, busca-se a maior integração vertical possível das empresas, com o objetivo de reduzir o número de operações da cadeia até o consumidor final, diminuindo, consequentemente, o ônus tributário das mercadorias comercializadas.

Exemplificando a tributação diferenciada em virtude do número de etapas na cadeia de produção, Alcides Jorge Costa cita o comércio de algodão. De acordo com o autor, em 1960, o Estado de São Paulo foi forçado a instituir a Lei $n^{\circ}$ 6.026, concedendo isenção do tributo para vendas e consignações de algodão em pluma ${ }^{8}$, uma vez que, para diminuir a tributação que sofriam, as empresas de grande porte econômico começaram a manter suas próprias máquinas de beneficiamento do produto, buscando verticalizar a produção. Assim, referidas empresas passaram a pagar o tributo apenas na compra do algodão do produtor e na revenda à indústria ou na exportação, enquanto as pequenas empresas ficavam sujeitas a mais uma incidência, no mínimo, a venda do beneficiador à indústria ou ao exportador, ameaçando a atuação destes no mercado em razão da desvantagem que a maior tributação trazia. $^{9}$

Outra desvantagem da tributação cumulativa é a impossibilidade de desoneração total de produtos destinados à exportação, prejudicando a adoção de política de incentivo a essas operações. Além disso, o produto proveniente do exterior, por operação de importação e destinado à venda direta ao consumidor final, fica em posição favorecida em comparação com os produtos nacionais.

8 Exceto quando realizadas para fora do país ou quando feitas a indústrias que adquiriam o produto para utilizá-lo em suas indústrias.

9 COSTA, Alcides Jorge. ICM na Constituição e na Lei Complementar. São Paulo: Resenha Tributária, 1979, p. 8. 
Como se não bastasse, a tributação cumulativa não distribui uma carga uniforme para todos os consumidores, que, efetivamente, são os que suportam o encargo/ônus econômico da tributação sobre o consumo. Isso porque a essencialidade do tributo não tem nenhuma relação e influência sobre a extensão dos ciclos de produção e comercialização.

Em decorrência, há situações em que os produtos essenciais são mais onerados do que produtos considerados supérfluos, por resultarem de cadeias de produção e comercialização mais longas, sujeitas a um ônus econômico maior.

Misabel Abreu Machado Derzi ${ }^{10}$, ao tratar dos efeitos negativos da tributação cumulativa, resume estudo de Gómez Sabaini, baseado na obra de John Due, apontando os seguintes efeitos:

a) distorção da alocação dos recursos econômicos, em razão da ausência de neutralidade que resulta na alteração de preços, desde o produtor até o consumidor final, ou seja, não há neutralidade na competitividade;

b) distorção no preço dos bens, maior ou menor proporcionalmente à possibilidade de integração vertical de cada setor;

c) desestímulo à exportação, com a oneração da produção e não do consumo, uma vez que não se pode devolver o imposto contido nos insumos e bens de capital, incorporados ao valor do bem exportado;

d) estímulo à importação de bens (especialmente acabados), isso porque o tributo incidente sobre a importação atinge apenas a etapa final deles, enquanto os produtos domésticos estão sujeitos à incidência, cumulativa, em todas as suas etapas;

10 DERZI, Misabel Abreu Machado. Distorções do Princípio da não-cumulatividade no ICMS Comparação com o IVA Europeu. In: COELHO, Sacha Calmon Navarro et al. Temas de Direito Tributário: I Congresso Nacional da Associação Brasileira de Direito Tributário. Belo Horizonte: Livraria Del Rey, 1998, p. 112. 
e) efeitos nos preços finais de aumento progressivo;

f) gastos excessivos com a administração e fiscalização, já que é necessária uma fiscalização ampla, plurifásica e sem nenhum tipo de vinculação entre contribuintes, como ocorre no sistema de compensação em que o débito de um contribuinte é o crédito de outro.

Caliendo ${ }^{11}$ adiciona aos referidos problemas $(i)$ inibição do crescimento econômico, pela excessiva tributação dos bens de capital, uma vez que impõe excessiva incidência direta ou indireta sobre os insumos necessários à produção de bens complexos e sofisticados, (ii) ausência de justiça fiscal, uma vez que a cumulatividade tende a afetar de forma desigual os setores econômicos, o que pode gerar uma tributação regressiva ou mais gravosa para produtos necessários à população de baixa renda (remédios, eletrodomésticos etc.) e (iii) ofensa à capacidade contributiva, pelo fato de que a cumulatividade tende a afetar aqueles que têm menor poder aquisitivo, tributando mais, proporcionalmente, do que aqueles que recebem menos.

\subsection{IMPOSTOS MONOFÁSICOS}

Os impostos monofásicos incidem em apenas uma fase do processo produtivo.

Podem ser aplicados no início ou no final da cadeia produtiva.

Na primeira situação, há o risco de haver uma tributação com efeito em cascata (cumulativa). Assim, a incidência nas etapas finais do ciclo produtivo, especialmente na venda direta ao consumidor final, é a mais adequada para se evitar tal efeito.

Essa forma de tributação, entretanto, não observa que os produtores também adquirem bens e serviços na condição de consumidores finais. E nessa sistemática de tributação, o valor do imposto passa a integrar o custo de produção, uma vez que seu valor

11 SILVEIRA, Paulo Antônio Caliendo Velloso da. Direito tributário e análise econômica do Direito: uma visão crítica. Rio de Janeiro: Elsevier, 2009, p. 323. 
não pode ser deduzido dos valores a serem pagos, nas operações subsequentes de circulação de bens e serviços. ${ }^{12}$

Para evitar tal efeito, é necessário que se excluam da tributação as operações de aquisição de bens necessários à produção. Ou seja, deve-se autorizar que os sujeitos passivos efetuem vendas, sem a incidência do imposto, quando os adquirentes também se enquadrarem como outros sujeitos passivos. ${ }^{13}$

Para que se tenha uma tributação monofásica, com efeitos positivos equiparados aos do imposto sobre o valor acrescentado, a incidência deve recair sobre o varejo, ou seja, na venda direta ao consumidor. $\mathrm{O}$ aspecto negativo dessa sistemática é a vulnerabilidade à fraude, pois, no curso da cadeia de circulação, não há o controle efetuado pelos sujeitos envolvidos nas operações, como ocorre nos impostos plurifásicos, nos quais o direito de crédito está atrelado ao débito da operação anterior. ${ }^{14}$

\subsection{IMPOSTOS SOBRE O VALOR AGREGADO}

Em linhas gerais, Rolim ${ }^{15}$ afirma que o valor agregado é o valor que o agente econômico acrescenta aos seus insumos e compras (com exceção dos salários) anteriormente à operação de venda ou revenda de seu produto no mercado.

Dessa forma, tributar o valor agregado significa tributar a operação que agrega valor a bens ou serviços. Nesse contexto, considerando que o fato gerador da obrigação tributária é o valor que o agente econômico agrega/acrescenta, a base de cálculo do tributo deverá ser este valor agregado que o produto adquire em relação à etapa anterior.

O valor total do produto na sua última fase do ciclo de produção e comercialização corresponde à soma do valor inicial da mercadoria na primeira etapa, com os valores

12 TEIXEIRA, Alessandra Machado Brandão. A Tributação sobre o Consumo de Bens e Serviços. Belo Horizonte: Mandamentos, 2002, p. 72.

13 Ibid., p. 72.

14 Ibid., p. 73.

15 ROLIM, João Dácio. Não-Cumulatividade (Valor Agregado?). In: MACHADO, Hugo de Brito (Coord.). Não-Cumulatividade Tributária. São Paulo: Dialética, 2009, p. 253. 
acrescidos em todas as demais etapas, sendo que a soma das incidências do imposto sobre os valores acrescidos em todas as etapas equivale a uma incidência global da alíquota sobre o valor final do produto.

Assim, é o imposto do tipo plurifásico, incidente sobre o valor acrescido e não cumulativo.

Ylves José de Miranda Guimarães ${ }^{16}$, citando o estudo elaborado por Cesare Cosciani ${ }^{17}$, destaca que a adoção da tributação sobre o valor acrescido apresenta uma série de vantagens.

De início, tem-se o tratamento de igualdade dispensado aos produtos com menores ou maiores ciclos de produção e comercialização. Ou seja, por não se tratar de imposto cumulativo, mas de incidência apenas sobre o valor acrescido, o número de etapas no ciclo de produção e comercialização não influi na incidência, evitando-se a integração do ciclo pela verticalização das empresas.

De fato, há uniformidade de tratamento, mesmo nos casos em que persistem disparidades de setor a setor, de empresa a empresa, e no emprego de diferentes fatores de produção no ciclo de produção e de comercialização.

O método do valor acrescido permite ainda que a carga tributária seja repartida por todo o ciclo de produção e comercialização, diluindo o ônus econômico entre todos os integrantes do circuito e criando uma relação de interdependência e oposição de interesses entre os contribuintes. Isso coopera para que todos os contribuintes tenham interesse em escriturar adequadamente sua contabilidade, para aumentar o máximo possível as somas dedutíveis. Assim, diminui-se, inclusive, a evasão fiscal, pois se reduz o interesse nas compras sem a emissão de notas fiscais.

16 GUIMARÃES, Ylves José de Miranda Guimarães. ICM: Análise e Princípios Estruturais. São Paulo: Ltr, 1975, p. 165.

17 O autor cita a obra El impuesto al Valor Agregado. Buenos Aires: Depalma, 1969, de Cesare Cosciani. 
Ademais, a manutenção adequada da contabilidade, para os fins citados no parágrafo acima, auxiliam na fiscalização e arrecadação de impostos diretos, unificando uma série de procedimentos e obrigações.

Com relação às operações de exportação e de importação, há a facilitação do cômputo das compensações nas referidas operações. Favorece-se o controle adequado da desoneração nas exportações, uma vez que o método possibilita o cálculo exato da carga tributária em todas as etapas e, ainda, permite o cálculo equitativo da incidência sobre os bens importados. Dessa forma, é possível obter considerável neutralidade no comércio internacional.

Fernando Rezende ${ }^{18}$ resume as vantagens do imposto sobre o valor agregado, pontuando-as da seguinte forma:

a) permite uma tributação mais neutra ${ }^{19}$, respeitando as escolhas dos consumidores e produtores, o que permite a tributação dos consumidores e não dos insumos utilizados nas etapas da cadeia produtiva;

b) permite a ampla tributação dos serviços;

c) reduz as distorções fiscais no que se refere às operações de comércio exterior;

d) facilita o controle de evasão fiscal;

e) permite a ampliação da arrecadação, atingindo eficazmente as rendas de consumo.

18 REZENDE, Fernando. A Moderna Tributação do Consumo in Reforma Fiscal. In: MATTOS FILHO, Ary Oswaldo (Coord.). Reforma Fiscal. Coletânea de Estudos Técnicos - Relatório da Comissão Executiva de Reforma Fiscal, v. II. São Paulo: DBA Dórea Books, 1993.

19 Sobre a neutralidade, Caliendo destaca que o "princípio da não-cumulatividade é uma forma de alcançar os nos tributos sobre o consumo o respeito à neutralidade fiscal, permitindo que as decisões dos agentes econômicos não sejam distorcidas pelo peso da tributação e tampouco que os consumidores sejam afetados por uma tributação excessiva e regressiva." (SILVEIRA, Paulo Antônio Caliendo Velloso da. Direito tributário e análise econômica do Direito: uma visão crítica. Rio de Janeiro: Elsevier, 2009, p. $324)$. 
Há duas formas de cálculo do imposto sobre o valor acrescido.

A forma "pura" ou "base real" consiste na adoção de métodos estatísticos e de avaliação de estoques, que permitem a apuração do valor acrescido através da dedução do valor da produção de um determinado período (produtos vendidos e ainda em estoque) do montante correspondente aos gastos de aquisição das matérias-primas, materiais secundários e equipamentos utilizados na produção desses bens. Conclui-se, assim, que esta forma de cálculo se atém ao conceito estatístico e econômico de valor acrescido.

Na segunda forma, do cálculo sobre bases financeiras, obtém-se o valor acrescido mediante a dedução do total das vendas realizadas em um determinado período do valor das aquisições de matérias-primas e materiais secundários efetuadas no mesmo período, desconsiderando-se se os bens foram produzidos ou os insumos utilizados durante o período em referência.

Paulo Bergstrom Bonilha ${ }^{20}$ destaca que o primeiro método é de difícil aplicação e, por isso, pouco utilizado na prática. Isso porque, para sua adoção, seria necessário o emprego de métodos de avaliação semelhantes aos de avaliação dos estoques de fim de exercício (custo histórico, custo médio, custo standard, LIFO, FIFO). Dessa forma, o método sobre bases financeiras é o geralmente adotado, por razões de praticidade.

Há, ainda, a diferenciação da forma de cálculo em função do tratamento dispensado aos bens de produção. Têm-se as seguintes possibilidades:

IVA-Produto: não autoriza nenhuma dedução referente aos bens de produção, tributando todas as despesas. A base global do tributo equivale ao total das vendas de varejo acrescido das vendas dos bens instrumentais.

IVA-Renda: autoriza deduções parciais, possibilitando a exclusão da depreciação. Isso porque a depreciação não representa investimentos adicionais, destina-se

20 BONILHA, Paulo Celso Bergstrom. IPI e ICMS: Fundamentos da Técnica não cumulativa. São Paulo: Resenha Tributária; IBDT - Instituto Brasileiro de Direito Tributário, 1979, p. 33. 
somente à substituição do capital investido. ${ }^{21}$ Ou seja, as despesas com depreciação não dão origem a rendimentos líquidos, destinando-se apenas à garantia da manutenção dos níveis de renda.

Pode-se concluir, assim, que o IVA-Renda não tributa o investimento bruto, mas o investimento líquido.

IVA-Consumo: faculta a dedução total do valor dos bens de produção. Tal faculdade justifica-se no entendimento de que os bens de produção aumentam o estoque de capital e contribuem para a expansão da produção, não representando, assim, uma base adequada para um imposto sobre o consumo. Por esse motivo, além de excluir a depreciação, no IVA-Consumo também se eliminam os gastos com bem de capitais.

Comparando-se as três possibilidades, deve se observar que IVA-Produto, por não permitir nenhuma dedução, tem a base de cálculo mais ampla, o que desencoraja o investimento. Ademais, o IVA-Produto pode se tornar um imposto cumulativo, na medida em que é repassado para frente. Os mesmos comentários podem ser aplicados ao IVARenda, embora em proporções menos significativas, já que, neste caso, são permitidas deduções parciais. $^{22}$

Por sua vez, o IVA-Consumo, que tem a menor base, na medida em que permite a dedução total dos bens mencionados, é o mais neutro. Isso porque não gera distorções entre o capital e os outros insumos. No entanto, a menor base exige a aplicação de alíquotas mais elevadas, resultando numa carga tributária maior.

Quanto aos métodos de cálculo, é possível obter o valor acrescido através de dois métodos: o de adição e o de subtração.

21 SAMPAIO, Maria de Conceição. Tributação do consumo no Brasil: aspectos teóricos e aplicados. BIDERMAN, Ciro; ARVATE, Paulo (Orgs.). Economia do setor público no Brasil. Rio de Janeiro: Elsevier, 2004, p. 191.

22 Ibid., p. 192. 
No método de adição, somam-se todos os componentes de uma empresa (salários, lucros líquidos, juros, depreciações, etc.).

O método da subtração pode se calculado na forma "base sobre base" ou "imposto sobre imposto".

No cálculo da "base sobre base", o valor acrescido é obtido mediante a apuração da diferença entre o valor das vendas e o montante das aquisições, em um período determinado.

No cálculo "imposto sobre imposto", o valor acrescido é calculado através da dedução do imposto a pagar do montante do imposto que incidiu sobre os bens adquiridos, em um mesmo período determinado.

A tributação sobre o valor agregado também apresenta algumas desvantagens.

Primeiramente, porque esta forma de tributação é baseada no controle do imposto na contabilidade elaborada pelos contribuintes, o que possibilita a evasão, nos casos em que a contabilidade não é adequadamente escriturada. Assim, é imperioso que estes operadores econômicos possuam efetivamente a contabilidade regular.

Dessa forma, para que se tenha um imposto sobre o valor agregado eficaz, deve-se evitar ou diminuir as isenções e demais benefícios fiscais.

Ademais, a tributação sobre o valor acrescido não se compadece com a concessão de benefícios, o que dificulta a administração do tributo. Isso porque "é fundamental o encadeamento entre as incidências parciais e sucessivas durante o 'iter' perpassado pelo produto desde a fonte produtora até a etapa final da venda ao consumidor,"23.

Tem-se, ainda, a dificuldade em identificar quais valores podem ser deduzidos para o cálculo do imposto a ser pago, $(i)$ se todos ou apenas parte dos bens adquiridos (ii) como

23 BONILHA, Paulo Celso Bergstrom. IPI e ICMS: Fundamentos da Técnica não cumulativa. São Paulo: Resenha Tributária; IBDT - Instituto Brasileiro de Direito Tributário, 1979, p. 32. 
se procede a dedução dos bens que têm vida útil distribuída por mais de um determinado período (instituição ou não de cotas de amortização), (iii) cômputo ou não das variações de estoque.

Por último, são apontados também problemas de aplicações práticas do método, que podem produzir distorções no princípio geral, que complicam o próprio sistema.

Entre outras situações, Ylves José de Miranda Guimarães ${ }^{24}$ ressalta que as isenções, concedidas em regimes especiais, criam complicações na administração do tributo e sérias perturbações no funcionamento normal do sistema do tributo. Além disso, também cita a dificuldade na introdução de alíquotas diferenciadas por setores ou produtos.

De qualquer forma, mesmo diante da complexidade para a arrecadação, administração e fiscalização - que pode ser regulada mediante a aplicação de providências administrativas adequadas -, a tributação sobre o valor agregado é considerada a mais compatível com as exigências econômicas.

\subsection{A ClASSIFICAÇÃO "IMPOSTOS Diretos E IMPOSTOS INDIRETOS"}

Muito se discute sobre a classificação dos impostos em "diretos" e "indiretos".

Há doutrinadores que a consideram uma classificação não jurídica, por estar baseada em critério de diferenciação puramente econômico, não aplicável para fins jurídicos.

No entanto, embora se afirme que a classificação dos tributos deva levar em consideração exclusivamente critérios jurídicos, não há impedimentos para a adoção deste critério pelo Código Tributário Nacional, ainda mais tendo em conta tratar-se de norma jurídica que aborda justamente o efeito econômico dos tributos. Não há como negar que,

24 GUIMARÃES, Ylves José de Miranda Guimarães. ICM: Análise e Princípios Estruturais. São Paulo: Ltr, 1975, p. 168. 
apesar de esta classificação ser baseada em características econômicas, tem reflexos jurídicos.

Assim, apesar das críticas, Laptaza ${ }^{25}$ destaca que esta talvez seja a classificação mais difundida nos diferentes sistemas tributários. Nesse sentido, o autor esclarece que o critério de distinção reside no objeto da tributação, ou seja, na riqueza gravada por cada um deles: impostos diretos e impostos indiretos.

Dessa forma, a classificação será feita considerando-se as bases de incidência dos tributos, renda, patrimônio ou despesas ou utilização das rendas (consumo).

Sabe-se que, ao instituir tributos, o legislador, geralmente, observa situações de riqueza e a capacidade econômica dos contribuintes para suportá-los. Em regra, a capacidade contributiva e a riqueza dos contribuintes são evidenciadas, de forma direta e imediata, pelo seu patrimônio e pela sua apuração de renda. Assim, são classificados como "impostos diretos", tradicionalmente, os impostos sobre a renda e o patrimônio, uma vez que incidem sobre a riqueza em si mesma, direta e imediatamente considerada.

Por outro lado, a riqueza também pode ser evidenciada, de forma indireta, pela despesa e utilização de renda pelos contribuintes. Assim, são classificadas como "impostos indiretos" as manifestações indiretas de capacidade contributiva, que são a circulação ou o consumo da riqueza.

Caliendo $^{26}$ refere-se aos tributos indiretos como aqueles que não cobrados diretamente do contribuinte, mas de comerciantes ou industriais, mediante o acréscimo do valor do tributo no preço da mercadoria e seu respectivo recolhimento.

25 FERREIRO LAPTAZA, José Juan. Direito Tributário: teoria geral do tributo. Barueri, SP: Manole, 2007, p. 164-165

26 SILVEIRA, Paulo Antônio Caliendo Velloso da. Direito tributário e análise econômica do Direito: uma visão crítica. Rio de Janeiro: Elsevier, 2009, p. 319. 


\subsection{TributaÇÃo no DeStino E Na ORIGEM}

A tributação de acordo com o princípio do destino e da origem tem como critério a locação da produção e do consumo, e não considera o tipo de produto ou características pessoais das partes envolvidas.

No caso da tributação na origem, o imposto recai sobre todos os bens e serviços no território em que são produzidos, independentemente do território em que consumidos.

Assim, as mercadorias e serviços que circulam de um Estado para outro, independentemente de seu destino, incorporam, no preço, os imposto pagos no Estado de origem, de forma que inexiste interrupção na cadeia de operações do produtor ao consumidor final. $^{27}$

Os Estados de destino devem aceitar os créditos gerados no Estado de origem, para o abatimento do imposto devido a ele.

Dessa forma, as exportações são tributadas e as importações não, resultando em uma unidade de mercado, uma vez que não há a imposição de uma tributação que limite a circulação de bens e serviços.

Neste caso, as operações de importação não competem em situação de igualdade com as operações internas (produtos nacionais).

Assim, para que o princípio da tributação na origem tenha efetividade, é necessário, sob o aspecto econômico, que os Estados, na qualidade de centros de consumo e não de produção - ou seja, os Estados destinatários -, procurem soluções internas para resolver seus problemas fiscais, já que as operações das quais são destinatários não competem igualmente com as operações internas, conforme mencionado.

27 DERZI, Misabel Abreu Machado. Distorções do Princípio da não-cumulatividade no ICMS Comparação com o IVA Europeu. In: COELHO, Sacha Calmon Navarro et al. Temas de Direito Tributário: I Congresso Nacional da Associação Brasileira de Direito Tributário. Belo Horizonte: Livraria Del Rey, 1998, p. 122. 
Isso porque os Estados têm um controle e política própria sobre as operações internas, que não são aplicáveis às operações externas, uma vez que estas são oneradas pela tributação na origem, tributação que será diminuída do tributo incidente na operação subsequente no Estado destinatário. ${ }^{28}$

Tem-se, portanto, que a tributação na origem é a mais evoluída no que se refere à integração político-econômica; no entanto, é considerada forma complexa de tributação, uma vez que exige um rigoroso controle interno sobre os incentivos e demais benefícios. ${ }^{29}$

Quanto ao princípio do destino, Ricardo Lobo Torres $^{30}$ destaca que este está em íntima relação com o princípio da territorialidade, uma vez que ambos devem se harmonizar, com o objetivo de evitar a dupla tributação.

Na tributação no destino, o imposto incide sobre os bens e serviços consumidos no país. Neste caso, as exportações não são tributadas e as importações estão sujeitas à tributação, de acordo com as mesmas regras aplicáveis às operações internas (produtos nacionais).

Ou seja, os Estados que destinam seus produtos e serviços para outros Estados deixam de auferir receita tributária, em favor dos Estados destinatários.

Misabel Abreu Machado Derzi ${ }^{31}$ esclarece:

Para isso, o Estado de origem devolve o tributo pago nas operações anteriores (manutenção de créditos), quer nas etapas de comercialização, quer naquelas de industrialização, de tal forma que os bens se submetem

28 RONZANI, Guilherme Della Garza. Princípios da Tributação na Origem e da Tributação no Destino no Contexto da 'Guerra Fiscal'. In: SILVA, Paulo Roberto Coimbra; BERNARDES, Flavio Couto; FONSECA, Maria Juliana (Coords.). Tributação sobre o Consumo. São Paulo: Quartier Latin, 2008, p. 198.

29 DERZI, Misabel Abreu Machado. Distorções do Princípio da não-cumulatividade no ICMS Comparação com o IVA Europeu. In: COELHO, Sacha Calmon Navarro et al. Temas de Direito Tributário: I Congresso Nacional da Associação Brasileira de Direito Tributário. Belo Horizonte: Livraria Del Rey, 1998, p. 122-123

30 TORRES, Ricardo Lobo. O princípio da não-cumulatividade e o IVA no Direito Comparado. In: MARTINS, Ives Gandra da Silva (Coord.). O Princípio da não-cumulatividade. São Paulo: Revista dos Tribunais; Centro de Extensão Universitária, 2004, p. 161.

31 DERZI, op. cit., p. 122. 
aos tributos no Estado de destino, livres de impostos, em absoluta igualdade de condições com os bens nele produzidos.

Neste caso, é necessária a aplicação de medidas compensatórias no país de destino, com o objetivo de onerar os bens e serviços importados na mesma medida em que são onerados os bens e serviços produzidos internamente, equalizando-se a carga fiscal das duas situações. ${ }^{32}$ Dessa forma, independentemente de sua origem, os bens e serviços deverão ser igualmente tratados, permitindo que os Estados estabeleçam com maior flexibilidade as suas alíquotas internas.

José Roberto Rodrigues Afonso e Érika Amorim Araújo ${ }^{33}$ resumem:

Quando esse princípio é utilizado, os tributos são cobrados no local onde as mercadorias são consumidas, as exportações são desoneradas no país de origem e o país importador tributa as aquisições externas segundo as mesmas regras aplicadas aos produtos domésticos. Dessa forma, pelo menos no que diz respeito aos motivos essencialmente tributários, assegura-se indiferença entre mercadorias similares fabricadas em distintos países.

Especificamente no caso do Brasil, Guilherme Della Garza Ronzani ${ }^{34}$ destaca que a adoção do princípio da tributação no destino não contribui na realização de justiça fiscal, pois, além de provocar uma ruptura no contexto necessário a uma Federação equilibrada, com unidade de mercado, sem barreiras à circulação de bens e serviços, penaliza os Estados-membros produtores e exportadores para os demais com a diminuição de sua receita.

Este efeito estimula a sonegação fiscal com a adoção de operações interestaduais fictícias, exigindo um sistema de físcalização complexo e custoso para a administração

32 COSTA, Alcides Jorge. ICM na Constituição e na Lei Complementar. São Paulo: Resenha Tributária, 1979 , p. 42.

33 AFONSO, José Roberto Rodrigues; ARAÚJO, Érika Amorim. Pós-Constituinte e Impostos Indiretos: Deformar ou Reformar? In: PINTO, Márcio Percival Alves; BISOTO JR., Geraldo (Orgs.). Política Fiscal e Desenvolvimento no Brasil. Campinas, SP: Unicamp, 2006, p. 294.

34 RONZANI, Guilherme Della Garza. Princípios da Tributação na Origem e da Tributação no Destino no Contexto da 'Guerra Fiscal'. In: SILVA, Paulo Roberto Coimbra; BERNARDES, Flavio Couto; FONSECA, Maria Juliana (Coords.). Tributação sobre o Consumo. São Paulo: Quartier Latin, 2008, p. 199 
tributária, além de desestimular o relacionamento entre os Estados federados, já afetado pelas disparidades socioeconômicas.

Nesse contexto, o autor conclui que o princípio da tributação no destino não é capaz de reduzir a guerra fiscal, que será tratada no presente trabalho, devendo-se estudar a possibilidade de manter a tributação na origem, com a adoção de aperfeiçoamentos, tais como a repartição de receitas concomitantemente com a diferenciação de alíquotas. ${ }^{35}$

35 RONZANI, Guilherme Della Garza. Princípios da Tributação na Origem e da Tributação no Destino no Contexto da 'Guerra Fiscal'. In: SILVA, Paulo Roberto Coimbra; BERNARDES, Flavio Couto; FONSECA, Maria Juliana (Coords.). Tributação sobre o Consumo. São Paulo: Quartier Latin, 2008, p. 200. 


\section{PRINCÍPIOS INFORMADORES DA TRIBUTAÇÃO SOBRE O CONSUMO}

\subsection{Princípio da Igualdade E JuStiÇA Fiscal na Tributação}

Com a organização dos indivíduos em sociedade, surgiu o Estado. O nascimento da responsabilidade do Estado pela organização da sociedade gerou a necessidade de este obter recursos para suportar os encargos despendidos com as suas novas funções: segurança, educação, saúde, administração, distribuição da Justiça, etc.

O cumprimento destas obrigações representa custos para a sociedade, uma vez que deverão ser financiadas por seus membros.

Surge, então, a necessidade de definir a forma como os indivíduos devem contribuir, para que o Estado que integram realize as atividades que lhe são imputadas.

Uma das formas mais importantes para que os Estados obtenham receitas necessárias e suficientes à sua manutenção e ao correto exercício de suas funções é a tributação: "Pela tributação o Estado exige, coercitivamente, o pagamento de determinadas quantias pelos membros da sociedade com o objetivo de arrecadar o necessário para o financiamento de seus gastos." 36

A cobrança do tributo, então, se justifica pela necessidade do Estado de estar em condições de satisfazer às necessidades públicas.

Nesse sentido, Vanoni esclarece:

O Estado exerce uma atividade orientada no sentido de obtenção de determinados fins, que são fins de interesse geral cuja realização resolvese em benefício da coletividade. A cargo de todos quantos pertençam ao grupo estatal, e que portanto tenham interesse na atividade deste, surge

36 CONTI, José Mauricio. Princípios Tributários da Capacidade Contributiva e da Progressividade. São Paulo: Dialética, 1996, p. 11. 
um dever moral, antes mesmo que jurídico, de concorrer para fazer frente aos encargos públicos. O legislador, com base nos princípios políticos, econômicos, éticos, que prevalecem ao tempo, disciplinará de maneira concreta a repartição no montante necessário entre os obrigados, mas o dever do indivíduo de suportar o tributo, e o direito do Estado de exigi-lo, já se terão afirmado em abstrato no próprio momento em que o Estado, organizando-se, tenha começado a exercer uma atividade orientada para finalidade de natureza pública. ${ }^{37}$

O dever dos súditos de contribuir para com o Estado, por meio de tributos, para que este exerça adequadamente suas funções, ganhou notoriedade no Iluminismo, a partir da obra de Adam Smith.

Passou-se a ser necessária, então, a definição dos critérios e princípios que suportariam a exigência dos tributos, ou seja, definir a oportunidade e a medida de cobrança.

Nesse contexto, é importante destacar que a exigência de tributos deve sempre perseguir uma justiça fiscal, ou seja, deve ser feita de forma justa, em que exista uma adequada distribuição do ônus tributário entre os indivíduos.

O conflito entre eficiência arrecadatória e justiça fiscal não pode ser desprezada no âmbito da tributação sobre o consumo. ${ }^{38}$

E a justiça fiscal, dentro de uma estrutura de um sistema tributário ideal, relacionase com equidade, igualdade e proporcionalidade.

Ao tratar da justiça fiscal, Klaus Tipke sustenta que no Estado de Direito as leis, especialmente as tributárias, devem ser materialmente justas, fundando-se na igualdade, que exige que a carga tributária seja distribuída igualmente pela sociedade, no Estado Social, que impõe que os indivíduos mais abastados contribuam proporcionalmente mais

37 VANONI, Ezio. Natureza e Interpretação das Leis Tributárias. Trad. Rubens Gomes de Sousa. Rio de Janeiro: Edições Financeiras S/A, 1932, p. 125.

38 TEIXEIRA, Alessandra Machado Brandão. A Tributação sobre o Consumo de Bens e Serviços. Belo Horizonte: Mandamentos, 2002, p. 184. 
que os indivíduos que possuem menos recursos, e na liberdade, que limita a imposição tributária. $^{39}$

Assim, para que se obtenha uma estrutura tributária ideal, observando-se justiça fiscal, igualdade, equidade e proporcionalidade, mister se faz que se utilize um critério adequado de comparação para o tratamento isonômico com fundamento na justiça.

\subsubsection{Princípio da Capacidade Contributiva e a Tributação sobre o CONSUmo}

A origem do princípio da capacidade contributiva é atribuída a Adam Smith em sua obra Riqueza das Nações, embora antes mesmo já se tenha registro da adoção do princípio. $^{40}$

De acordo com o referido princípio, os cidadãos são tributados de acordo com a sua capacidade de contribuir com o Estado, de forma que os contribuintes que apresentam maior capacidade devem arcar com um ônus tributário mais elevado. Ou seja, quanto maior for a capacidade de suportar o ônus tributário, maior deve ser sua contribuição.

Nas palavras de Dino Jarach, capacidade contributiva

É a potencialidade de contribuir como os gastos públicos que o legislador atribui ao sujeito passivo particular. Significa ao mesmo tempo existência de uma riqueza em posse de uma pessoa ou em movimento entre duas pessoas e graduação de obrigação tributária, segundo a magnitude da capacidade contributiva que o legislador lhe atribui. ${ }^{41}$

39 TIPKE, Klaus; YAMASHITA, Douglas. Justiça Fiscal e princípio da capacidade contributiva. São Paulo: Malheiros, 2002, p. 17.

40 CONTI destaca que, (i) em Atenas, já há registro de um imposto exigido em quatro categorias, no tempo de Sólon, considerando-se a fortuna do contribuinte, (ii) em Roma, foi exigido um imposto denominado Soberbo, que tinha como fundamento a fortuna de cada contribuinte, e (iii) Tomas de Aquino, na Idade Média, já manifestava seu entendimento de que cada um deveria pagar tributos secundum facultatem ou secundum equalitem proportionis (CONTI, José Mauricio. Princípios Tributários da Capacidade Contributiva e da Progressividade. São Paulo: Dialética, 1996, p. 37).

41 JARACH, Dino. O fato imponível: Teoria Geral do Direito Tributário Substantivo. Trad. Dejalma de Campos. São Paulo: Revista dos Tribunais, 1989, p. 97. 
Fernando Zilveti destaca que

[...] isto significa que os custos públicos devem ser rateados proporcionalmente entre os cidadãos, na medida em que estes tenham usufruído da riqueza garantida pelo Estado. Também aceita como capacidade contributiva, a divisão eqüitativa das despesas na medida da capacidade individual de suportar o encargo fiscal. ${ }^{42}$

Dessa forma, tem-se que capacidade contributiva se resume como capacidade econômica de pagar o tributo, ter riqueza suficiente para contribuir com as despesas do Estado.

É importante ressaltar que a doutrina distingue as expressões capacidade contributiva, capacidade econômica e capacidade financeira.

Resumidamente, afirma-se que capacidade financeira é a disponibilidade do indivíduo para liquidação das obrigações, em geral na forma em que contratadas. Capacidade econômica é a aptidão dos indivíduos de obter riquezas. Por sua vez, capacidade contributiva refere-se especificamente à capacidade do indivíduo de arcar com a imposição especifica ou global, ou seja, é a "dimensão econômica particular de sua vinculação ao poder tributante, nos termos da lei" ${ }^{, 43}$.

Assim, a capacidade contributiva seria espécie de capacidade financeira/econômica, representando a manifestação de potencialidade de riqueza do indivíduo que pode se sujeitar ao poder tributante.

Pode-se classificar a capacidade contributiva em relativa ou subjetiva e absoluta ou objetiva.

42 SCHOUERI, Luis Eduardo. Normas Tributárias Indutoras e Intervenção Econômica. Rio de Janeiro: Forense, 2005, p. 282.

43 CONTI, José Mauricio. Princípios Tributários da Capacidade Contributiva e da Progressividade. São Paulo: Dialética, 1996, p. 35. 
No primeiro caso, a parcela da riqueza a ser tributada observa as condições individuais do contribuinte, podendo-se afirmar que a capacidade contributiva atua como critério de graduação e limite do tributo. Regina Helena Costa afirma:

A capacidade contributiva relativa ou subjetiva, por seu turno, opera, inicialmente, como critério de graduação dos impostos. Como ver-se-á adiante, quando cuidarmos especificamente da definição da base de cálculo e da alíquota, a apuração do quantum do imposto tem como medida a própria capacidade contributiva do sujeito passivo. ${ }^{44}$

Já na segunda situação, a capacidade contributiva é vista como pressuposto da tributação, em que se apura uma riqueza apta a ser objeto de tributação. Aqui, Regina Helena Costa resume:

A capacidade contributiva absoluta ou objetiva funciona como pressuposto ou fundamento jurídico do tributo, ao condicionar a atividade de eleição, pelo legislador, dos fatos que ensejarão o nascimento de obrigações tributárias. Representa sensível restrição à discrição legislativa, na medida em que não autoriza, como pressuposto de impostos, a escolha de fatos que não sejam reveladores de alguma riqueza. $^{45}$

Questão primordial a se definir é a da medição da capacidade contributiva, significa dizer, como determinar quem tem capacidade contributiva?

Conti $^{46}$ destaca que a importância da definição do critério escolhido está relacionada com o fato de que os critérios eleitos deverão integrar a hipótese de incidência do tributo. Tais critérios determinarão o fato indicador de riqueza selecionado pelo legislador para ser objeto de tributação.

Há três critérios indicativos de capacidade contributiva que podem ser utilizados como fundamento para a tributação: a) renda auferida, b) renda despendida (consumo) e c) renda acumulada (patrimônio).

44 COSTA, Regina Helena. Princípio da Capacidade Contributiva. São Paulo: Malheiros, 1993, p. 25.

45 Ibid., p. 23.

46 CONTI, José Mauricio. Princípios Tributários da Capacidade Contributiva e da Progressividade. São Paulo: Dialética, 1996, p. 41. 
Klaus Tipke e Joachim Lang assim se manifestam sobre os referidos critérios:

Cada um dos indicadores 'renda', 'patrimônio' e 'consumo' é por cada tributo onerado: um tributo sobre a renda não reduz somente a renda, mas da mesma forma também as possibilidades de consumo do contribuinte. Um tributo sobre o consumo onera não somente o consumo, mas em seguida também a renda, enquanto ele onera a utilização da renda. E cada tributo é afinal satisfeito com um (sob condições financiado por outrem) patrimônio. $^{47}$

Nessa linha, o autor destaca que a circunstância de que cada tributo onera renda, patrimônio e consumo permite diferentes avaliações não apenas da justificação de tributos, mas também dos efeitos que tais indicadores têm sobre o sistema tributário. ${ }^{48}$ Assim, a utilização por um Estado de determinado critério mensurador da capacidade contributiva deve considerar os efeitos tributários econômicos de cada tributo em consonância com as necessidades de sua sociedade.

A renda auferida ainda é considerada como a melhor forma de aferir a capacidade contributiva e de impor a tributação. Em sua defesa, afirma-se tratar-se de critério abrangente, que inclui todas as receitas auferidas ou utilizadas por um indivíduo.

Há, ainda, em sua vantagem, a praticabilidade de sua aplicação, por se tratar de tributação direta, possibilitando estabelecer alíquotas diferenciadas de acordo com a intenção de onerar mais ou menos os indivíduos, o que não é possível na tributação sobre o consumo. $^{49}$

Para aqueles que defendem a tributação sobre o consumo como melhor alternativa para apurar a capacidade contributiva, argumenta-se que a imposição tributária sobre os gastos do contribuinte visa à penalização do indivíduo pelo seu consumo, que se caracterizaria como ato egoísta e antissocial, enquanto a poupança e o investimento seriam

47 TIPKE, Klaus; LANG, Joachim. Direito Tributário. Porto Alegre: Sergio Antonio Fabris, 2008, p. 210.

48 Ibid., p. 211.

49 CONTI, José Mauricio. Princípios Tributários da Capacidade Contributiva e da Progressividade. São Paulo: Dialética, 1996, p. 42-43. 
vistos como atos benéficos, passíveis de incentivos e que, portanto, não poderiam ser penalizados pela tributação. ${ }^{50}$

Utiliza-se, ainda, em defesa da tributação sobre o consumo, o argumento de que a tributação sobre a renda auferida poderia ser considerada como uma bitributação da poupança, na medida em que se estaria tributando o consumo e a poupança do indivíduo que auferiu essa renda.

Por último, a tributação do patrimônio é defendida pelo argumento de que os bens podem gerar renda (renda auferida a partir do capital) e que, dessa forma, a tributação se justificaria sobre a presumível renda que se poderia obter a partir desta riqueza, o patrimônio. $^{51}$

Tem-se, portanto, que todos os três critérios são legítimos, devendo cada Estado eleger o(s) seu(s) para mensurar a capacidade contributiva de acordo com os efeitos econômicos que se pretende obter com a tributação:

Sendo dado valor em uma alta medida à redistribuição, ao nivelamento de rico e pobre, à distribuição igualitária do capital nacional, deve a parte do Estado ser captada o mais cedo possível, antes do consumo, portanto nos momentos em que surge o patrimônio ou ainda não foi utilizado (conceito da assim chamada imposição orientada pelo capital). Deve entretanto a sociedade ser concebida o quanto possível liberal e individualista segundo o princípio da subsidiariedade e acima de tudo ser atribuída ao cidadão a responsabilidade por seu bem estar e 'pursuit of happiness', aí então deve o Estado esperar, até que o cidadão consuma. A intervenção fiscal deve portanto o mais tarde possível ser fixada (assim o conceito da assim chamada interposição orientada pelo consumo) ${ }^{52}$

Considerando que a capacidade contributiva é um critério jurídico para se instituir uma tributação justa, idônea para exprimir a potencionalidade de suportar o ônus tributário, é ainda importante mencionar que há dois limites a serem respeitados para que não se aniquile essa capacidade: o mínimo vital e o não confisco.

50 CONTI, José Mauricio. Princípios Tributários da Capacidade Contributiva e da Progressividade. São Paulo: Dialética, 1996, p. 42-43.

51 Ibid., loc. cit.

52 TIPKE, Klaus; LANG, Joachim. Direito Tributário. Porto Alegre: Sergio Antonio Fabris, 2008, p. 211. 
Mínimo vital ou existencial, nas palavras de Fernando Zilveti, “é a menor quantia de renda absolutamente necessária para a sobrevivência digna do contribuinte" ${ }^{\text {"53 }}$. Nessa linha, esclarece que o Estado não pode instituir tributação que ofenda os direitos fundamentais do cidadão, tais como, direito à alimentação, saúde, educação, habitação, exercício profissional etc.

Assim, tendo em vista que estes recursos, destinados às necessidades básicas, não são reveladores de capacidade contributiva, não se permite que sejam atingidos pela tributação, pois, caso contrário, estar-se-ia atingindo alguém sem capacidade contributiva.

Dessa forma, a tributação só pode incidir sobre o que excede o mínimo vital, não se podendo tributar os valores que são necessários à manutenção individual e da família.

Destaque-se, entretanto, que a fixação do mínimo vital é variável em função do conceito de necessidades básicas de cada sociedade, tratando-se de decisão política do legislador a sua determinação.

Também não pode a tributação ter efeito confiscatório, uma vez que, assumindo esse caráter, a tributação estaria atingindo valor que excede a capacidade contributiva.

Conti destaca que pode se considerar como "confiscatório o tributo que atinja o contribuinte, de tal forma que venha a violar seu direito de propriedade sem a correspondente indenização" ${ }^{, 54}$.

Ou seja, os tributos não podem atingir o direito de propriedade dos indivíduos.

Considerando o caráter pessoal do princípio da capacidade contributiva, questionase a sua aplicação aos denominados impostos indiretos, entre eles os que incidem sobre o consumo de bens e serviços.

53 ZILVETI, Fernando Aurelio. Princípios de Direito Tributário e a Capacidade Contributiva. São Paulo: Quartier Latin, 2004, p. 203.

54 CONTI, José Mauricio. Princípios Tributários da Capacidade Contributiva e da Progressividade. São Paulo: Dialética, 1996, p. 55. 
Nos termos anteriormente expostos, os impostos indiretos são aqueles em que o ônus tributário não é suportado pelo contribuinte de direito, que tem a obrigação de pagar o tributo, mas pelo contribuinte de fato, que efetivamente é quem suporta o ônus do tributo, pelo fenômeno da repercussão.

Dessa forma, tendo em vista que a capacidade contributiva caracteriza-se como o atributo de o sujeito passivo da obrigação suportar o ônus tributário, afirma-se que nos impostos indiretos não é possível identificar essa capacidade, na medida em que as condições pessoais do contribuinte de fato, que efetivamente suporta o ônus do tributo, seriam desconhecidas.

No entanto, a tese de que a capacidade contributiva não seria aplicável aos impostos indiretos é afastada, sob o argumento de que é possível, ainda que indiretamente, aplicar o princípio aos referidos impostos. ${ }^{55}$

É o caso, por exemplo, da adoção da essencialidade do produto, que será a seguir abordada, de modo a não se tributarem os produtos destinados a atender necessidades básicas dos indivíduos. ${ }^{56}$

Ademais, conforme já exposto acima, o consumo e o patrimônio também são meios legítimos para apurar a capacidade econômica do contribuinte. Dessa forma, considerandose que os impostos indiretos atingem a renda consumida e a renda poupada, considerados como índices válidos de mensuração da capacidade contributiva, ao lado da renda auferida, é lógico afirmar que referidos impostos devem observar o princípio em questão:

Tanto o consumo como a riqueza, além da renda, são índices reveladores da capacidade contributiva e não devem ser desprezados. Assim sendo, todos os impostos sujeitam-se ao princípio da capacidade contributiva e não devem ser desprezados. ${ }^{57}$

55 CONTI, José Mauricio. Princípios Tributários da Capacidade Contributiva e da Progressividade. São Paulo: Dialética, 1996, p. 66-67.

56 Ibid., loc. cit.

57 Ibid., p. 67. 
Alessandra Machado Brandão Teixeira ${ }^{58}$ destaca três correntes sobre a identificação da capacidade contributiva na tributação sobre o consumo.

A primeira corrente afirma que a capacidade contributiva observada pela tributação sobre o consumo é a dos contribuintes de direito.

Contribuintes de direito são os agentes econômicos que promovem a produção e comercialização de bens e serviços que sofrem os efeitos imediatos da norma jurídica tributária.

Em razão da própria sistemática de incidência da tributação sobre o consumo e considerando que os contribuintes de direito, na medida do possível, respeitando-se a elasticidade da demanda e da oferta do produto, repassam o ônus tributário no preço do produto para os contribuintes de fato, não se pode afirmar que a capacidade contributiva visada pela tributação é a desses agentes, já que seu patrimônio não será atingido por essa forma de incidência tributária. ${ }^{59}$

Ademais, a Autora destaca que o exercício de atividade econômica pelos contribuintes de direito não lhes confere demonstração de capacidade contributiva para a imposição de tributação do consumo. Mesmo porque a atividade comercial é atingida pela tributação sobre a renda, quando apurado lucro. ${ }^{60}$

Em uma segunda corrente, entende-se que é a capacidade contributiva dos contribuintes de fato que é atingida pela tributação pelo consumo.

Tendo em vista que a capacidade contributiva na tributação sobre o consumo se implementa através da seletividade, afirma-se que devem se considerar as características do contribuinte de fato, já que, para a seletividade, as características do contribuinte de direito são irrelevantes.

58 TEIXEIRA, Alessandra Machado Brandão. A Tributação sobre o Consumo de Bens e Serviços. Belo Horizonte: Mandamentos, 2002, p. 231.

59 Ibid., p. 232.

60 Ibid., p. 233. 
Dessa forma, considerando-se a seletividade e, ainda, o fato de que, pela sistemática da tributação sobre o consumo, o encargo financeiro é repassado ao consumidor final, forçoso concluir que a capacidade contributiva atingida é a desse sujeito:

Em se tratado de tributação sobre o consumo, deve-se ter em consideração que o que se procura tributar são os valores disponibilizados pelos cidadãos para o consumo de bens e serviços. Quando esses consomem determinadas mercadorias ou serviços, eles manifestam uma capacidade contributiva passível de tributação. ${ }^{61}$

O último posicionamento defende que a própria operação denota a capacidade contributiva a ser alcançada pela tributação.

Nessa linha, afirma-se que os sujeitos passivos da incidência são os contribuintes de direito, não havendo relação dos contribuintes de fato com o Fisco. Ademais, há incidência tributária também quando o adquirente é um sujeito passivo. ${ }^{62}$

Dessa forma, sustenta-se que, sendo irrelevante a destinação do bem ou do serviço ao consumidor final, já que há tributação em todas as fases de produção e da comercialização de bens e serviços, considera-se a circulação de mercadorias e serviços como fato indicador de capacidade contributiva, referida a ambos os sujeitos envolvidos na operação (contribuinte de direito e de fato). ${ }^{63}$

Assim, a seletividade estaria relacionada com a própria operação. Alessandra Machado Brandão Teixeira exemplifica que a menor tributação do arroz não visaria ao consumidor final do produto, mas à sua própria operação de venda. ${ }^{64}$

No entanto, a tributação reduzida do arroz é baseada na premissa de que se trata de produto de primeira necessidade, tanto para ricos quanto para pobres:

61 TEIXEIRA, Alessandra Machado Brandão. A Tributação sobre o Consumo de Bens e Serviços. Belo Horizonte: Mandamentos, 2002, p. 234.

62 Ibid., loc. cit.

63 Ibid., p. 235.

64 Ibid., p. 236. 
Através da aplicação de alíquotas menores às vendas de produtos essenciais à existência humana é garantida a proteção ao mínimo vital anteriormente mencionado. Então, o que se atinge não é a operação em si, mas a manifestação de riqueza denotada pelo consumo, ora de bens vitais, aplicando-se alíquotas reduzidas, ora de bens supérfluos, sobretaxando as operações. ${ }^{65}$

Concluímos, então, que a tributação sobre o consumo deve observar a capacidade contributiva do contribuinte de fato.

Por fim, é importante destacar que, embora a capacidade contributiva seja conceituada como capacidade econômica de pagar o tributo, independentemente de uma contraprestação do Estado, recentemente, com a retomada da ideia de solidariedade, retomou-se a teoria do benefício para legitimar a capacidade contributiva, como fundamento ético da própria tributação.

Conforme destaca Ricardo Lobo Torres, de acordo com esta teoria, o "imposto não deve ser exigido sem a contrapartida do Estado, em termos genéricos, na garantia dos direitos fundamentais e sociais" $" 66$.

Retorna-se aqui a ideia do liberalismo de que o imposto é o preço da segurança e da liberdade, sendo que o imposto deve corresponder a uma oferta/demanda de bens e serviços públicos, em igualdade com a de bens e serviços privados.

Ou seja, ainda que não ligada a uma contraprestação específica para a cobrança do imposto, há a ideia de que o Estado deve fornecer algo para o contribuinte (segurança/liberdade), que tem o dever de contribuir com base na solidariedade social:

A solidariedade entre os cidadãos deve fazer com que a carga tributária recaia sobre os mais ricos, aliviando-se a incidência sobre os mais pobres e dela dispensando os que estão abaixo do nível mínimo de sobrevivência. É um valor moral legitimador, que fundamenta a capacidade contributiva e que sinaliza para a necessidade de correlação

65 TEIXEIRA, Alessandra Machado Brandão. A Tributação sobre o Consumo de Bens e Serviços. Belo Horizonte: Mandamentos, 2002, p. 236.

66 TORRES, Ricardo Lobo. Tratado de Direito Constitucional Financeiro e Tributário - Valores e Princípios Constitucionais Tributários. Rio de Janeiro: Renovar, 2005, p. 300. 
entre direitos e deveres fiscais; mas não constitui ela própria uma regra ética juridicamente eficaz. ${ }^{67}$

\subsubsection{Seletividade como Mecanismo Para Implementar o Princípio da Capacidade Contributiva na Tributação sobre o Consumo}

Os impostos seletivos impõem forma de tributação que distingue mercadorias e serviços em virtude de sua essencialidade, para aplicação de tributação diversificada, constituindo, assim, um instrumento de extrafiscalidade. ${ }^{68}$

Carrazza $^{69}$ destaca que os impostos seletivos não apenas podem, mas, na verdade, devem ser utilizados como instrumento de política econômica e fiscal, estimulando a prática de operações ou prestações consideradas úteis ou convenientes ao Estado e, em contrapartida, onerando outras que não sejam consideradas tão úteis ou convenientes.

Dessa forma, as mercadorias e serviços básicos, assim considerados aqueles de primeira necessidade, são menos onerados, enquanto as mercadorias e serviços tidos por supérfluos estão sujeitos a uma tributação mais acentuada.

Verifica-se, pois, estar a seletividade intrinsecamente relacionada com a essencialidade da mercadoria ou do serviço.

Essencialidade, nas palavras de BALEEIRO:

[...] refere-se à adequação do produto à vida do maior número dos habitantes do País. As mercadorias essenciais à existência civilizada deles devem ser tratadas mais suavemente ao passo que as maiores alíquotas

67 TORRES, Ricardo Lobo. Tratado de Direito Constitucional Financeiro e Tributário - Valores e Princípios Constitucionais Tributários. Rio de Janeiro: Renovar, 2005, p. 301.

68 É considerada extrafiscalidade a função regulatória dos tributos. Extrafiscalidade é a utilização de tributos para fins ordinatórios, visando à indução de comportamentos dos contribuintes no sentido de deixar de fazer ou fazer algo. Afirma-se que um tributo tem função extrafiscal quando sua incidência tem como objetivo induzir comportamentos: "Se, com a imposição, não se deseja arrecadar, mas estimular ou desestimular certos comportamentos, por razões econômicas, sociais, de saúde etc., diz que o tributo tem finalidades extrafiscais ou regulatórias". (AMARO, Luciano. Direito Tributário Brasileiro. 10. ed. atualizada. São Paulo: Saraiva, 2004, p. 89).

69 CARRAZZA, Roque Antonio. ICMS. 15. ed., rev. e ampl. até a EC 67/2011, de acordo com a Lei Complementar 87/1996 com suas ulteriores modificações. São Paulo: Malheiros, 2011, p. 489-490. 
devem ser reservadas aos produtos de consumo restrito, isto é, o supérfluo das classes de maior poder aquisitivo. Geralmente são os artigos mais raros e, por isso, mais caros. Do ponto de vista econômico, a norma inspira-se na utilidade marginal. Do ponto de vista político, reflete as tendências democráticas e até mesmo socialistas do mundo contemporâneo no qual os países civilizados seguem orientação idêntica. $^{70}$

Tilbery $^{71}$ também tratou da essencialidade nos seguintes termos:

12.6 - o conceito de 'essencialidade' não deve ser interpretado estritamente para cobrir apenas as necessidades biológicas (alimentação, vestuário, moradia, tratamento médico), mas deve abranger também aquelas necessidades que sejam pressupostos de um padrão de vida mínimo decente, de acordo com o conceito vigente da maioria.

12.7 - Consequentemente, os fatores que entram na composição das necessidades essenciais variam de acordo com o espaço (conforme países e regiões) e o tempo (grau de civilização e tecnologia).

$[\ldots]$

12.9 - Em um país, que se encontra em fase avançadíssima de desenvolvimento, como é o caso do Brasil, a imposição seletiva sobre o consumo em função da essencialidade é um instrumento para frenar o consumo de produtos indesejáveis ou ao menos necessários, para liberar forças para investimentos merecedores de apoio, e, ao mesmo tempo, constitui instrumentalidade para nivelar diferenças excessivas no consumo de diversas classes em diversificadas zonas e alcançar a meta de redistribuição de rendas e maior aproximação da Justiça Fiscal.

Nesse contexto, Melo $^{72}$ conclui que a essencialidade é o critério para aplicação de alíquotas diferenciadas às diversas espécies de mercadorias e serviços.

Carrazza $^{73}$ destaca que a aplicação da tributação seletiva deve diferenciar mercadorias e serviços, levando em consideração a sua natureza, sendo irrelevante como fator de discriminação fatores como raça, sexo, ocupação profissional etc., sob pena de

70 BALEEIRO, Aliomar. Direito tributário brasileiro. Atualizada por Misabel Abreu Derzi. Rio de Janeiro: Forense, 2005, p. 347-348.

71 TILBERY, Henry. O conceito de essencialidade como critério de tributação. Direito Tributário Atual. São Paulo: IBDT; Resenha Tributária, v. 10, p. 2969-3031, 1990.

72 MELO, José Eduardo Soares de. ICMS - Teoria e Prática. 9. ed. São Paulo: Dialética, 2006, p. 288.

73 CARRAZZA, Roque Antonio. ICMS. 15. ed., rev. e ampl. até a EC 67/2011, de acordo com a Lei Complementar 87/1996 com suas ulteriores modificações. São Paulo: Malheiros, 2011, p. 492-493. 
ofensa ao disposto no artigo $5^{\circ}$, inciso I da Constituição Federal, bem como não pode ser levado em consideração a destinação ou origem do bem ou do serviço, a fase do ciclo de produção ou a condição econômica de quem adquire a mercadoria ou frui do serviço.

De qualquer forma, pode-se afirmar que, onerando de forma mais intensa as mercadorias e serviços considerados supérfluos, os impostos seletivos estão em consonância com o princípio da capacidade econômica, pois o adquirente de mercadoria ou serviço de luxo considerados supérfluos revela maior capacidade econômica, devendo, assim, ser proporcionalmente mais tributado do que o adquirente de bem ou serviço essencial. Nesse sentido, destaca-se que, no último caso, não há, de fato, mera liberdade de consumo, mas, tão-somente, necessidade, sendo imperioso que sobre estes bens se faça sentir um tratamento fiscal mais brando.

Luis Eduardo Schoueri ${ }^{74}$ destaca, entretanto, que há três posições referentes à resolução do conflito entre a capacidade contributiva e os princípios que amparam as normas com função extrafiscal, entre os quais se enquadra a seletividade do IPI e do ICMS.

O primeiro posicionamento destaca as dificuldades em adequar a tributação extrafiscal ao princípio da capacidade contributiva, pois o princípio impede, limita a utilização de um tributo com fins extrafiscais.

A segunda posição, da qual Schoueri cita os ensinamentos de Klaus Tipke e Ricardo Lobo Torres, sustenta que a extrafiscalidade não se submete ao princípio da capacidade contributiva, mas o princípio do Estado Social. Havendo, ainda, neste sentido, doutrinadores afirmando que, no caso de tributos extrafiscais, o princípio da capacidade contributiva pode ser excepcionado diante de outros critérios. ${ }^{75}$

74 SCHOUERI, Luis Eduardo. Normas Tributárias Indutoras e Intervenção Econômica. Rio de Janeiro: Forense, 2005, p. 278-280.

75 Ibid., p. 278-280. 
Nessa linha, afirma-se que, embora as normas indutoras com finalidades extrafiscais colidam com a capacidade contributiva, encontram fundamento em outros princípios constitucionais.

Destaque-se o entendimento de Fernando Zilveti, que, apesar de frisar que as normas indutoras devem respeitar o princípio da capacidade contributiva, bem como o da igualdade tributária, quando da sua aplicação instrumental na atividade de arrecadação do Estado, sustenta que a extrafiscalidade é desvinculada da capacidade contributiva, concluindo:

\begin{abstract}
Adota-se a melhor doutrina e jurisprudência, no sentido de que a extrafiscalidade não guarda relação com o princípio da capacidade contributiva. [...] Quais seriam, então, os limites da extrafiscalidade? Em linhas gerais pode-se aceitar que o limite é a justiça e a propriedade. Mais especificamente, alguns dos limites podem ser o respeito à propriedade $\mathrm{e}$ à liberdade do exercício profissional, direitos fundamentais previstos na Constituição de 1988 , no artigo $5^{\circ}$, respectivamente nos incisos XXII e XIII. Outro limite à extrafiscalidade, ou às normas indutoras em matéria fiscal é o direito constitucional ao não confisco, nos termos do artigo IV da Constituição Federal. ${ }^{76}$
\end{abstract}

Por fim, há a posição de que os tributos com fins extrafiscais são compatíveis com a capacidade contributiva. Schoueri adota esta corrente, afirmando que "as normas tributárias indutoras não perdem sua natureza tributária e por isso continuam sujeitas aos cânones tributários, cabendo daí ao jurista estudar sua compatibilidade tanto com o Direito Tributário como com o Direito Econômico". 77

Esta última posição parece ser adequada, pois, ainda que com fins de intervenção/indução e não arrecadatórios, tais normas não perdem sua natureza tributária e, por isso, devem respeitar todos os princípios e demais normas tributárias, mesmo que, em algumas situações, a observância de um princípio afaste parcialmente ou mitigue a aplicação de outro princípio. Este sopesamento de princípios, entretanto, não implica a afirmação de que um tributo é incompatível com o princípio que restou mitigado.

76 ZILVETI, Fernando Aurelio. Princípios de Direito Tributário e a Capacidade Contributiva. São Paulo: Quartier Latin, 2004, p. 197.

77 SCHOUERI, Luis Eduardo. Normas Tributárias Indutoras e Intervenção Econômica. Rio de Janeiro: Forense, 2005, p. 280-281. 
A Constituição Federal estabelece a aplicação obrigatória da seletividade para o IPI (artigo 153, $\S 3^{\circ}$, I) e facultativa para o ICMS (artigo 155, $\S 2^{\circ}$, III), em função da essencialidade do produto.

Conforme exposto acima, para parte da doutrina, a seletividade em função da essencialidade do produto impõe uma tributação mais gravosa aos bens considerados supérfluos e uma tributação menos onerosa aos produtos considerados essenciais.

De acordo com esta doutrina, a essencialidade para fins de seletividade do imposto pode ser considerada apenas levando em consideração a utilidade, finalidade e a necessidade do produto para consumo, não se podendo adotar outros critérios para instituir qualquer seletividade.

Paulo de Barros Carvalho ensina que a fixação das alíquotas seletivas, em função do grau de essencialidade dos produtos, utiliza a divisão dos produtos nas seguintes categorias: i) necessários à subsistência, alíquotas menores; ii) úteis, mas não necessários, alíquotas razoáveis e iii) produtos de luxo, alíquotas significativas. ${ }^{78}$

Realmente, considerando-se como determinado o conceito de "essencialidade" na forma exposta anteriormente, seria forçoso reconhecer que apenas a necessidade/utilidade/finalidade do produto poderia ser considerada como critério de discriminação para fixação de alíquotas pelo IPI e ICMS.

Todavia, é importante ressaltar que o texto da Constituição Federal não esclarece e não define o que se deve entender por essencialidade. Ademais, essencialidade não é um conceito determinado.

Nesse contexto, partindo da premissa de que a seletividade/essencialidade prevista na Constituição é um conceito indeterminado, Laís Vieira Cardoso esclarece que o conceito de seletividade, previsto para o IPI, não pode ser compreendido apenas em função

78 CARVALHO, Paulo de Barros. Introdução ao Estudo do Impôsto sobre Produtos Industrializados. Revista de Direito Público, São Paulo, v. 11, p. 75-85, 1969. 
das características específicas dos produtos. Considerando que o conceito de essencialidade não é determinado, ela afirma que o conceito abrange, ainda, a análise das necessidades de uma coletividade e os aspectos que giram em torno da economia adotada por aquele Estado-nação, aspecto amplo e que pode variar constantemente conforme as alterações que ocorrem neste mercado, atualmente globalizado. ${ }^{79}$

Ou seja, o conceito de essencialidade pode variar de acordo com diversos elementos referentes à comunidade e ao tempo em que esta sociedade se localiza, para fins extrafiscais e da intervenção econômica. Veja-se que para fins fiscais, meramente arrecadatórios, a "essencialidade" do produto deve levar em consideração tão-somente a necessidade e utilidade dos produtos, sendo qualquer outra diferenciação, para estes fins, inconstitucional.

Dessa forma, levando-se em conta que o termo essencialidade está previsto na Carta Magna de forma aberta, "podendo ser preenchido, a par das questões oriundas da justiça distributiva, igualmente por forças de ordem estrutural” ${ }^{, 80}$, pode-se afirmar que o conceito de "essencial" pode ser reformulado para se adequar às finalidades extrafiscais e de intervenção no domínio econômico, funções estas expressamente previstas para o IPI e para o ICMS, permitindo-se a interpretação do referido termo de forma não limitada à relação da essencialidade com a necessidade, finalidade e utilidade do produto.

Nesse sentido, vejam-se as conclusões de Luis Eduardo Schoueri:

Daí justificar-se, por conta das normas tributárias, que se reformule o conceito de "essencialidade", que deve ter duas perspectivas: o ponto de vista individual dos contribuintes e as necessidades coletivas. Sob a última perspectiva, tal conceito deve ser entendido a partir dos objetivos e valores constitucionais: essencial será o bem que se aproxime da concretização daqueles. Assim, tanto será essencial o produto consumido pelas camadas menos favorecidas da população, dado o objetivo fundamental da República de 'erradicar a pobreza e marginalização' (artigo $3^{\circ}$, III da Constituição Federal), como aquele que corresponda aos

79 CARDOSO, Lais Vieira. A Seletividade no IPI. In: PEIXOTO, Marcelo Magalhães (Coord.). IPI Aspectos Jurídicos Relevantes. São Paulo: Quartier Latin, 2003, p. 248.

80 SCHOUERI, Luis Eduardo. Normas Tributárias Indutoras e Intervenção Econômica. Rio de Janeiro: Forense, 2005, p. 301. 
auspícios da Ordem Econômica, diante do objetivo de 'garantir o desenvolvimento nacional', (artigo $3^{\circ}$, II). ${ }^{81}$

Ressalte-se que não se nega que a seletividade, segundo a essencialidade, deve observar a necessidade, finalidade e utilidade do produto, principalmente quando a fixação das alíquotas visa apenas atender aos objetivos fiscais do tributo. No entanto, quando as alíquotas do IPI e do ICMS são fixadas considerando os referidos impostos como instrumento de ordenação político-econômica, com o objetivo de estimular a prática de operações consideradas necessárias ou úteis à sociedade e não apenas do ponto de vista individual, e, em contrapartida, onerando outras que não atendem ao desenvolvimento e interesses sociais, também garantidos constitucionalmente, a "essencialidade" deve ser interpretada de forma ampla, que permita sejam atendidos os objetivos e valores previstos na Constituição Federal.

Outra utilidade de adoção de impostos seletivos é a possibilidade de corrigir externalidades, como nos casos dos impostos sobre combustíveis, álcool e fumo.

A justificativa para a tributação excessiva do álcool e do fumo, com a aplicação de alíquotas elevadas, está relacionada com os custos sociais e hospitalares do alcoolismo e pelos riscos para a saúde por causa do uso contínuo do fumo:

Estes custos não estão contabilizados nos preços de mercado e, portanto, conduzem a um excesso de consumo desses bens. Esse tipo de tributação pode ainda ser justificado com base na argumentação que define os bens meritórios. Estima-se que os usuários desses produtos, particularmente os jovens, não se dão conta dos impactos negativos, a longo prazo, sobre as condições de saúde, fazendo-se necessária a intervenção do governo por meio de tributação corretiva, para manter o consumo desses bens nos níveis socialmente ótimos. ${ }^{82}$

81 SCHOUERI, Luis Eduardo. Normas Tributárias Indutoras e Intervenção Econômica. Rio de Janeiro: Forense, 2005, p. 301.

82 SAMPAIO, Maria de Conceição. Tributação do consumo no Brasil: aspectos teóricos e aplicados. BIDERMAN, Ciro; ARVATE, Paulo (Orgs.). Economia do setor público no Brasil. Rio de Janeiro: Elsevier, 2004, p. 200. 
Ademais, nos Estados federados, é possível a aplicação de impostos seletivos em função da regionalidade, ou seja, a aplicação de tributação diferenciada de forma seletiva, considerando-se as disparidades inter-regionais, visando diminuí-las.

Os impostos seletivos podem ser empregados por diversas técnicas de alteração quantitativa da carga tributária, tais como sistema de alíquotas diferenciadas, variação da base de cálculo, criação de incentivos fiscais, etc.

\subsection{PRINCíPIOS DA UNIFORMIDAde E DA UNIDAdE ECONÔMICO-Política}

Conforme destacado por Luis Eduardo Schoueri, ao estabelecer as limitações ao poder de tributar, o Constituinte impôs restrições com o objetivo de evitar a ameaça à unidade do país em termos políticos e econômicos. ${ }^{83}$

O objetivo dessas limitações, ao proteger a liberdade de ir e vir, a liberdade de comércio e o federalismo, é garantir a unidade econômica e política do país.

O artigo 151, I, da Carta Magna determina ser vedado à União instituir tributo que não seja uniforme em todo o território nacional ou que implique distinção ou preferência em relação a Estado, Distrito Federal ou Município, em detrimento de outro, admitida a concessão de incentivos fiscais destinados a promover o equilíbrio do desenvolvimento socioeconômico entre as diferentes regiões.

É vedado, ainda, aos Estados, ao Distrito Federal e aos Municípios “estabelecer diferença tributária entre bens e serviços, de qualquer natureza, em razão de sua procedência ou destino" (artigo 152 da Constituição Federal).

Por fim, impede-se a limitação ao tráfego de pessoas ou bens, por meio de tributos interestaduais ou intermunicipais, ressalvada a cobrança de pedágio pela utilização de vias conservadas pelo Poder Público. (artigo 150, V da Constituição Federal).

83 SCHOUERI, Luis Eduardo. Direito Tributário. São Paulo: Saraiva, 2011, p. 324. 
Schoueri destaca que essas garantias estão em consonância com a proteção do mercado interno e com os princípios da soberania econômica e com o da livreconcorrência (artigo 219 e artigo 170, I e IV da Constituição Federal), ao prever, inclusive, uma exceção que visa à busca da unificação dos mercados:

Por outro lado, a busca de um mercado nacional único e indiferenciado tributariamente não fez o constituinte perder de vista o objetivo de redução de desigualdades regionais, cuidando, ele mesmo, de prever uma exceção à não-diferenciação, ao admitir no artigo 151, I, a "concessão de incentivos fiscais destinados a promover o equilíbrio do desenvolvimento socioeconômico entre as diferentes regiões do País". Tem-se, aqui, em matéria tributária, o reflexo do mandamento constitucional aplicável a toda intervenção sobre o Domínio Econômico, que se deve dirigir nos termos do "planejamento do desenvolvimento nacional equilibrado, o qual incorporará e compatibilizará os planos nacionais e regionais de desenvolvimento" (art. 174, I, da Constituição Federal). ${ }^{84}$

De fato, a previsão do artigo 151, I, confirma que as pessoas políticas são juridicamente iguais e que, por isso, devem se sujeitar à mesma tributação. Não obstante, reconhece ser necessária a possibilidade de concessão de incentivos fiscais para as pessoas políticas mais carentes, com o objetivo de promover o equilíbrio do desenvolvimento entre as diversas regiões. ${ }^{85}$

Carrazza destaca que esses incentivos, entretanto, não podem ser setoriais, ou seja, favorecer apenas determinadas categorias de pessoas, mas devem beneficiar a região como um todo. Ademais, devem favorecer as regiões menos desenvolvidas e que, de fato, necessitam de auxílio para prosperar. Não devem ser concedidos incentivos às regiões mais desenvolvidas. $^{86}$

O artigo 152 da Constituição Federal, por sua vez, garante que Estados, Municípios e Distrito Federal não concedam incentivos tributários sem critérios, mas, sim, observando o interesse público e promovendo o equilíbrio do desenvolvimento socioeconômico entre as regiões:

84 SCHOUERI, Luis Eduardo. Direito Tributário. São Paulo: Saraiva, 2011, p. 324.

85 CARRAZZA, Roque Antonio. Curso de Direito Constitucional Tributário. 19. ed., rev. e ampl. até a EC 39/2002. São Paulo: Malheiros, 2003, p. 768-769.

86 Ibid., loc. cit. 
Destarte, os Estados, os Municípios e o Distrito Federal não podem graduar, para mais ou para menos, seus tributos em razão da região de procedência ou destino dos bens e serviços de qualquer natureza. Melhor explicitando, a origem dos bens ou serviços ou o local para onde se destinam não autoriza a alteração das alíquotas ou das bases de cálculo dos tributos estaduais, municipais ou distritais. Em síntese, a Constituição proíbe que se erijam barreiras alfandegárias internas. Pelo contrário, ela quer que os bens e os serviços circulem livremente por todo o território nacional e - mais do que isso - que, saindo do Estado ou do Município de origem, possam concorrer, em clima de igualdade, com os bens e serviços locais. ${ }^{87}$

\subsection{PrincíPIO da NeUtralidade Fiscal}

Da mesma forma que a justiça fiscal, o princípio da neutralidade também tem como objetivo garantir ordem (consistência) e unidade (coerência) ao sistema jurídico tributário. $^{88}$

A justiça fiscal está associada à relação que se estabelece entre o cidadão e o Estado, buscando identificar a adequada contribuição do indivíduo para a manutenção da esfera pública de liberdade e igualdade. O princípio da justiça fiscal volta-se aqui à promoção do sentido público da tributação e de seus valores essenciais. ${ }^{89}$

O princípio da neutralidade fiscal, por seu turno, visa alcançar a correta correlação entre a tributação e a busca pela eficiência. ${ }^{90}$

Objetiva identificar em que medida a tributação se insere no contexto econômico e social, através da adequada correlação do contribuinte, visto como agente econômico, e a ordem econômica. O princípio da neutralidade fiscal, no sentido privado da tributação, como um valor essencial. ${ }^{91}$

87 CARRAZZA, Roque Antonio. Curso de Direito Constitucional Tributário. 19. ed., rev. e ampl. até a EC 39/2002. São Paulo: Malheiros, 2003, p. 770.

88 CALIENDO, Paulo. Direito Tributário e Análise Econômica do Direito: Uma visão crítica, Rio de Janeiro: Elsevier, 2009, p. 117.

89 Ibid., loc. cit.

90 Ibid., loc. cit.

91 Ibid., loc. cit. 
Há que se ponderar, entretanto, que determinadas medidas, embora atendam à justiça social, podem se caracterizar como soluções ineficientes no sistema econômico. Da mesma forma, uma medida economicamente eficiente, que resulte em uma maior prosperidade individual e coletiva, pode ofender a justiça fiscal. $\mathrm{O}$ sopesamento dos princípios e o seu conflito, conforme destaca Paulo Caliendo, não afeta a constatação de mútua importância, sendo necessária a busca de um equilíbrio dinâmico entre justiça e eficiência. $^{92}$

O princípio da neutralidade fiscal estabelece um valor ou fim: diminuir legitimamente os efeitos da tributação sobre a decisão dos agentes econômicos, de forma a evitar distorções e consequente ineficiência no sistema econômico. ${ }^{93}$

O grande desafio do Direito Tributário é alcançar um sistema tributário ideal, que cumpra com as suas funções de financiamento de políticas públicas, promoção dos direitos fundamentais, evitando ao máximo interferências nas decisões econômicas. ${ }^{94}$

O sentido da neutralidade fiscal está justamente na ideia de que a tributação tem como finalidade essencial estabelecer a exata parcela de contribuição do indivíduo à manutenção da esfera pública e não um mecanismo de intervenção econômica. ${ }^{95}$

A tributação deve ser o mais neutra possível, ou seja, não deve representar um elemento fundamental de decisão do agente econômico nas suas escolhas de investimento. Desse modo, a tributação não deve provocar a distorção do sistema econômico, de diminuição geral da eficiência e obstáculo ao desenvolvimento. ${ }^{96}$

Pelo princípio da neutralidade, o Estado não pode, por meio da tributação, criar condições de desigualdade entre os agentes econômicos, inibindo o acesso de alguns ao livre mercado, em benefício de outros.

92 CALIENDO, Paulo. Direito Tributário e Análise Econômica do Direito: Uma visão crítica, Rio de Janeiro: Elsevier, 2009, p. 117.

93 Ibid., p. 113.

94 Ibid., loc. cit.

95 Ibid., p. 117.

96 Ibid., p. 118. 
Quanto aos efeitos sobre a produção, um imposto é considerado neutro quando não induz os produtores a modificar os seus negócios de produção, ou seja, a forma como organizam os seus negócios e, quanto aos efeitos sobre o consumo, quando não leva os consumidores a modificar suas escolhas entre os diferentes bens que procuram. ${ }^{97}$

Xavier de Basto aborda a neutralidade, nos seguintes termos:

Um imposto de transações é neutro nos seus efeitos sobre a produção se não leva os produtores a modificar os seus métodos de produção, isto é, a forma como organizam os seus negócios; e diz-se neutro nos seus efeitos sobre o consumo se não conduz os consumidores a modificar as suas escolhas entre os diferentes bens que procuram. ${ }^{98}$

Rafael Triginelli Nery Miraglia afirma que a visão tradicional de neutralidade, relacionada com a preservação do estado das coisas (cristalização do status quo), pressupõe que as escolhas de mercado são naturalmente justas porque livres. Não se pode, assim, interferir no comportamento privado (produção ou consumo) por meio da tributação. As escolhas feitas na cadeia econômica de circulação devem ser preservadas e protegidas pelo Estado. ${ }^{99}$

José Luis Ribeiro Brazuna sintetiza o alcance do princípio da neutralidade na máxima da "leave-them-as-you-find-them rule of taxation"100.

Paulo Caliendo analisa o alcance do princípio da neutralidade sob três aspectos: sintático, semântico e pragmático. ${ }^{101}$

Estruturação sintática: análise do princípio sem considerar o seu conteúdo. Analisam-se a hierarquia das normas e as regras de estruturação. O princípio da

97 BASTO, José Guilherme Xavier de. A tributação do consumo e a sua coordenação internacional. Lisboa: Centro de Estudos Fiscais, 1991, p. 29.

98 Ibid., p. 29.

99 MIRAGILIA, Rafael Triginelli Nery. Neutralidade e Justiça Constitucional na Tributação do Consumo: princípio da não-cumulatividade em perspectiva. In: SILVA, Paulo Roberto Coimbra; BERNARDES, Flávio Couto; FONSECA, Maria Juliana. (Coords.). Tributação sobre o consumo. São Paulo: Quartier Latin, 2008, p. 353.

100 BRAZUNA, José Luis Ribeiro. Defesa da Concorrência e Tributação - À Luz do artigo 146-A da Constituição. São Paulo: Quartier Latin, 2009, p. 141.

101 Ibid., p. 114. 
neutralidade fiscal, considerado como fundamento de outras normas, atua como princípiogênero de onde outros princípios irão derivar: não cumulatividade, seletividade, uniformidade geográfica, liberdade de tráfego, etc. ${ }^{102}$

A seletividade é objeto de parâmetro de neutralidade, uma vez que objetiva preservar a neutralidade econômica sobre a renda das classes mais baixas, que possuem menor flexibilidade para os fenômenos de flutuação e crises de mercado. ${ }^{103}$

O princípio da uniformidade geográfica tem como objetivo impedir distorções decorrentes da alocação regional de recursos, com bases meramente fiscais, preservando, assim, de forma integrada, a neutralidade fiscal do mercado. ${ }^{104}$

Estruturação semântica: sob este aspecto, o princípio não prescreve uma determinada conduta, exprimindo apenas uma orientação de conduta. Estabelece a estrutura do sentido mínimo de uma norma, como esta deve ser construída. "Ele serve, nesse sentido, como forma de preenchimento de sentido de outras normas, tal como na concretização do princípio da não-cumulatividade, por exemplo. Assim, servirá como critério de aplicação, indicando os sentidos possíveis de serem adotados"105.

A determinação das regras para o aproveitamento de crédito do ICMS, com o objetivo de evitar a cumulatividade, é baseada na busca pela solução mais adequada ao princípio da neutralidade fiscal. ${ }^{106}$

Estruturação pragmática: o princípio figura como critério de decidibilidade na solução de conflitos. Determina o sentido das normas, funcionando como critério de decisão no âmbito judicial. ${ }^{107}$

102 BRAZUNA, José Luis Ribeiro. Defesa da Concorrência e Tributação - À Luz do artigo 146-A da Constituição. São Paulo: Quartier Latin, 2009, p. 114.

103 Ibid., loc. cit.

104 Ibid., loc. cit.

105 CALIENDO, Paulo. Direito Tributário e Análise Econômica do Direito: Uma visão crítica, Rio de Janeiro: Elsevier, 2009, p. 114-115.

106 Ibid., p.115. 
O Poder Judiciário, diante de interpretações diversas sobre determinada norma, deve adotar o entendimento que melhor se relaciona ao princípio da neutralidade fiscal, por exemplo, no caso de análise de aproveitamento de créditos de ICMS. ${ }^{108}$

Em suma, o princípio da neutralidade objetiva que se alcance um sistema em que os tributos não afetem o comportamento dos agentes econômicos.

No entanto, conforme destacado por Luis Eduardo Schoueri ${ }^{109}$ e José Luis Ribeiro Brazuna $^{110}$, essa visão de neutralidade acima descrita é utópica e irreal.

Primeiro porque a imposição tributária leva necessariamente aos fenômenos da repercussão econômica ou difusão, em conformidade com o grau de elasticidade da demanda ou da oferta do mercado sobre o qual recair. ${ }^{111}$

No caso de bem ou serviço com oferta elástica e demanda inelástica, o vendedor tem a possibilidade de repassar o encargo tributário para o comprador, pois poderá aumentar o preço, na medida do imposto incidente, sem que a quantidade demandada seja negativamente atingida. É possível o repasse integral, uma vez que o bem ou serviço não deixará de ser adquirido em razão de o preço ter aumentado. ${ }^{112}$

Os bens e serviços cuja oferta é inelástica e a demanda elástica não permitem o integral repasse do imposto para os compradores. Os vendedores têm que arcar com a maior parte do ônus tributário, pois, a qualquer aumento de preço, afeta a aquisição do bem ou do serviço. ${ }^{113}$

107 CALIENDO, Paulo. Direito Tributário e Análise Econômica do Direito: Uma visão crítica, Rio de Janeiro: Elsevier, 2009, p. 115.

108 Ibid. p. 116.

109 SCHOUERI, Luis Eduardo. Livre concorrência e tributação. In: ROCHA, Valdir de Oliveira (Coord.). Grandes questões atuais do Direito Tributário. v. 11, São Paulo: Dialética, 2007, p. 253.

110 BRAZUNA, José Luis Ribeiro. Defesa da Concorrência e Tributação - À Luz do artigo 146-A da Constituição. São Paulo: Quartier Latin, 2009, p. 141.

111 CALIENDO, op. cit., p. 141-142.

112 TEIXEIRA, Alessandra Machado Brandão. A Tributação sobre o Consumo de Bens e Serviços. Belo Horizonte: Mandamentos, 2002, p. 54.

113 Ibid., loc. cit. 
O ônus do imposto recai mais intensamente no lado do mercado, que é menos elástico, mas em qualquer cenário o imposto sempre repercutirá economicamente. Nesse sentido, Rubens Gomes de Souza conclui:

\begin{abstract}
Mas, mesmo simplificando o assunto ao mínimo essencial, temos de partir de um pressuposto certo, isto é, temos de nos guardar da falácia de que existem impostos "neutros", ou seja, impostos que geram receita sem produzir outros efeitos econômicos paralelos. Ora, que eu saiba, só Moisés tirou água de pedra, e isso mesmo porque Jeová deu uma mãozinha. Todo imposto é uma transferência de poder aquisitivo: de modo que aí já está o germe dos seus "outros" efeitos econômicos. ${ }^{114}$
\end{abstract}

Deve-se considerar, ademais, que os tributos não são utilizados pelo Estado apenas para a arrecadação de recursos a serem utilizados na manutenção das suas atividades. A tributação é utilizada também para fins indutores e a existência de normas tributárias com efeitos extrafiscais. A adoção das normas tributárias com essa finalidade afasta em definitivo a neutralidade fiscal, neste aspecto absoluto, pois a extrafiscalidade ou a indução necessariamente conduzem à interferência do tributo na economia. ${ }^{115}$

Fernando Zilveti destaca que o crescimento da adoção da tributação indutora ofusca a neutralidade, já que a indução, por impor a intervenção do Estado, é a antítese da neutralidade. ${ }^{116}$

Nesse contexto, se considerarmos a neutralidade como absoluta ausência de interferência da tributação sobre o livre funcionamento dos mercados, seria impossível falar em neutralidade fiscal na Constituição Federal, que contém permissões para a tributação extrafiscal ou indutora.

José Luis Ribeiro Brazuna destaca os ensinamentos de Fritz Neumark, que distinguiu de forma clara essa neutralidade fiscal liberal e utópica e a neutralidade perante o fenômeno concorrencial, por meio do qual ${ }^{117}$ :

114 SOUZA, Rubens Gomes de. Os impostos sobre o valor acrescido no sistema tributário. Revista de Direito Administrativo. Rio de Janeiro: FGV, n. 110, out./dez. 1972, p. 20.

115 BRAZUNA, José Luis Ribeiro. Defesa da Concorrência e Tributação - À Luz do artigo 146-A da Constituição. São Paulo: Quartier Latin, 2009, p. 141.

116 ZILVETI, Fernando Aurelio. Variações sobre o princípio da neutralidade no direito tributário internacional. Direito Tributário Atual, São Paulo: Dialética, v. 19, 2005, p. 26. 
i) deve-se evitar que a tributação interfira onde houver concorrência aproximadamente perfeita e cujos resultados não se contraponham as políticas econômicas e sociais do país ${ }^{118}$;

ii) deve-se lançar mão de políticas fiscais de estímulo à concorrência quando ela for imperfeita e, por conta disso, produzir efeitos indesejados do ponto de vista econômico. ${ }^{119}$

Fernando Zilveti conclui que o sistema tributário ideal seria aquele que alcançasse um menor grau de interferência e máximo de neutralidade, permitindo-se a atuação dos Estados para corrigir distorções ao princípio da neutralidade, em prejuízo à livreconcorrência. $^{120}$

No mesmo sentido, Luis Eduardo Schoueri afirma que a neutralidade não pode ser admitida como ausência total de interferência do tributo sobre a economia, mas como neutralidade da tributação com viés concorrencial:

Tem-se, pois, um sentido próprio para a neutralidade tributária, tendo em vista seu viés concorrencial: a norma tributária não deve afetar o mercado em sentido diverso daquele preconizado pelo texto constitucional; se este preconiza, no art. 170, a livre concorrência, então a neutralidade tributária exigirá que o resultado da norma tributária não seja redução do grau de concorrência no mercado. ${ }^{121}$

A neutralidade deve ser caracterizada como a intervenção estatal por meio da tributação, corrigindo as deficiências do mercado e visando a realizar os demais objetivos da ordem econômica. Dessa forma, a ideia de neutralidade fiscal passa a ser coerente com a realidade de indução e extrafiscalidade prevista na Constituição Federal, na medida em

117 BRAZUNA, José Luis Ribeiro. Defesa da Concorrência e Tributação - À Luz do artigo 146-A da Constituição. São Paulo: Quartier Latin, 2009, p. 142.

118 Ibid., loc. cit.

119 Ibid., p. 143.

120 ZILVETI, Fernando Aurelio. Variações sobre o princípio da neutralidade no direito tributário internacional. Direito Tributário Atual, São Paulo: Dialética, v. 19, 2005, p. 26.

121 SCHOUERI, Luis Eduardo. Livre concorrência e tributação. In: ROCHA, Valdir de Oliveira (Coord.). Grandes questões atuais do Direito Tributário. v. 11, São Paulo: Dialética, 2007, p. 255. 
que objetiva-se utilizá-la como instrumento de combate aos efeitos contrários à livre concorrência.

Instrumento fundamental da neutralidade tributária como instrumento concorrencial é a previsão do artigo 146-A da Constituição Federal de 1988, que permite a criação, por lei complementar, de critérios especiais de tributação, para prevenir desequilíbrios na concorrência.

O dispositivo constitucional permite que sejam provocados comportamentos dos agentes econômicos para corrigir as distorções dos mecanismos de mercado ou corrigir desvios de comportamento dos agentes que possam prejudicar a livre concorrência. ${ }^{122}$

Conclui-se, portanto, que, ainda que se reconheça que a tributação inevitavelmente tem repercussão econômica, regra geral, deve-se buscar por imposições tributárias que não se caracterizem como fator determinante nas decisões sobre a alocação de recursos, ou seja, que não alterem os preços relativos, minimizando sua interferência nas decisões econômicas dos agentes de mercado.

Excepcionalmente, em face de distorções do mercado, é possível relativizar o princípio da neutralidade fiscal para corrigir os referidos desvios, em prol da livre iniciativa e da livre concorrência, também garantidas constitucionalmente.

122 BRAZUNA, José Luis Ribeiro. Defesa da Concorrência e Tributação - À Luz do artigo 146-A da Constituição. São Paulo: Quartier Latin, 2009, p. 144. 


\section{IMPOSTO SOBRE A CIRCULAÇÃO DE MERCADORIAS E SERVIÇOS - ICMS}

\subsection{PeRFIL DO ICMS}

O artigo 155, II, da Constituição Federal estabelece que "compete aos Estados e ao Distrito Federal instituir impostos sobre operações relativas à circulação de mercadorias e sobre prestações de serviços de transporte interestadual e intermunicipal e de comunicação, ainda que as operações e as prestações se iniciem no exterior."

A Constituição Federal, portanto, atribuiu aos Estados e ao Distrito Federal a competência para instituir o Imposto sobre Operações de Circulação de Mercadorias e Serviços - ICMS. Excepcionalmente, a União Federal também tem competência para instituir o ICMS, na iminência ou no caso de guerra externa, por força do disposto nos $\operatorname{artigos} 147^{123}$ e 154, II $^{124}$ da Carta Magna.

Roque Antonio Carrazza afirma que a competência atribuída pela Constituição Federal aos Estados e Distrito Federal engloba, no mínimo, cinco impostos diferentes:

a) o imposto sobre operações mercantis (operações relativas à circulação de mercadorias), que, de algum modo, compreende o que nasce da entrada, na Unidade Federada, de mercadorias importadas do exterior; b) o imposto sobre serviços de transporte interestadual e intermunicipal; c) o imposto sobre serviços de comunicação; d) o imposto sobre produção, importação, circulação, distribuição ou consumo de lubrificantes e combustíveis líquidos e gasosos e de energia elétrica; e,

${ }^{123}$ Constituição Federal

Artigo 147 - Competem à União, em Território Federal, os impostos estaduais e, se o Território não for dividido em Municípios, cumulativamente, os impostos municipais; ao Distrito Federal cabem os impostos municipais.

124 Constituição Federal

Artigo 154 - A União poderá instituir:

$[\ldots]$

II - na iminência de guerra externa, impostos extraordinários, compreendidos ou não em sua competência tributária, os quais serão suprimidos, gradativamente, cessadas as causas de sua criação. 
e) o imposto sobre a extração, circulação, distribuição ou consumo de minerais. ${ }^{125}$

Destaque-se, ainda, que a Emenda Constitucional $\mathrm{n}^{\circ}$. 33/2001 estabeleceu competência para os Estados instituírem ICMS sobre a importação de mercadorias, por pessoa física ou jurídica, ainda que não contribuinte do imposto.

Além de dispor sobre a competência e as hipóteses de incidência do ICMS, o artigo 155 da Constituição Federal dispõe sobre as principais características do imposto, bem como sobre os princípios aplicáveis à sua incidência.

Ademais, estabelece que cabe à lei complementar determinar a forma de incidência do ICMS, definindo os contribuintes, dispondo sobre o regime de substituição tributária e o sistema de compensação de créditos para garantir a não cumulatividade, regulando a forma como os Estados e o Distrito Federal concederão ou revogarão isenções, incentivos e benefícios fiscais.

O cuidado do Legislador Constituinte em detalhar constitucionalmente a forma de incidência do ICMS e garantir que suas características principais sejam estabelecidas por lei complementar federal revela a importância do referido tributo e seu caráter nacional, bem como a preocupação em garantir a uniformidade da sua incidência no território nacional, não obstante a existência da legislação de diversos Estados e do Distrito Federal.

Entre as principais previsões constitucionais para o ICMS figura a determinação de que o imposto "será não-cumulativo, compensando-se o que for devido em cada operação relativa à circulação de mercadorias ou prestação de serviços com o montante cobrado nas anteriores pelo mesmo ou por outro Estado ou pelo Distrito Federal". ${ }^{126}$

125 CARRAZZA, Roque Antonio. ICMS. 15. ed., rev. e ampl. até a EC 67/2011, de acordo com a Lei Complementar 87/1996 com suas ulteriores modificações. São Paulo: Malheiros, 2011, p. 37.

126 Cf. artigo 155, parágrafo 2, I da Constituição Federal. 
O objetivo do presente trabalho é estudar a forma como estabelecida a não cumulatividade do ICMS e as limitações ao aproveitamento do crédito, abordando as distorções trazidas pela legislação e pela sua aplicação pelos Estados.

O foco do trabalho estará relacionado com as distorções referentes ao ICMS incidente nas operações de circulação de mercadorias. Assim, antes de adentrar na análise da não cumulatividade, é importante abordar questões básicas referentes às operações de circulação de mercadorias.

O imposto sobre operações mercantis (operações relativas à circulação de mercadorias) tem como critério material a realização de operação comercial que implique na circulação de mercadorias. Ou seja, o ICMS não tributa as mercadorias, mas as operações, negócios jurídicos que resultem em sua circulação.

Ao conceituar circulação, Alcides Jorge Costa afirma ser a série de operações que levam as mercadorias da fonte de produção até o consumo final, agregando-lhes valor em cada etapa deste percurso, sendo irrelevante a transferência ou de posse ou propriedade:

Pode, contudo, haver circulação sem transferência de posse ou de propriedade. Quando um comerciante em nome individual consome mercadorias que adquiriu para revenda, existe circulação, dentro do conceito que tentamos construir à luz da Constituição. Admitida a existência dos demais elementos do fato gerador, este consumo acarretará incidência do ICM. ${ }^{127}$

De fato, é a conjugação da interpretação do conceito de circulação com os demais conceitos do fato gerador que permitirá identificar as operações sujeitas ao ICMS.

Assim, é importante estabelecer a noção de mercadoria. Mercadoria é o bem móvel sujeito à mercancia, posto em comércio. O que confere caráter de mercadoria a um objeto é a sua destinação. Carrazza conclui: "Para que um bem móvel seja havido por mercadoria, é mister que ele tenha por finalidade a venda ou revenda. Em suma, a qualidade distintiva

${ }^{127}$ COSTA, Alcides Jorge. ICM na Constituição e na Lei Complementar. São Paulo: Resenha Tributária, 1979, p. 87. 
entre um bem móvel (gênero) e mercadoria (espécie) é extrínseca, consubstanciando-se no propósito de destinação de mercadoria". ${ }^{128}$

Portanto, embora o conceito de circulação envolva operações que impliquem transferência ou não de posse ou propriedade, a sua conjugação com o termo de mercadoria, pela Constituição Federal, permite que sejam tributadas pelo ICMS apenas as operações que impliquem circulação de mercadoria, ou seja, de bens sujeitos à operações mercantis e, que, por isso, só podem ser as circulações jurídicas que pressupõem a transferência da posse ou da propriedade da mercadoria de uma pessoa para outra.

Apenas as operações que impliquem circulação de mercadorias, com a mudança da titularidade da mercadoria, é que podem ser tributadas pelo ICMS. Qualquer pessoa (física ou jurídica) pode ser contribuinte do ICMS, desde que pratique operações mercantis, com habitualidade.

A definição do momento em que se considera ocorrido o fato gerador do ICMS é atribuída ao legislador ordinário dos Estados e do Distrito Federal. Carrazza ${ }^{129}$ destaca que pode ser escolhido qualquer momento que tenha relação com o aspecto material, por exemplo, momento de entrada ou saída da mercadoria no estabelecimento ou momento da extração da nota fiscal. No entanto, destaca que não se pode considerar ocorrido o fato imponível em momento anterior à ocorrência da operação mercantil.

No entanto, a Constituição Federal autoriza a instituição de tributação antecipada pelo ICMS, como artifício para supostamente coibir fraudes tributárias. Tal possibilidade, cuja aplicação tem aumentado significativamente nos últimos anos, não pode ser considerada constitucional, à luz do que estabelece a não cumulatividade, conforme será abordado adiante.

${ }^{128}$ CARRAZZA, Roque Antonio. ICMS. 15. ed., rev. e ampl. até a EC 67/2011, de acordo com a Lei Complementar 87/1996 com suas ulteriores modificações. São Paulo: Malheiros, 2011, p. 45.

129 Ibid., p. 48-49. 


\subsection{APliCaÇão do PrincíPIO da NÃo CUMUlatividade ho ICMS}

A Constituição Federal estabelece expressamente que o ICMS deve sujeitar-se à não cumulatividade, conforme se verifica no artigo 155, parágrafo 2 , I e II, do Texto Constitucional:
Art. 155. [...]
Parágrafo $2^{\circ}-\mathrm{O}$ imposto previsto no inciso II atenderá ao seguinte:
I - será não-cumulativo, compensando-se o que for devido em cada operação relativa à circulação de mercadorias ou prestação de serviços ou pelo Distrito Federal; com o montante cobrado nas anteriores pelo mesmo ou por outro Estado
II - a isenção ou não incidência, salvo determinação em contrário da legislação:
a) não implicará crédito para compensação com o montante devido nas operações ou operações ou prestações seguintes;
b) acarretará anulação do crédito relativo às operações anteriores.

A não cumulatividade é um dos aspectos essenciais do ICMS e, geralmente, é classificada como princípio. No entanto, é importante indagar se a não cumulatividade é, de fato, princípio ou se é uma regra ou técnica de tributação.

O conjunto de normas que forma o Direito é composto por princípios e regras. Assim, tanto os princípios quanto as regras são normas.

Ao tratar dos conceitos de princípios e regras, o referido autor destaca que há diversas distinções que variam de acordo com o critério distintivo empregado, do fundamento teórico utilizado e da finalidade para a qual é feita. ${ }^{130}$

130 ÁVILA, Humberto. A distinção entre princípios e regras e a redefinição do dever de proporcionalidade. Revista Diálogo Jurídico, Salvador, CAJ - Centro de Atualização Jurídica, v. I, n. 4, jul. 2001. Disponível em: <http://www.direitopublico.com.br/pdf_4/dialogo-juridico-04-julho-2001-humbertoavila.pdf > . Acesso em: 14 ago. 2012, p. 5. 
Ávila cita as definições de Esser (os princípios não contêm diretamente ordens como as regras, mas apenas fundamentos para justificação de uma ordem), Wollf-Bachof e Forsthoff (os princípios funcionam como fundamentos jurídicos para as decisões, mas não possuem a qualidade de normas de comportamento como as regras, por ausência de determinação) e Larenz (os princípios estabelecem fundamentos normativos para a interpretação e aplicação do Direito, do qual decorrem as normas de comportamento), concluindo que estas se assemelham por distinguir os princípios das regras, com base em dois critérios: (i) grau de abstração e generalidade da prescrição normativa e (ii) fundamento de validade. Com base nestes critérios, resumidamente poderia se afirmar que os princípios seriam dirigidos a um número indeterminado de pessoas e circunstâncias e seriam dedutíveis do Estado de Direito, enquanto as regras seriam menos gerais e mais concretas e dedutíveis de textos normativos. ${ }^{131}$ Nesse contexto, Humberto Ávila resume:

Essa foi a primeira etapa da redefinição das normas jurídicas, em virtude da qual se constatou que pertencem ao Direito, possuindo por isso validade, não apenas aquelas normas que possuem uma prescrição determinada (regras), mas também aquelas que estabelecem prescrições ligadas indiretamente a valores, fins, idéias, e topoi a serem institucionalmente determinadas (princípios). ${ }^{132}$

Posteriormente, Ávila destaca as lições de Canaris (os princípios precisam de concretização por intermédio de regras), Dworkin (método 'tudo ou nada' da aplicação das regras e 'dimensão de peso' dos princípios - os princípios não determinam vinculativamente a decisão, contendo apenas fundamentos que devem ser conjugados com fundamentos de outros princípios, sobrepondo-se, em caso de colisão, o princípio com peso relativo maior, sem o que outro perca sua validade) e Alexy ('deveres de otimização': ponderação entre os princípios colidentes, que possuem apenas uma dimensão de peso e não determinam as consequências normativas de forma direta como as regras), que

\footnotetext{
131 ÁVILA, Humberto. A distinção entre princípios e regras e a redefinição do dever de proporcionalidade. Revista Diálogo Jurídico, Salvador, CAJ - Centro de Atualização Jurídica, v. I, n. 4, jul. 2001. Disponível em: <http://www.direitopublico.com.br/pdf_4/dialogo-juridico-04-julho-2001-humbertoavila.pdf >. Acesso em: 14 ago. 2012, p. 5-6.

132 Ibid., p. 7.
} 
tentaram determinar critérios objetivos para melhor fundamentar a interpretação e a aplicação baseada neles. ${ }^{133}$

Humberto Ávila, contudo, critica as teses dos referidos doutrinadores, uma vez que há regras que também são mais ou menos vagas e ambíguas, cuja implementação não pode ser realizada de forma imediata. Ademais, existem variadas formas de relacionamento entre as regras, em função das quais a decisão é modificada. ${ }^{134}$

Nesse contexto, conclui que, na verdade, é às razões e aos fins aos quais os princípios fazem referência que deve ser atribuída uma dimensão de importância. Dessa forma, tem-se que o verdadeiro elemento distintivo entre princípios e regras é o grau de abstração da previsão normativa (grau de determinação do fim e da conduta), uma vez que ambos, em maior ou menor grau, precisam de condições reais para a sua incidência, definindo-se as normas da seguinte forma:

Os princípios como normas que estabelecem diretamente fins, para cuja concretização estabelecem com menor exatidão qual o comportamento devido (menor grau de determinação da ordem e maior generalidade dos destinatários), e por isso dependem mais intensamente da sua relação com outras normas e de atos institucionalmente legitimados da interpretação para a determinação da conduta devida.

As regras podem ser definidas como normas que estabelecem indiretamente fins, para cuja concretização estabelecem com maior exatidão qual o comportamento devido (maior grau de determinação de ordem e maior especificação dos destinatários) e, por isso dependem menos intensamente da sua relação com outras normas e de atos institucionalmente legitimados de interpretação para a determinação da conduta devida. ${ }^{135}$

Assim, considerando que a não cumulatividade do ICMS prevista na Constituição Federal não é uma norma abstrata e genérica, mas uma norma específica e, conforme será tratado adiante, de aplicação imediata e de consequências de pronto verificáveis, devemos

133 ÁVILA, Humberto. A distinção entre princípios e regras e a redefinição do dever de proporcionalidade. Revista Diálogo Jurídico, Salvador, CAJ - Centro de Atualização Jurídica, v. I, n. 4, jul. 2001. Disponível em: <http://www.direitopublico.com.br/pdf_4/dialogo-juridico-04-julho-2001-humbertoavila.pdf >. Acesso em: 14 ago. 2012, p. 7-9.

134 Ibid., p. 13-14.

135 Ibid., p. 21. 
concluir que não se trata de um princípio, mas de uma regra que determina a técnica de tributação a ser adotada para instituição do imposto.

Pedro Guilherme Accorsi Lunardelli conclui que "a regra técnica da NãoCumulatividade não é um princípio, no sentido de um valor, um fim reconhecido como válido no sistema jurídico". 136

Luiz Rogério Sawaya Batista, ao analisar a questão, também afirma que a não cumulatividade tem natureza jurídica de regra/técnica de tributação:

Desse modo, entendemos que a não-cumulatividade do ICMS não encerra um valor e sequer pode ser qualificada como estruturante do sistema jurídico, não admitindo gradação, e estando, a sua aplicação, restrita e sujeita ao fato de o ICMS ser devido na operação relativa à circulação de mercadorias e prestação de serviços, conforme disposto no inciso I, do parágrafo $2^{\circ}$, do artigo 155 , da Constituição Federal. Trata-se, pois, de uma genuína regra. ${ }^{137}$

De qualquer forma, ainda que se trate de técnica/regra de tributação e não de princípio, por ter sido consagrada constitucionalmente, a não cumulatividade não pode ser desconsiderada pelo legislador infraconstitucional, devendo ser rigorosamente observada. Em virtude da previsão na Constituição Federal, sem nenhuma restrição, exceto aquelas impostas pela própria Carta Magna, a não cumulatividade confere direito de crédito amplo ao contribuinte do ICMS, de aplicação objetiva. ${ }^{138}$ Nesse sentido, Carrazza afirma:

A regra em exame não encerra mera sugestão, que o legislador ou a Fazenda Pública poderão seguir ou deixar de seguir. Muito pelo contrário, ela aponta uma diretriz imperativa, que dá ao contribuinte o direito subjetivo de ver observado, em caso concreto, o princípio da nãocumulatividade. ${ }^{139}$

${ }^{136}$ LUNARDELLI, Pedro Guilherme Accorsi. A Não-Cumulatividade do ICMS - uma aplicação da teoria sobre as regras do Direito e as regras dos jogos. São Paulo: Quartier Latin, 2009, p. 178.

137 BATISTA, Luiz Rogério Sawaya. Créditos do ICMS na Guerra Fiscal. São Paulo: Quartier Latin, 2012, p. 50 .

138 Ibid., loc. cit.

139 CARRAZZA, Roque Antonio. ICMS. 15. ed., rev. e ampl. até a EC 67/2011, de acordo com a Lei Complementar 87/1996 com suas ulteriores modificações. São Paulo: Malheiros, 2011, p. 382. 
O objetivo do Constituinte ao garantir a observância da não cumulatividade na instituição do ICMS é assegurar a neutralidade na concorrência, tributando apenas a manifestação de capacidade contributiva do consumidor final e minimizando os efeitos nocivos da tributação sobre o consumo pelo ICMS no processo de produção. ${ }^{140}$

Sobre o assunto, Bonilha pontua:

No entanto, e sem embargo da rentabilidade e das qualidades positivas, os impostos de vendas passaram a ser objeto de restrições e estudos, a fim de que se encontrassem soluções econômicas e jurídicas que minimizassem os seus efeitos nocivos sobre a produção. Entendeu-se que o ideal seria neutralizá-lo, economicamente, tornando-o independente das relações existentes entre a empresa e o processo de produção. ${ }^{141}$

Assim, a não cumulatividade objetiva atingir tão-somente o valor pago pelo consumidor final e não a despesa do produtor:

\begin{abstract}
A não cumulatividade, então, tem como objetivo proteger os impostos incidentes sobre operações de circulação de mercadorias e serviços para que componham o custo dos mesmos, evitando a cumulação, ou seja, a tributação em cascata. Através dela, o Estado garante a arrecadação tributária advinda da incidência dos impostos em todas as etapas do processo produtivo, mas o verdadeiro ônus do imposto será assumido pelo consumidor final. ${ }^{142}$
\end{abstract}

Passaremos, então, a tratar dos mecanismos de dedução previstos na Carta Magna, que visam garantir a não cumulatividade.

\title{
3.2.1 MECANiSMos de DedUÇão
}

O parágrafo $2^{\circ}$ do artigo 155 da Constituição Federal dispõe que a não cumulatividade do ICMS é obtida "compensando-se o que for devido em cada operação

\footnotetext{
140 TEIXEIRA, Alessandra Machado Brandão. A Tributação sobre o Consumo de Bens e Serviços. Belo Horizonte: Mandamentos, 2002, p. 184-185.

141 BONILHA, Paulo Celso Bergstrom. Alguns aspectos do imposto de circulação de mercadorias. In: NOGUEIRA, Ruy Barbosa (Coord.). Direito Tributário - Estudos de problemas e casos tributários. São Paulo: José Bushatsky, 1973, p. 296.

142 TEIXEIRA, op. cit., p. 194.
} 
relativa à circulação de mercadorias ou prestação de serviços com o montante cobrado nas anteriores [...]"'.

Ou seja, em cada operação, o contribuinte tem assegurado o direito a um abatimento equivalente aos montantes cobrados nas operações ou prestações anteriores. Subtraindo-se do valor devido o valor do tributo cobrado nas operações anteriores, o contribuinte irá recolher apenas a diferença resultante da subtração. ${ }^{143}$

Portanto, a compensação prevista na Constituição Federal se operacionaliza por meio de um sistema de crédito/débito, em que o contribuinte efetua o recolhimento apenas da diferença entre seus créditos e débitos. Carrazza afirma que "de fato, a compensação a que estamos a aludir efetiva-se por intermédio da chamada 'conta corrente fiscal', em que o saldo, se devedor, é pago pelo contribuinte e, se credor, é transferido para aproveitamento em períodos subsequentes". ${ }^{144}$

Nessa sistemática, a entrada tributada em um estabelecimento equivale ao direito de crédito do contribuinte. Por sua vez, na operação de saída, há um débito do contribuinte. Periodicamente, conforme fixado pela lei, é realizado o encontro de créditos e débitos. Se houver mais créditos, o contribuinte terá um saldo credor para aproveitar nos próximos períodos. Se, ao contrário, houver mais débitos, o contribuinte terá que recolher a diferença. ${ }^{145}$ Para exemplificar, Christine Mendonça utiliza o seguinte esquema ${ }^{146}$ :

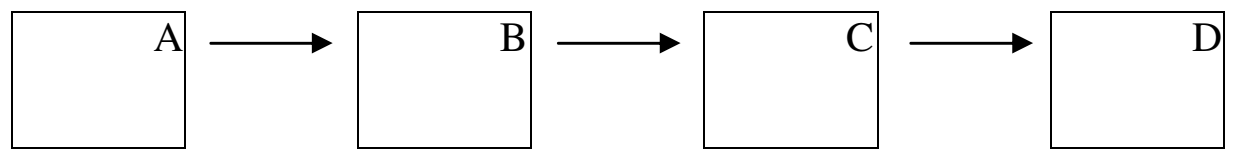

\begin{tabular}{|c|c|c|}
\hline $\mathrm{A} \longrightarrow \mathrm{B}$ & $\mathrm{B} \longrightarrow \mathrm{C}$ & $\mathrm{C} \longrightarrow \mathrm{D}$ \\
\hline Valor da Operação (bc): $\mathrm{R} \$ 100,00$ & Valor da Operação (bc): $\mathrm{R} \$ 140,00$ & Valor da Operação (bc): $\mathrm{R} \$ 196,00$ \\
\hline Crédito Tributário: $\mathrm{R} \$ 18,00$ & Crédito Tributário: $\mathrm{R} \$ 25,20$ & Crédito Tributário: $\mathrm{R} \$ 35,28$ \\
\hline Débito do fisco & Débito do fisco: $\mathrm{R} \$ 18,00$ & Débito do fisco: $\mathrm{R} \$ 25,20$ \\
\hline Valor recolhido (CT-DF): $\mathrm{R} \$ 18,00$ & Valor recolhido (CT-DF): $\mathrm{R} \$ 7,20$ & Valor recolhido (CT-DF): $\mathrm{R} \$ 10,08$ \\
\hline
\end{tabular}

143 CARRAZZA, Roque Antonio. ICMS. 15. ed., rev. e ampl. até a EC 67/2011, de acordo com a Lei Complementar 87/1996 com suas ulteriores modificações. São Paulo: Malheiros, 2011, p. 384.

144 Ibid., p. 414.

145 MENDONÇA, Christine. A Não-Cumulatividade do ICMS. São Paulo: Quartier Latin, 2005, p. 94.

146 Ibid., loc. cit. 
Alcides Jorge Costa também explica o método de forma didática:

Portanto, o cálculo do ICM a recolher é feito por períodos e resulta das seguintes operações:

(a) soma dos resultados da aplicação à base de cálculo de cada operação realizada no período;

(b) soma do ICM relativamente às mercadorias entradas no estabelecimento no mesmo período;

(c) diferença entre (a) e (b).

O ICM a recolher é igual à diferença desfavorável ao contribuinte no período. Se a diferença lhe for favorável, transfere-se para o período seguinte. ${ }^{147}$

É importante notar que o ICMS não se caracteriza como imposto sobre valor agregado. Isso porque, conforme mencionado acima, não incide sobre a parcela acrescida na operação, tributando o valor adicionado ao bem. ${ }^{148} \mathrm{O}$ ICMS incide sobre o valor total da operação e não o valor da diferença entre as operações de compra e venda. ${ }^{149}$

\subsubsection{CRÉditos Físicos E CRÉditos FinanCEIRos}

A não cumulatividade pode ser obtida através de dois sistemas: adoção do sistema de créditos físicos ou de créditos financeiros.

Pela sistemática do crédito físico, o aproveitamento do crédito está condicionado à aplicação física das mercadorias que ingressam no estabelecimento no produto tributado ou revendido. Ou seja, as mercadorias ingressadas devem obrigatoriamente ser agregadas na mercadoria que sairá do estabelecimento.

${ }^{147}$ COSTA, Alcides Jorge. ICM na Constituição e na Lei Complementar. São Paulo: Resenha Tributária, 1979, p. 151.

148 CARRAZZA, Roque Antonio. ICMS. 15. ed., rev. e ampl. até a EC 67/2011, de acordo com a Lei Complementar 87/1996 com suas ulteriores modificações. São Paulo: Malheiros, 2011, p. 407.

149 MENDONÇA, Christine. A Não-Cumulatividade do ICMS. São Paulo: Quartier Latin, 2005, p. 95. 
É, portanto, um sistema restritivo de créditos, no qual não se permite a tomada de créditos referentes ao imposto pago nas operações anteriores referentes à aquisição de máquinas, ferramentas e bens do ativo fixo, por exemplo. É apenas permitido o crédito dos bens adquiridos que se incorporam fisicamente ao produto final ou que são consumidos no curso do processo de produção. Schoueri conclui:

Assim, em uma primeira aproximação, denominada crédito físico, apenas se pode cogitar crédito de tributo pago em etapa anterior se esta compreendeu um produto agregado, fisicamente, àquele tributado na etapa seguinte. Ou seja: A matéria-prima, porque componente físico do produto final, considera-se incorporada àquele, assegurando-se, na venda do último, que se compense o tributo que incidiu na transação de aquisição da primeira. Ainda na ideia de crédito físico, admite-se que um ou outro produto não se integre ao produto revendido, mas tenha sido desgastado na sua produção, autorizando-se, assim, o creditamento do tributo incidentes sobre aquele. ${ }^{150}$

Resumidamente, o crédito financeiro se relaciona exclusivamente com os produtos que integram o produto final. ${ }^{151}$

No caso do sistema de crédito financeiro, o direito ao crédito do imposto pago nas operações anteriores é amplo e irrestrito, já que se permite o aproveitamento de crédito das operações de entrada de bens no estabelecimento que não se incorporam direta ou fisicamente no bem produzido. $\mathrm{O}$ direito ao crédito abrange o imposto relativo a qualquer bem adquirido pelo estabelecimento, essencial e imprescindível à atividade.

Permite-se, assim, a dedução do imposto relativo à entrada de bens no ativo imobilizado, material de embalagem e bens instrumentais. ${ }^{152}$

Sobre a definição dos dois sistemas, Ricardo Lobo Torres resume:

Os impostos não-cumulativos podem adotar o sistema de crédito físico, em que se deduzem do imposto a pagar as quantias correspondentes aos tributos que anteriormente incidiram sobre as mercadorias empregadas

\footnotetext{
150 SCHOUERI, Luis Eduardo. Direito Tributário. São Paulo: Saraiva, 2011, p. 367.

151 TEIXEIRA, Alessandra Machado Brandão. A Tributação sobre o Consumo de Bens e Serviços. Belo Horizonte: Mandamentos, 2002, p. 88.

152 Ibid., loc. cit.
} 
fisicamente na industrialização ou comercialização; ou o do crédito financeiro, em que se deduzem todas as despesas necessárias à produção do bem. ${ }^{153}$

Colocadas essas premissas, passamos a analisar o Texto Constitucional, a fim de identificar o sistema adotado para o ICMS.

$\mathrm{O}$ inciso I, do parágrafo $2^{\circ}$, do artigo 155 da Constituição Federal utiliza a expressão "compensando-se o quer for devido em cada operação relativa à circulação de mercadorias ou prestação de serviços com o montante cobrado nas anteriores pelo mesmo ou outro Estado ou pelo Distrito Federal”.

Referindo-se a "cada operação" e não cada mercadoria ou bem, o Texto Constitucional deixa expresso que a compensação prevista para o ICMS não se limita aos créditos físicos. A Constituição Federal não se refere a "cada mercadoria", de modo que é irrelevante a origem ou destinação dos créditos de ICMS.

Assim, Carrazza conclui que a Carta Magna não exige que os créditos provenham da mesma mercadoria, bem ou serviços. ${ }^{154} \mathrm{O}$ crédito provém de operações ou prestações anteriores, ainda que os bens ou serviços não se integrem fisicamente na operação subsequente.

Reconhece o autor que a Constituição Federal confere ao contribuinte o aproveitamento de crédito de ICMS pago em operações anteriores referente a todas as mercadorias e bens tributados, sem limites (máquinas, material de escritórios, veículos etc.). ${ }^{155}$

Ou seja, independentemente da origem ou destinação que será dada às mercadorias ou bens adquiridos (revenda, uso, consumo etc.), o contribuinte terá direito integral ao

153 TORRES, Ricardo Lobo. O princípio da não-cumulatividade e o IVA no Direito Comparado. In: MARTINS, Ives Gandra da Silva (Coord.). O Princípio da não-cumulatividade. São Paulo: Revista dos Tribunais; Centro de Extensão Universitária, 2004, p. 147.

154 CARRAZZA, Roque Antonio. ICMS. 15. ed., rev. e ampl. até a EC 67/2011, de acordo com a Lei Complementar 87/1996 com suas ulteriores modificações. São Paulo: Malheiros, 2011, p. 405.

155 Ibid., p. 406-407. 
crédito, exceto nos casos em que a própria Constituição Federal estabeleça algum tipo limite.

Embora tratando de Constituição Federal anterior, mas analisando as expressões operações e montante cobrado nas operações anteriores também adotadas pela Constituição em vigência, Alcides Jorge Costa conclui:

Cada operação diz respeito a mercadoria determinada. Se a mercadoria não é objeto de operações posteriores (como v.g., o equipamento de uma fábrica) não haveria como abater o imposto incidentes nas operações anteriores relativas a esta mercadoria. Caso exato o argumento, o ICMS seria um imposto tipo produto bruto, e bastante estrito: só poderia ser abatido o imposto incidente sobre operações concernente à mesma mercadoria, ou a mercadorias que tivessem entrado na composição da mercadoria vendida.

Este argumento não procede. A Constituição menciona 'operações' e abatimento do 'montante cobrado nas operações anteriores', sem especificar que as operações consideradas devem dizer respeito à mesma mercadoria. ${ }^{156}$

Conclui-se, dessa forma, que a técnica da não cumulatividade prevista na Constituição Federal, garante ao contribuinte a compensação do ICMS incidente em operações anteriores, independentemente da origem e do destino da mercadoria.

Tal premissa será importante quando for abordado o alcance da lei complementar no que se refere à não cumulatividade.

\subsubsection{O Direito de Crédito e a Efetiva Cobrança nas Operações ANTERIORES}

Outro aspecto que se discute sobre a técnica da não cumulatividade prevista na Constituição Federal diz respeito à adoção da expressão cobrados.

156 COSTA, Alcides Jorge. ICM na Constituição e na Lei Complementar. São Paulo: Resenha Tributária, 1979, p. 149-150. 
Afirma-se que essa redação limitaria o direito de créditos aos montantes efetivamente cobrados em operações anteriores.

Tal interpretação é descabida, pois não é possível exigir do contribuinte que se saiba se o Estado cobrou ou não imposto na operação anterior e, ainda, se de fato houve recolhimento.

Dessa forma, Alcides Jorge Costa conclui que o termo cobrado não deve ser entendido como concretamente exigido, mas, sim, no sentido de "incidir". 157

Christine Mendonça explica que não se pode confundir "cobrado", que significa exigido e pressupõe uma atividade do sujeito ativo, um pagamento, ou seja, recolhimento efetivo de valores que pressupõe um ato do sujeito passivo. Mesmo porque, conforme destacado acima, há uma impossibilidade de caráter operacional, na medida em que é impossível que o contribuinte comprove o recolhimento do ICMS em todas as operações anteriores praticadas por terceiros. ${ }^{158}$

Paulo Bergstrom Bonilha conclui:

A expressão 'cobrado', senhores, a meu ver (e a doutrina, em geral, tem uma posição um pouco diversa desta) significa 'cobrável', quer dizer, que foi objeto de lançamento regular. Não significa, necessariamente, imposto que o contribuinte já desembolsou: que efetivamente entregou ao Poder Público. [...] Então, 'imposto cobrado' é o imposto que pode ser, ou foi, objeto de um lançamento, necessariamente. ${ }^{159}$

É suficiente, portanto, que o ICMS tenha incidido sobre as operações anteriores para que nasça o direito de crédito na operação subsequente, permanecendo íntegro esse direito, mesmo que um dos contribuintes deixe de efetuar o pagamento do tributo. ${ }^{160}$

${ }^{157}$ COSTA, Alcides Jorge. ICM na Constituição e na Lei Complementar. São Paulo: Resenha Tributária, 1979, p. 156.

158 MENDONÇA, Christine. A Não-Cumulatividade do ICMS. São Paulo: Quartier Latin, 2005, p. 119-120.

159 Apud MENDONÇA, Christine. A Não-Cumulatividade do ICMS. São Paulo: Quartier Latin, 2005, p. 120.

${ }^{160}$ CARRAZZA, Roque Antonio. ICMS. 15. ed., rev. e ampl. até a EC 67/2011, de acordo com a Lei Complementar 87/1996 com suas ulteriores modificações. São Paulo: Malheiros, 2011, p. 405. 
Assim, o direito de crédito do ICMS independe do fato de haver a efetiva cobrança do imposto nas operações ou prestações anteriores.

\subsubsection{Regime de SUbSTITUIÇÃo Tributária}

Os artigos 121, II, e 128 do Código Tributário Nacional autorizam a atribuição de modo expresso a terceira pessoa, vinculada ao fato gerador da respectiva obrigação, por lei, como sujeito passivo/responsável pelo crédito tributário, excluindo a responsabilidade do contribuinte ou atribuindo-a a este em caráter supletivo do cumprimento total ou parcial da referida obrigação.

Obedecidos os requisitos do artigo 128 do Código Tributário Nacional, quais sejam, previsão em lei e vinculação do responsável ao fato gerador do tributo, passaremos a analisar o regime de substituição tributária do ICMS.

$\mathrm{Na}$ substituição tributária, o substituto que, embora não tenha realizado o fato imponível, deve, de alguma forma, estar a ele vinculado, é, por lei, indicado como sujeito passivo da obrigação tributária, respondendo pelo cumprimento da obrigação principal e dos correlatos deveres instrumentais.

De acordo com Paulo Antonio Mariano, Raphael Werneck e Sandra Regina Alencar Bezerra, há três formas de substituição tributária para o ICMS, na Lei Complementar 87/96: (i) substituição tributária antecedente ou "para trás", (ii) substituição tributária concomitante e (iii) substituição tributária "para frente". ${ }^{161}$

Na substituição tributária "para trás", os fatos geradores ocorrem antes do momento do recolhimento do tributo, ou seja, o tributo será recolhido na operação subsequente, pelo substituto em nome do substituído ${ }^{162}$ :

161 MARIANO, Antonio Paulo; WERNECK, Raphael; BEZERRA, Sandra Regina Alencar. Substituição Tributária no ICMS: aspectos jurídicos e práticos. São Paulo: IOB, 2009, p. 57-58.

162 Ibid., p. 57. 
No plano vertical da sucessão de operações, no entanto, cujo vetor de direção é o percurso da produção até o consumo (circulação), há substituição tributária para trás (regressiva) nas hipóteses em que a lei determina que o imposto devido pela ocorrência do fato gerador em determinada etapa será pago por ocasião de uma específica operação em etapa subsequente, a cargo do contribuinte desta fase de circulação. ${ }^{163}$

Carrazza destaca que a carga econômica do tributo não é suportada pelo substituído, mas pelo substituto. ${ }^{164}$

Na substituição tributária concomitante, o recolhimento do tributo ocorre no mesmo instante em que se considera ocorrido o fato gerador. ${ }^{165}$

Na substituição tributária "para frente", o recolhimento do tributo ocorre em momento anterior à ocorrência do fato imponível. O fato gerador é subsequente, ocorrerá em momento futuro, e a cobrança do imposto é feita antecipadamente e seu cumprimento atribuído ao substituto:

Na substituição para frente ou progressiva, por sua vez, o contribuinte de determinada operação deverá recolher não só o tributo porventura incidente sobre a saída da sua mercadoria, como também antecipar o imposto devido sobre as prováveis operações subsequentes, adotando por base de cálculo um valor presumível, calculado em função das supostas características quantitativas do derradeiro (e futuro) fato gerador. ${ }^{166}$

A instituição dos regimes de substituição tributária no caso do ICMS é justificada pelo interesse dos Estados e Distrito Federal em estabelecer um controle de arrecadação mais efetivo e prático, diminuindo a evasão fiscal, já que os recolhimentos geralmente são concentrados nas fases da cadeia produtiva, que facilitam a fiscalização.

Ocorre que, antes uma exceção à regra, o regime de substituição tributária, especialmente de substituição tributária "para frente", tem sido empregado com uma

163 BONILHA, Paulo Celso Bergstron. Notas sobre as deformações da incidência plurifásica do ICMS. Direito Tributário Atual, São Paulo: Dialética, n. 23, 2009, p. 405.

164 CARRAZZA, Roque Antonio. ICMS. 15. ed., rev. e ampl. até a EC 67/2011, de acordo com a Lei Complementar 87/1996 com suas ulteriores modificações. São Paulo: Malheiros, 2011, p. 354.

165 MARIANO; WERNECK; BEZERRA, op. cit., p. 58.

166 BONILHA, op. cit., loc. cit. 
frequência cada vez maior, abrangendo um número crescente de mercadorias. Nesse sentido, o Prof. Paulo Celso Bergstrom Bonilha pontua:

Muitas vezes, por razões de inexistência de contabilidade regular, de risco ou de comodidade para a arrecadação, outras por interesse de contribuintes, a lei reduz as fases de circulação em que se desdobraria, normalmente, a incidência plurifásica de determinados produtos, em geral na fase inicial do fluxo de operações que compõem a circulação de bens.

$[\ldots]$

Todavia, no Brasil, o cenário atual é de franca deformação da estrutura da incidência multifásica do ICMS, não só em decorrência das reduções citadas, como também pelo uso abusivo de expedientes calcados na substituição tributária. ${ }^{167}$

Dessa forma, é importante analisar a constitucionalidade desse regime.

As substituições tributárias "para trás" e a concomitante, a princípio, não possuem nenhuma inconstitucionalidade ou ilegalidade. Conforme esclarecido acima, devem apenas ser observados os requisitos do artigo 128 do Código Tributário Nacional para sua instituição.

Ademais, no caso do ICMS, o artigo 155, parágrafo $2^{\circ}$, XII, "b" estabelece que lei complementar federal irá dispor sobre o regime de substituição tributária, o que foi feito nos artigos 6 a 12 da Lei Complementar $n^{\circ} 87 / 96 .{ }^{168}$

${ }^{167}$ BONILHA, Paulo Celso Bergstron. Notas sobre as deformações da incidência plurifásica do ICMS. Direito Tributário Atual, São Paulo: Dialética, n. 23, 2009, p. 403-404.

168 Art. $6^{\circ}$ Lei estadual poderá atribuir a contribuinte do imposto ou a depositário a qualquer título a responsabilidade pelo seu pagamento, hipótese em que assumirá a condição de substituto tributário. $\S 1^{\circ}$ A responsabilidade poderá ser atribuída em relação ao imposto incidente sobre uma ou mais operações ou prestações, sejam antecedentes, concomitantes ou subseqüentes, inclusive ao valor decorrente da diferença entre alíquotas interna e interestadual nas operações e prestações que destinem bens e serviços a consumidor final localizado em outro Estado, que seja contribuinte do imposto.

$\S 2^{\circ}$ A atribuição de responsabilidade dar-se-á em relação a mercadorias, bens ou serviços previstos em lei de cada Estado.

Art. $7^{\circ}$ Para efeito de exigência do imposto por substituição tributária, inclui-se, também, como fato gerador do imposto, a entrada de mercadoria ou bem no estabelecimento do adquirente ou em outro por ele indicado.

Art. $8^{\circ}$ A base de cálculo, para fins de substituição tributária, será:

I - em relação às operações ou prestações antecedentes ou concomitantes, o valor da operação ou prestação 
II - em relação às operações ou prestações subseqüentes, obtida pelo somatório das parcelas seguintes: a) o valor da operação ou prestação própria realizada pelo substituto tributário ou pelo substituído b) o montante dos valores de seguro, de frete e de outros encargos cobrados ou transferíveis aos adquirentes ou tomadores de serviço;

c) a margem de valor agregado, inclusive lucro, relativa às operações ou prestações subseqüentes.

$\S 1^{\circ} \mathrm{Na}$ hipótese de responsabilidade tributária em relação às operações ou prestações antecedentes, o imposto devido pelas referidas operações ou prestações será pago pelo responsável, quando:

I - da entrada ou recebimento da mercadoria, do bem ou do serviço;

II - da saída subseqüente por ele promovida, ainda que isenta ou não tributada;

III - ocorrer qualquer saída ou evento que impossibilite a ocorrência do fato determinante do pagamento do imposto.

$\S 2^{\circ}$ Tratando-se de mercadoria ou serviço cujo preço final a consumidor, único ou máximo, seja fixado por órgão público competente, a base de cálculo do imposto, para fins de substituição tributária, é o referido preço por ele estabelecido.

$\S 3^{\circ}$ Existindo preço final a consumidor sugerido pelo fabricante ou importador, poderá a lei estabelecer como base de cálculo este preço.

$\S 4^{\circ}$ A margem a que se refere a alínea c do inciso II do caput será estabelecida com base em preços usualmente praticados no mercado considerado, obtidos por levantamento, ainda que por amostragem ou através de informações e outros elementos fornecidos por entidades representativas dos respectivos setores, adotando-se a média ponderada dos preços coletados, devendo os critérios para sua fixação ser previstos em lei.

$\S 5^{\circ} \mathrm{O}$ imposto a ser pago por substituição tributária, na hipótese do inciso II do caput, corresponderá à diferença entre o valor resultante da aplicação da alíquota prevista para as operações ou prestações internas do Estado de destino sobre a respectiva base de cálculo e o valor do imposto devido pela operação ou prestação própria do substituto.

$\S 6^{\circ}$ Em substituição ao disposto no inciso II do caput, a base de cálculo em relação às operações ou prestações subseqüentes poderá ser o preço a consumidor final usualmente praticado no mercado considerado, relativamente ao serviço, à mercadoria ou sua similar, em condições de livre concorrência, adotando-se para sua apuração as regras estabelecidas no $\S 4^{\circ}$ deste artigo.

Art. $9^{\circ}$ A adoção do regime de substituição tributária em operações interestaduais dependerá de acordo específico celebrado pelos Estados interessados.

$\S 1^{\circ}$ A responsabilidade a que se refere o art. $6^{\circ}$ poderá ser atribuída:

I - ao contribuinte que realizar operação interestadual com petróleo, inclusive lubrificantes, combustíveis líquidos e gasosos dele derivados, em relação às operações subseqüentes;

II - às empresas geradoras ou distribuidoras de energia elétrica, nas operações internas e interestaduais, na condição de contribuinte ou de substituto tributário, pelo pagamento do imposto, desde a produção ou importação até a última operação, sendo seu cálculo efetuado sobre o preço praticado na operação final, assegurado seu recolhimento ao Estado onde deva ocorrer essa operação.

$\S 2^{\circ}$ Nas operações interestaduais com as mercadorias de que tratam os incisos I e II do parágrafo anterior, que tenham como destinatário consumidor final, o imposto incidente na operação será devido ao Estado onde estiver localizado o adquirente e será pago pelo remetente.

Art. 10. É assegurado ao contribuinte substituído o direito à restituição do valor do imposto pago por força da substituição tributária, correspondente ao fato gerador presumido que não se realizar.

$\S 1^{\circ}$ Formulado o pedido de restituição e não havendo deliberação no prazo de noventa dias, o contribuinte substituído poderá se creditar, em sua escrita fiscal, do valor objeto do pedido, devidamente atualizado segundo os mesmos critérios aplicáveis ao tributo.

$\S 2^{\circ} \mathrm{Na}$ hipótese do parágrafo anterior, sobrevindo decisão contrária irrecorrível, o contribuinte substituído, no prazo de quinze dias da respectiva notificação, procederá ao estorno dos créditos lançados, também devidamente atualizados, com o pagamento dos acréscimos legais cabíveis.

Art. 11. O local da operação ou da prestação, para os efeitos da cobrança do imposto e definição do estabelecimento responsável, é:

I - tratando-se de mercadoria ou bem:

a) o do estabelecimento onde se encontre, no momento da ocorrência do fato gerador;

b) onde se encontre, quando em situação irregular pela falta de documentação fiscal ou quando acompanhado de documentação inidônea, como dispuser a legislação tributária; 
c) o do estabelecimento que transfira a propriedade, ou o título que a represente, de mercadoria por ele adquirida no País e que por ele não tenha transitado;

d) importado do exterior, o do estabelecimento onde ocorrer a entrada física;

e) importado do exterior, o do domicílio do adquirente, quando não estabelecido;

f) aquele onde seja realizada a licitação, no caso de arrematação de mercadoria ou bem importados do exterior e apreendidos ou abandonados;

g) o do Estado onde estiver localizado o adquirente, inclusive consumidor final, nas operações interestaduais com energia elétrica e petróleo, lubrificantes e combustíveis dele derivados, quando não destinados à industrialização ou à comercialização;

h) o do Estado de onde o ouro tenha sido extraído, quando não considerado como ativo financeiro ou

i) o de desembarque do produto, na hipótese de captura de peixes, crustáceos e moluscos;

II - tratando-se de prestação de serviço de transporte:

a) onde tenha início a prestação;

b) onde se encontre o transportador, quando em situação irregular pela falta de documentação fiscal ou quando acompanhada de documentação inidônea, como dispuser a legislação tributária;

c) o do estabelecimento destinatário do serviço, na hipótese do inciso XIII do art. 12 e para os efeitos do $\S$ $3^{\circ}$ do art. 13;

III - tratando-se de prestação onerosa de serviço de comunicação:

a) o da prestação do serviço de radiodifusão sonora e de som e imagem, assim entendido o da geração, emissão, transmissão e retransmissão, repetição, ampliação e recepção;

b) o do estabelecimento da concessionária ou da permissionária que forneça ficha, cartão, ou assemelhados com que o serviço é pago;

c) o do estabelecimento destinatário do serviço, na hipótese e para os efeitos do inciso XIII do art. 12;

c-1) o do estabelecimento ou domicílio do tomador do serviço, quando prestado por meio de satélite;

d) onde seja cobrado o serviço, nos demais casos;

IV - tratando-se de serviços prestados ou iniciados no exterior, o do estabelecimento ou do domicílio do destinatário.

$\S 1^{\circ} \mathrm{O}$ disposto na alínea $\mathrm{c}$ do inciso I não se aplica às mercadorias recebidas em regime de depósito de contribuinte de Estado que não o do depositário.

$\S 2^{\circ}$ Para os efeitos da alínea h do inciso I, o ouro, quando definido como ativo financeiro ou instrumento cambial, deve ter sua origem identificada.

$\S 3^{\circ}$ Para efeito desta Lei Complementar, estabelecimento é o local, privado ou público, edificado ou não, próprio ou de terceiro, onde pessoas físicas ou jurídicas exerçam suas atividades em caráter temporário ou permanente, bem como onde se encontrem armazenadas mercadorias, observado, ainda, o seguinte:

I - na impossibilidade de determinação do estabelecimento, considera-se como tal o local em que tenha sido efetuada a operação ou prestação, encontrada a mercadoria ou constatada a prestação;

II - é autônomo cada estabelecimento do mesmo titular;

III - considera-se também estabelecimento autônomo o veículo usado no comércio ambulante e na captura de pescado;

IV - respondem pelo crédito tributário todos os estabelecimentos do mesmo titular.

$\S 4^{\circ}$ (VETADO)

$\S 5^{\circ}$ Quando a mercadoria for remetida para armazém geral ou para depósito fechado do próprio contribuinte, no mesmo Estado, a posterior saída considerar-se-á ocorrida no estabelecimento do depositante, salvo se para retornar ao estabelecimento remetente.

$\S 6^{\circ} \mathrm{Na}$ hipótese do inciso III do caput deste artigo, tratando-se de serviços não medidos, que envolvam localidades situadas em diferentes unidades da Federação e cujo preço seja cobrado por períodos definidos, o imposto devido será recolhido em partes iguais para as unidades da Federação onde estiverem localizados o prestador e o tomador.

Art. 12. Considera-se ocorrido o fato gerador do imposto no momento:

I - da saída de mercadoria de estabelecimento de contribuinte, ainda que para outro estabelecimento do mesmo titular;

II - do fornecimento de alimentação, bebidas e outras mercadorias por qualquer estabelecimento;

III - da transmissão a terceiro de mercadoria depositada em armazém geral ou em depósito fechado, no Estado do transmitente; 
Assim, os legisladores estaduais devem respeitar os limites impostos pela referida lei complementar, não podendo inovar nos pontos já regulamentados. Para instituir o regime de substituição tributária, para operações internas, os Estados e Distrito Federal devem editar uma lei, respeitando as diretrizes da Lei Complementar $n^{\circ}$ 87/96.

No caso de operações interestaduais, a instituição do regime de substituição tributária depende ainda da celebração de convênio ou protocolo pelos Estados e Distrito Federal, conforme artigos 150 , parágrafo $6^{\circ}$, combinado com artigo 155 , parágrafo $2^{\circ}$, XII, "g" da Constituição Federal e artigo $1^{\circ}$ da Lei Complementar $n^{\circ} 24 / 75 .{ }^{169}$ A exigência de celebração de acordo entre os Estados se justifica pelo fato de que o tributo será fracionado entre o Estado de origem e o Estado de destino da mercadoria. ${ }^{170}$

IV - da transmissão de propriedade de mercadoria, ou de título que a represente, quando a mercadoria não tiver transitado pelo estabelecimento transmitente;

V - do início da prestação de serviços de transporte interestadual e intermunicipal, de qualquer natureza;

VI - do ato final do transporte iniciado no exterior;

VII - das prestações onerosas de serviços de comunicação, feita por qualquer meio, inclusive a geração, a emissão, a recepção, a transmissão, a retransmissão, a repetição e a ampliação de comunicação de qualquer natureza;

VIII - do fornecimento de mercadoria com prestação de serviços:

a) não compreendidos na competência tributária dos Municípios;

b) compreendidos na competência tributária dos Municípios e com indicação expressa de incidência do imposto de competência estadual, como definido na lei complementar aplicável;

IX - do desembaraço aduaneiro de mercadorias ou bens importados do exterior;

$\mathrm{X}$ - do recebimento, pelo destinatário, de serviço prestado no exterior;

XI - da aquisição em licitação pública de mercadorias ou bens importados do exterior e apreendidos ou abandonados;

XII - da entrada no território do Estado de lubrificantes e combustíveis líquidos e gasosos derivados de petróleo e energia elétrica oriundos de outro Estado, quando não destinados à comercialização ou à industrialização;

XIII - da utilização, por contribuinte, de serviço cuja prestação se tenha iniciado em outro Estado e não esteja vinculada a operação ou prestação subseqüente.

$\S 1^{\circ} \mathrm{Na}$ hipótese do inciso VII, quando o serviço for prestado mediante pagamento em ficha, cartão ou assemelhados, considera-se ocorrido o fato gerador do imposto quando do fornecimento desses instrumentos ao usuário.

$\S 2^{\circ} \mathrm{Na}$ hipótese do inciso IX, após o desembaraço aduaneiro, a entrega, pelo depositário, de mercadoria ou bem importados do exterior deverá ser autorizada pelo órgão responsável pelo seu desembaraço, que somente se fará mediante a exibição do comprovante de pagamento do imposto incidente no ato do despacho aduaneiro, salvo disposição em contrário.

$\S 3^{\circ} \mathrm{Na}$ hipótese de entrega de mercadoria ou bem importados do exterior antes do desembaraço aduaneiro, considera-se ocorrido o fato gerador neste momento, devendo a autoridade responsável, salvo disposição em contrário, exigir a comprovação do pagamento do imposto.

169 MARIANO, Antonio Paulo; WERNECK, Raphael; BEZERRA, Sandra Regina Alencar. Substituição Tributária no ICMS: aspectos jurídicos e práticos. São Paulo: IOB, 2009, p. 30.

170 Ibid., loc. cit. 
Atendidas essas exigências, os regimes de substituições tributárias "para trás" e concomitante não poderão ser questionados. O mesmo não se pode afirmar no que se refere à substituição tributária "para frente".

Nessa modalidade, conforme já afirmado acima, atribui-se à terceira pessoa a responsabilidade por obrigação tributária de fato gerador futuro, ou seja, que ainda não tenha ocorrido. A cobrança do tributo é antecipada. Significa afirmar que há uma presunção de ocorrência de um fato futuro:

[...] consiste em obrigar outrem a pagar, não apenas o imposto atinente à operação por ele praticada, mas também, o relativo à operações posteriores.

Fica explícito, nessa hipótese dois fenômenos de ordem estritamente fictícia: de um lado, considera-se nascida uma obrigação tributária antes mesmo da ocorrência do fato in concreto, que justifica a sua existência e, de outro lado, atribui-se a responsabilidade, relativa a essa obrigação, a uma terceira pessoa que, não participou, nem participará, efetivamente, do referido fato imponível, que, como dito, ainda nem mesmo aconteceu. ${ }^{171}$

E justamente por estabelecer a possibilidade de tributação de fato que ainda não ocorreu, e que pode não ocorrer, é que esse regime deve ser considerado inconstitucional, por ofensa ao princípio da tipicidade e da segurança jurídica.

Tais princípios constitucionais exigem que, para a cobrança do tributo, tenham ocorrido os pressupostos necessários ao surgimento da obrigação tributária ${ }^{172}$, com a subsunção do fato à norma. Para que nasça a obrigação tributária, de acordo com o princípio da tipicidade, é necessária a ocorrência real e efetiva do fato imponível ${ }^{173}$ :

O princípio da tipicidade impõe que o tributo só seja exigido quando se realiza, no mundo fenomênico, o pressuposto de fato a cuja ocorrência a lei vincula o nascimento da obrigação tributária, Dito de outra maneira, o tributo só pode ser validamente exigido quando nasceu por vontade de

\footnotetext{
${ }^{171}$ MARIANO, Antonio Paulo; WERNECK, Raphael; BEZERRA, Sandra Regina Alencar. Substituição Tributária no ICMS: aspectos jurídicos e práticos. São Paulo: IOB, 2009, p. 58.

172 CARRAZZA, Roque Antonio. ICMS. 15. ed., rev. e ampl. até a EC 67/2011, de acordo com a Lei Complementar 87/1996 com suas ulteriores modificações. São Paulo: Malheiros, 2011, p. 355.

173 Op. cit., p. 357.
} 
lei. Se não se realiza o fato imponível tributário (fato gerador in concreto), isto é, se não se cumprem integralmente os elementos do suposto de fato legal (sempre minucioso, de modo a permitir que o contribuinte calcule antecipadamente a carga tributária que terá o dever de suportar), o lançamento e a arrecadação do tributo serão inválidos. ${ }^{174}$

Nem se alegue que o fato de o parágrafo $7^{\circ}$ do artigo 150 da Constituição Federal assegurar a imediata e preferencial restituição da quantia paga, caso não se realize o fato gerador presumido, legitima a cobrança antecipada, conforme Schoueri destaca o entendimento do STF: “Tais argumentos não vêm sendo acolhidos pelo Supremo Tribunal Federal. Entende-se, ao contrário, que não há qualquer óbice à substituição, desde que, não ocorrendo o fato jurídico tributário, seja assegurada a imediata e preferencial restituição do tributo devido". ${ }^{175}$

Ao tratar da restituição, o artigo 10 da Lei Complementar nº 87/96 determina:

Art. 10. É assegurado ao contribuinte substituído o direito à restituição do valor do imposto pago por força da substituição tributária, correspondente ao fato gerador presumido que não se realizar.

$\S 1^{\circ}$ Formulado o pedido de restituição e não havendo deliberação no prazo de noventa dias, o contribuinte substituído poderá se creditar, em sua escrita fiscal, do valor objeto do pedido, devidamente atualizado segundo os mesmos critérios aplicáveis ao tributo.

$\S 2^{\circ} \mathrm{Na}$ hipótese do parágrafo anterior, sobrevindo decisão contrária irrecorrível, o contribuinte substituído, no prazo de quinze dias da respectiva notificação, procederá ao estorno dos créditos lançados, também devidamente atualizados, com o pagamento dos acréscimos legais cabíveis.

Ou seja, o procedimento de restituição regulamentado pela Lei Kandir não assegura a "imediata e preferencial restituição", ao contrário, ao condicionar o direito do contribuinte a apresentar um pedido e conceder um prazo de 90 dias para as autoridades

174 CARRAZZA, Roque Antonio. Curso de Direito Constitucional Tributário. 19. ed., rev. e ampl. até a EC 39/2002. São Paulo: Malheiros, 2003, p. 459.

175 SCHOUERI, Luis Eduardo. Direito Tributário. São Paulo: Saraiva, 2011, p. 485. 
analisarem o pedido, "distorceu o comando constitucional (artigo 150, $\S 7^{\circ}$ ), tornando a 'restituição' distante e não preferencial" ${ }^{\prime 176}$.

Aroldo Gomes de Matos também critica o procedimento imposto pela lei complementar:

Transformar a cláusula 'imediata e preferencial' num prazo elástico e extensivo de 90 dias ao infinito, além de ser uma infeliz e serôdia inovação, é desmantelar o próprio comando regrado, tornando o 'positivo da Constituição em negativo', numa grosseira inversão à imagem de retórica criada por Ives Gandra da Silva Martins.

$[\ldots]$

Nessas condições, o que era para ser restituído de forma 'imediata e preferencial', por força de emenda constitucional, passará a ser 'distante, mediato e ambíguo', por força de lei complementar reguladora, o que é inadmissível. ${ }^{17}$

No mesmo sentido, são os ensinamentos de Misabel Abreu Machado Derzi:

Ora, o imediatismo da restituição estabelecido no $\S 7^{\circ}$ do art. 150 (na redação da Emenda Constitucional), somente se concilia com o cotejo automático de créditos e débitos inerente ao regime de compensação por período de ICMS. Na verdade, a título de regulamentar a cláusula da imediata e preferencial restituição, a Lei Complementar $n^{\circ} 87 / 96$ criou empecilhos que, inconstitucionalmente, a transformam em mediata restituição. ${ }^{178}$

Ademais, a lei complementar não garante o direito de devolução em moeda, mas, sim, o lançamento na escrita fiscal de créditos correspondentes ao ICMS recolhido a maior, para compensação com débitos do ICMS. ${ }^{179}$

176 CARRAZZA, Roque Antonio. ICMS. 15. ed., rev. e ampl. até a EC 67/2011, de acordo com a Lei Complementar 87/1996 com suas ulteriores modificações. São Paulo: Malheiros, 2011, p. 363.

177 MATTOS, Aroldo Gomes de. ICMS - Substituição tributária 'para frente' e a Lei Complementar 87/1996, art. 10. In: ROCHA, Valdir de Oliveira. O ICMS e a Lei Complementar 87/1996. São Paulo: Dialética, 1996, p. 27-28.

178 BALEEIRO, Aliomar. Direito tributário brasileiro. Atualizada por Misabel Abreu Derzi. Rio de Janeiro: Forense, 2005, p. 450.

179 CARRAZZA, op. cit., p. 365. 
Ocorre que, em algumas situações, o contribuinte não tem como compensar esses créditos, uma vez que não há débitos de ICMS ou os créditos são superiores aos débitos. É o caso, por exemplo, de empresas exportadoras, que geralmente acumulam créditos, uma vez que suas operações de saída não são tributadas. ${ }^{180}$ Não havendo débitos, não há como compensar eventuais créditos de restituição de substituição tributária (especialmente porque essas empresas já acumulam créditos em operações normais).

Também nas eventuais vendas com prejuízos, o contribuinte não conseguirá compensar os créditos excedentes, tendo que aguardar a realização de vendas com lucro para efetuar a compensação, o que pode demorar. ${ }^{181}$ Por fim, o contribuinte tampouco conseguirá ser ressarcido, no caso de encerramento de suas atividades. ${ }^{182}$

Além disso, deve ser observado que a base de cálculo de qualquer tributo, inclusive do ICMS, deve ter relação com a materialidade da hipótese de incidência tributária. Na substituição tributária, entretanto, a base de cálculo é ficta e estimada em pautas fiscais, valores de tabelas estimadas. A fixação do valor do tributo a ser pago nesse sistema constitui mais uma ofensa ao princípio da tipicidade, uma vez que o contribuinte não pagará o montante do imposto devido pela ocorrência do fato gerador, ou seja, não guardará exata relação com o valor real da operação mercantil se esta, de fato, ocorrer. ${ }^{183}$

Há, ainda, ofensa ao princípio da não cumulatividade.

Isso porque, ao antecipar o pagamento do tributo incidente nas operações subsequentes, o substituto não poderá se beneficiar do direito de crédito garantido pela não cumulatividade. ${ }^{184}$ Christine Mendonça, ao tratar da desobediência à não cumulatividade, destaca:

Se a cadeia tributável pelo ICMS em que ocorre a substituição tributária, portanto, for formada tão-só por três pessoas (dois contribuintes, apenas

\footnotetext{
${ }^{180}$ CARRAZZA, Roque Antonio. ICMS. 15. ed., rev. e ampl. até a EC 67/2011, de acordo com a Lei Complementar 87/1996 com suas ulteriores modificações. São Paulo: Malheiros, 2011, p. 365.

181 Ibid., p. 366.

182 Ibid., loc. cit.

183 Ibid., p. 369.

184 Ibid., p. 371.
} 
um substituído) não há nenhuma desobediência ao procedimento constitucional para se alcançar a não-cumulatividade do ICMS, uma vez que o sistema prevê o nascimento do débito do Fisco escritural antecipado. O problema está em quando, sendo mais extenso o ciclo (mais de um substituído), a legislação infraconstitucional não prevê o nascimento do débito do Fisco escritural para os demais substituídos, pois também estes últimos realizam o evento necessário para o nascimento do débito do Fisco escritural do ICMS. ${ }^{185}$

Outra possibilidade de ofensa à não cumulatividade é a fixação da pauta fiscal superior ao valor real da operação. Se os valores reais forem inferiores aos valores arbitrados, deve ser assegurado o creditamento do valor excedente, sob pena de ofensa à não cumulatividade e configuração de confisco:

Se não for assegurado ao contribuinte o creditamento do valor excedente ao das operações mercantis realizadas estar-se-á, ao lado da isenção e da não incidência (art. 155, § $2^{\circ}$, II, da CF), 'criando', em berrante afronta ao Diploma Magno, mais uma restrição ao princípio da não cumulatividade do ICMS: a pauta fiscal superior à realidade. ${ }^{186}$

Se for comprovado que as pautas fiscais são superiores aos preços efetivamente praticados, deve prevalecer o preço real. Mesmo porque a tentativa de evitar a evasão fiscal e a justificativa da praticidade para instituição do regime de substituição tributária não podem se sobrepor aos princípios da segurança e a certeza da tributação "postulados constitucionais que exigem que os contribuintes recolham, a título de tributo, exatamente o que devem; nunca, mais. Do contrário haverá, da parte da pessoa política tributante, enriquecimento sem causa, que a Teoria Geral do Direito repele e o senso comum inadmite."187

Por fim, a substituição tributária, embora seja adotada pera evitar a sonegação, o que contribui para a livre concorrência, pode ofender o princípio da capacidade contributiva e a própria concorrência. Schoueri destaca a justificativa para aplicação do regime:

185 MENDONÇA, Christine. A Não-Cumulatividade do ICMS. São Paulo: Quartier Latin, 2005, p. 248.

${ }^{186}$ CARRAZZA, Roque Antonio. ICMS. 15. ed., rev. e ampl. até a EC 67/2011, de acordo com a Lei Complementar 87/1996 com suas ulteriores modificações. São Paulo: Malheiros, 2011, p. 379.

187 Ibid., p. 376-377. 


\begin{abstract}
Nesse sentido, a substituição tributária enquanto técnica que visa a facilitar a arrecadação, fiscalização e a coibir a evasão, surgiu também com o intuito de assegurar a concorrência, na medida em que busca anular as vantagens concorrenciais desfrutadas por aqueles que se furtam ao pagamento de tributos. Desta forma, em princípio, a substituição tributária poderia ser encarada como um instrumento tributário que realiza a concorrência, ao evitar que a evasão fiscal conduza a distorções, prejudicando concorrentes no mercado. Fundamenta-se, assim, tanto na necessidade de assegurar eficiência à Administração Tributária, quanto no Princípio da Livre Concorrência. ${ }^{188}$
\end{abstract}

No entanto, se as pautas fiscais e a tributação presumida do regime de substituição tributária são aplicadas de forma desvirtuada, distorcida, com valores excessivos, em vez de beneficiar a concorrência, haverá uma interferência negativa na formação dos preços, configurando ofensa ao princípio da capacidade contributiva e da livre-concorrência. ${ }^{189}$

Nesse caso, o empresário mais eficiente, que conseguir reduzir o preço da sua mercadoria, repassará ao consumidor o mesmo valor do tributo que outros empresários menos eficientes, que praticam preços superiores. ${ }^{190}$ Ou seja, além de ofender a capacidade contributiva do consumidor (que pagará o mesmo valor de tributo ainda que adquira a mercadoria de preço inferior), há uma punição para o empresário mais eficiente, representando ofensa à livre-concorrência. ${ }^{191}$

Outro exemplo é o caso de operações em que o adquirente está localizado em Estado que aplica o regime de substituição tributária, que não é adotado por outros Estados. ${ }^{192}$ Se a operação se efetuar com fornecedor do Estado em que tem a substituição tributária, haverá aplicação de preços presumidos, que podem ser superiores ao preço efetivamente praticado. ${ }^{193}$ Se a operação for realizada com fornecedor de outro Estado, que não aplica o regime, a base de cálculo do ICMS corresponderá ao exato valor da

\footnotetext{
188 SCHOUERI, Luis Eduardo. Direito Tributário. São Paulo: Saraiva, 2011, p. 486.

189 Ibid., p. 486.

190 Ibid., p. 487.

191 Ibid., loc. cit.

192 Ibid., loc. cit.

193 Ibid., loc. cit.
} 
mercadoria, o que beneficiará o adquirente, já que a "carga tributária incidente na saída de tal produto não estará distorcida pelas bases presumidas impostas por este regime"194.

Resumidamente, não se pode admitir que, a pretexto de combater a evasão fiscal, facilitar a fiscalização e aumentar a arrecadação, os Estados utilizem o regime de substituição tributária "para frente", ofendendo princípios e garantias constitucionais.

\subsection{Restrições Constitucionais ao Princípio da Não Cumulatividade}

Definimos até o momento como a Constituição Federal garantiu o direito ao crédito de ICMS, de forma ampla e sem restrições.

Ocorre, entretanto, que a própria Constituição Federal restringe esse direito. Há no artigo 155 da Carta Magna duas hipóteses que reduzem o direito de crédito:

$\S 2 .^{\circ} \mathrm{O}$ imposto previsto no inciso II atenderá ao seguinte:

I - será não-cumulativo, compensando-se o que for devido em cada operação relativa à circulação de mercadorias ou prestação de serviços com o montante cobrado nas anteriores pelo mesmo ou outro Estado ou pelo Distrito Federal;

II - a isenção ou não-incidência, salvo determinação em contrário da legislação:

a) não implicará crédito para compensação com o montante devido nas operações ou prestações seguintes;

b) acarretará a anulação do crédito relativo às operações anteriores;

Da análise do Texto Constitucional conclui-se que apenas a isenção e não incidência tem o condão de restringir, reduzir ou amesquinhar o direito de crédito de ICMS, o princípio da não cumulatividade.

Constitucionalmente, a não cumulatividade foi específica e expressamente concedida de forma irrestrita, exceto nos casos de vedação de crédito em operações que

194 SCHOUERI, Luis Eduardo. Direito Tributário. São Paulo: Saraiva, 2011, p. 487. 
envolvem isenção e não incidência. Este é um rol taxativo: tão somente essas operações restringem o direito de crédito.

Essas são as únicas exceções ao direito de crédito previsto na Constituição Federal: isenção e não incidência. Os demais créditos devem ser aproveitados. Se o Constituinte tivesse a intenção de restringir ainda mais o direito de crédito, a Constituição disporia expressamente sobre as outras situações que restringiriam tal direito. ${ }^{195}$

Sendo uma criação constitucional e não legal, não há como negar que eventual restrição à não cumulatividade só pode estar prevista na própria Constituição Federal, não se admitindo redução ou supressão de seu significado, conteúdo ou alcance pelo legislador.

Assim, legislação ordinária ou complementar não pode modificar o sistema de apuração da não cumulatividade previsto na Constituição Federal. As únicas restrições estão previstas na própria Constituição. Exceto nesses casos, o direito de crédito é amplo e irrestrito.

Nas palavras de Carrazza:

Operando sobre uma base constitucional, o legislador - como vimos e revimos - não pode manipular livremente o alcance do princípio da não cumulatividade. Daí serem inconstitucionais as restrições legislativas ao pleno desfrute do direito de crédito do ICMS.

Reafirmamos que nem mesmo a lei complementar pode criar obstáculos ou, de alguma maneira, inovar na regulação deste direito, que foi exaustivamente disciplinado pelo próprio Texto Magno.

Noutros termos, a lei complementar ao 'disciplinar o regime de compensação do imposto', não pode interferir no conteúdo e no alcance do princípio da não cumulatividade do ICMS. ${ }^{196}$

Destaque-se, ademais, que as próprias restrições constitucionais têm efeitos nocivos sobre a tributação, apresentando traços de cumulatividade. ${ }^{197}$ Isso porque, se a isenção ou

195 TEIXEIRA, Alessandra Machado Brandão. A Tributação sobre o Consumo de Bens e Serviços. Belo Horizonte: Mandamentos, 2002, p. 207.

196 CARRAZZA, Roque Antonio. ICMS. 15. ed., rev. e ampl. até a EC 67/2011, de acordo com a Lei Complementar 87/1996 com suas ulteriores modificações. São Paulo: Malheiros, 2011, p. 437. 
não incidência ocorrer no meio da cadeia produtiva, não será possível compensar o imposto eventualmente pago nas operações anteriores. Dessa forma, o imposto anteriormente pago ficará perdido, não podendo ser utilizado se, por acaso, surgir uma operação posterior tributada $^{198}$ :

\begin{abstract}
A concessão de isenções intercorrentes (no meio do ciclo produtivo ou comercial) gera cumulatividade, terminando o Estado por arrecadar mais do que arrecadaria, caso não houvesse isenção. Esse fenômeno ocorre, tendo em vista que o operador isento, caso não houvesse isenção, poderia creditar do imposto pago nas aquisições, podendo abatê-lo dos débitos porventura existentes. Havendo isenção simples, ele não pode aproveitar os créditos das aquisições e o imposto pago nesse momento integrará definitivamente o seu custo de produção, sendo repassado imediatamente para o preço do produto, o que acarreta um aumento do preço por questões fiscais, e não por razões de mercado. ${ }^{199}$
\end{abstract}

Afirma-se que, para evitar que tais efeitos fossem ainda mais prejudiciais por conta da cumulatividade autorizada na Constituição Federal, o legislador constituinte condicionou a concessão das isenções à previsão em legislação complementar ou instituição por convênios celebrados pelos Estados, a fim de que os benefícios fossem aplicados de forma harmônica no território nacional. Dessa forma, evitar-se-ia a concessão de isenções por cada Estado, com base em critérios próprios, o que poderia ofender ainda mais a neutralidade na tributação. ${ }^{200}$

\title{
3.4 Alcance da lei Complementar no que Concerne ao Princípio da Não CUMUlatividade
}

Como visto acima, as únicas restrições ao princípio da não cumulatividade estão previstos na própria Constituição Federal. O Constituinte, ao contrário do que acontecia nas redações das Constituições anteriores, na Carta Magna de 1988, optou por traçar minuciosamente as características da técnica não cumulativa aplicável ao ICMS.

\footnotetext{
197 TEIXEIRA, Alessandra Machado Brandão. A Tributação sobre o Consumo de Bens e Serviços. Belo Horizonte: Mandamentos, 2002, p. 218.

198 SCHOUERI, Luis Eduardo. Direito Tributário. São Paulo: Saraiva, 2011, p. 370.

199 TEIXEIRA, op. cit., p. 223.

200 Ibid., p. 221.
} 
Não obstante, as Leis Complementares que regulamentam a matéria estabeleceram uma série de restrições: consumo de energia elétrica por estabelecimentos referentes a custos indiretos (Leis Complementares $\mathrm{n}^{\mathrm{o}} \mathrm{s}$ 102/2000 e 114/2002), bens para o ativo imobilizado (Lei Complementar $\mathrm{n}^{\circ} 102 / 2000$ ), nota fiscal com irregularidades formais (Lei Complementar $\mathrm{n}^{\circ}$ 87/96) e ineficácia do crédito fiscal atribuído ao estabelecimento recebedor de mercadoria quando não observada a Lei Complementar $n^{\circ}$ 24/75.

A legalidade de tais restrições é defendida com base no artigo 155, XII, alínea $c$, da Constituição Federal, que dispõe que cabe à lei complementar disciplinar o regime de compensação do imposto.

Mas o referido dispositivo constitucional autoriza, de fato, a mitigação do princípio da não cumulatividade delineada de forma detalhada na Carta Magna? Qual foi a intenção do Constituinte ao conceder poder ao legislador complementar para tratar da não cumulatividade do ICMS?

Ora, conforme exposto acima, a Constituição Federal foi minuciosa e exaustiva ao traçar o perfil da não cumulatividade, atribuindo absoluto direito ao crédito, exceto nos casos de isenção e não incidência, não cabendo à legislação complementar, até por uma questão de hierarquia das leis, estabelecer restrições abusivas e que tornam o imposto cumulativo. $^{201}$ Até porque, se o legislador constituinte tivesse a intenção de impor outras restrições ao direito ao crédito do ICMS, teria o feito na própria Constituição Federal.

Na verdade, as normas da não cumulatividade previstas na Constituição Federal possuem eficácia plena e aplicabilidade imediata. ${ }^{202}$

O artigo 155, XII, alínea $c$, da Constituição Federal autoriza a legislação complementar apenas a missão de disciplinar, instruir os procedimentos para apurar regime

201 MATTOS, Aroldo Gomes de. A cumulatividade do ICMS. Revista Tributária e de Finanças Públicas, São Paulo: Revista dos Tribunais, ano 15, n. 72, jan.-fev. 2007, p. 25.

202 BRITO, Edvaldo Pereira de. ICMS: inconstitucionalidade da pauta fiscal. In: ROCHA, Valdir de Oliveira (Org.). Grandes Questões atuais de direito tributário. São Paulo: Dialética, 2005, p. 92. 
de compensação, já delineado na Carta Magna. ${ }^{203}$ Não pode interferir no conteúdo ou no alcance da regra constitucional da não cumulatividade: “deve, apenas, operacionalizar documentalmente um sistema de escrituração em que, considerado certo lapso de tempo, é registrado, de um lado, o imposto devido e, de outro, a expressão financeira do abatimento correspondente". ${ }^{204}$

Nesse sentido, José Eduardo Soares de Melo:

À lei complementar cabe, exclusivamente, 'disciplinar o regime de compensação de imposto' (artigo 155, XII, c), isto é, estabelecer um procedimento que objetive operacionalizar a sistemática não cumulatividade; jamais torpedeá-lo ou limitar, restringir ou cercear os direitos públicos subjetivos (constitucionais), erigidos como um autêntico estatuto do contribuinte.

A lei complementar objetiva explicitar a norma constitucional, caracterizando-se como lei nacional que fundamenta, inspira e permeia as legislações federal, estadual e municipal, não possuindo efetivo caráter inovatório, mas meramente regulatório, tornando claros, práticos e operacionais os comandos constitucionais. ${ }^{205}$

Ou seja, a lei complementar trata somente da forma de execução do regime de compensação, disciplina o procedimento de constituição, registro e utilização do crédito do ICMS. Não pode, contudo, impor nenhuma restrição ao direito de crédito, nem mesmo ampliá-lo.

Resumidamente, concluímos que a não cumulatividade é a técnica de tributação definida na Constituição Federal para o ICMS, de forma minuciosa e que não pode ser limitada pela legislação infraconstitucional.

203 MATTOS, Aroldo Gomes de. A cumulatividade do ICMS. Revista Tributária e de Finanças Públicas, São Paulo: Revista dos Tribunais, ano 15, n. 72, jan.-fev. 2007, p. 26.

204 CARRAZZA, Roque Antonio. ICMS. 15. ed., rev. e ampl. até a EC 67/2011, de acordo com a Lei Complementar 87/1996 com suas ulteriores modificações. São Paulo: Malheiros, 2011, p. 437.

205 MELO, José Eduardo Soares de. Questões. Revista de Direito Tributário, São Paulo, v. 64, 1994, p. 302. 


\section{O ICMS NO CONTEXTO DA GUERRA FISCAL}

Traçadas as premissas do perfil do ICMS na Constituição Federal, especialmente no que se refere à técnica da não cumulatividade, passaremos a tratar das distorções do ICMS causadas pela guerra fiscal entre os Estados.

\subsection{SistemAS FEDERADOS}

A forma federativa de Governo teve origem na América do Norte, em virtude dos conflitos decorrentes da exigência de impostos que surgiram entre a Inglaterra e as suas 13 colônias, em 1773, e que resultaram na Independência dos Estados Unidos, em 4 de julho de $1776 .^{206}$

Inicialmente, as colônias uniram-se numa confederação, tendo, posteriormente, com a Constituição aprovada em 1787, na Filadélfia, passado à forma federativa. ${ }^{207}$

Não havia a intenção deliberada de criar uma forma de Estado Federativo, mas a preocupação de reforçar o Estado nacional e sua soberania, sem, no entanto, atingir os governos locais de cada colônia. ${ }^{208}$ Assim, criou-se uma estrutura de divisão de poderes governamentais entre o governo nacional e os governos locais, no modelo atualmente conhecido, que, no decorrer do tempo, foi sendo adequado às especificidades de cada país que o adota.

Nelson de Freitas Porfírio Junior destaca que não é simples, entretanto, a definição dos limites entre os poderes nacionais e os regionais, sendo isto um dos maiores problemas enfrentados pelo federalismo. ${ }^{209}$

\footnotetext{
206 OLIVEIRA, Regis Fernandes de. Curso de Direito Tributário. São Paulo: Revista dos Tribunais, 2006, p. 25.

207 Ibid., p. 25.

${ }^{208}$ PORFIRIO JUNIOR, Nelson de Freitas. Federalismo, Tipos de Estado e Conceito de Estado Federal. In: CONTI, José Mauricio Conti (Org.). Federalismo Fiscal. Barueri, SP: Manole, 2004, p. 5.

${ }^{209}$ Ibid., p. 6.
} 
É Federal aquele Estado formado basicamente por uma aliança ou união de Estados, sem que estes sejam soberanos. A soberania compete ao Estado Federal.

O exercício do poder político, em uma forma federativa, permite a coexistência de diferentes entes, que integram um ente maior, o Federal, detentor da soberania, mas que atribui diversos graus de autonomia aos seus membros. ${ }^{210}$

O elemento nuclear da federação é a coordenação de diversas ordens jurídicas sobre um mesmo Estado nacional, cada qual no âmbito de competências previamente definidas. A autonomia de cada ente do Estado Federal protege a ordem jurídica total, garantindo um sistema jurídico e político integrado. ${ }^{211}$

Há uma pluralidade consorciada e coordenada de diversas ordens jurídicas incidentes sobre um mesmo território estatal, com competências próprias previamente definidas, a submeter um povo. ${ }^{212}$

Nessa linha, Cármen Lúcia Antunes Rocha ${ }^{213}$ assevera:

A federação é fenômeno de Direito Interno, fundamentalmente de Direito Constitucional, caracterizando-se pela existência de uma organização política nacional sobreposta a todas as ordens que, setorialmente, conciliam-se e aplicam-se em condomínio jurídico no Estado. As entidades federadas não se qualificam pela soberania, característica exclusiva da entidade nacional. Sem soberania elas carecem do poder de sucessão, ficando restritas ao exercício de suas competências, cuja descrição é constitucionalmente estabelecida. O modelo de repartição dessas competências é que traça o modelo da Federação escolhido em cada Estado.

Verifica-se, portanto, que são elementos indispensáveis para diferenciar um Estado Federado de um Estado centralizado soberania, autonomia e competência.

${ }^{210}$ ELALI, André. O Federalismo Fiscal Brasileiro e o Sistema Tributário Nacional. São Paulo: MP Editora, 2005, p. 18.

211 REIS, Elcio Fonseca. Federalismo Fiscal: competência concorrente e normas gerais de direito tributário. Belo Horizonte: Mandamentos, 2000, p. 32.

212 Ibid., loc. cit.

213 ROCHA, Carmen Lúcia Antunes. República e Federação no Brasil - Traços constitucionais da organização política brasileira. Belo Horizonte: Del Rey, 1997, p. 176. 
Mas é preciso fixar que não há um modelo único de federação, cabendo a cada Estado delimitar o modelo político que adotará. Dessa forma, André Elali conclui:

\begin{abstract}
A primeira percepção necessária para um melhor entendimento do significado de federalismo, é a de que não há, para designar sua essência, 'um conceito estático, amarrado a determinadas coordenadas históricas'. Isto porque cada Estado adota, em verdade, um modelo peculiar, pertinente às suas circunstâncias, que varia em face de vários elementos, conforme mencionado anteriormente. ${ }^{214}$
\end{abstract}

Assim, o Estado Federal pode ser formado por agregação ou por desagregação.

No primeiro caso, há a reunião de Estados preexistentes, que renunciam a sua soberania em benefício do Estado nacional que está se formando (força centrípeta). Exemplos de Estados Federados formados por agregação são os Estados Unidos, a Suíça e a Alemanha.

Na segunda possibilidade, já há um Estado unitário que opta, por razões políticas, econômicas etc., por um processo de descentralização, com a criação de novos entes dotados de autonomia política (força centrífuga). Exemplos de Estados em que a forma federativa decorreu do deslocamento de poderes de um Estado unitário e centralizado para coletividades inferiores são o Brasil, México e Áustria.

O Estado Federal pode ser, ainda, dividido nas seguintes espécies (i) dualista, (ii) cooperativo e (iii) integrativo.

Na Federação dualista, tipo original dessa forma de Estado e mais característico das federações formadas por agregação, há uma repartição horizontal de competências, na qual existem duas esferas de poder nitidamente distintas com atribuições e competência próprias, ou seja, existência de duas soberanias: Estado Federal e Estados-membros.

214 ELALI, André. O Federalismo Fiscal Brasileiro e o Sistema Tributário Nacional. São Paulo: MP Editora, 2005, p. 18. 
Esta forma de federalismo, inicialmente existente na federação norte-americana, foi, no entanto, sendo substituída pelo sistema cooperativo, que passou a predominar a partir de 1930, após a grave crise econômica de $1929 .^{215}$

A Federação cooperativa não dispõe de fronteiras rígidas no que se refere à repartição de competências, como ocorre no modelo dualista. É baseada na coordenação de todas as competências dirigidas pelo Estado Federal. Enfatiza o trabalho conjunto e harmônico do governo central com os Estados-membros para resolver os problemas do país. $^{216}$ Há a exclusão da soberania, com a concessão de competências residuais aos Estados-membros. $^{217}$

Por último, na forma integrativa, os Estados-membros estão sujeitos à intervenção do Estado Federal, com o objetivo de alcançar maior eficiência. Neste caso, destaca-se o risco de formar um Estado unitário constitucionalmente descentralizado, em prejuízo, inclusive, da própria forma federativa. ${ }^{218}$

Não há, portanto, um conceito universal de Federação, inexistindo dois ou mais Estados Federais integralmente idênticos.

Confirmando-se que é possível encontrar diversas formas de federação, cabendo a cada Estado definir individualmente o modelo que pretende adotar, adaptando-o às suas peculiaridades política, cultural e histórica, ao se analisar os entendimentos doutrinários sobre os pressupostos necessários para a existência de um Estado, verifica-se que há diversas correntes. Nelson de Freitas Porfírio Júnior destaca os ensinamentos de quatro grandes doutrinadores.

215 ZIMMERMANN, Augusto. Teoria Geral do Federalismo Democrático. 2. ed. Rio de Janeiro: Lúmen Júris, 2005, p. 56-57.

216 PORFIRIO JUNIOR, Nelson de Freitas. Federalismo, Tipos de Estado e Conceito de Estado Federal. In: CONTI, José Mauricio Conti (Org.). Federalismo Fiscal. Barueri, SP: Manole, 2004, p. 9.

217 OLIVEIRA, Regis Fernandes de. Curso de Direito Tributário. São Paulo: Revista dos Tribunais, 2006, p. 27.

218 PORFIRIO JUNIOR, op. cit., p. 10. 
Cita, primeiramente, Michel Temer, para quem é necessária a rigidez constitucional e a existência de um órgão constitucional que exerça o controle de constitucionalidade das leis para que se tenha efetivamente um Estado com estrutura federal. ${ }^{219}$

Carlos Velloso, por sua vez, visualiza os seguintes princípios como pressupostos para uma Federação: 1) repartição de competências constitucionais; 2) autonomia dos Entes Federados (auto-organização, autogoverno, e autoadministração); 3) participação dos Estados-membros na organização e na formação da vontade da Federação; 4) discriminação constitucional das rendas tributárias, com a repartição da competência tributária e a distribuição da receita tributária. ${ }^{220}$

Geraldo Ataliba enumera os seguintes requisitos para uma estrutura federativa: a) existência de uma Constituição Federal rígida, para garantir a estabilidade do Estado; b) presença de poder constituinte próprio nos Estados-membros; c) território próprio; d) conjunto de cidadãos (povo) próprio; e) repartição constitucional de competências entre os Estados-membros; f) dois órgãos legislativos federais (bicameralismo), um integrado por representantes do povo, eleitos proporcionalmente à população, e outro integrado paritariamente por representantes dos Estados-membros; g) corte constitucional paritariamente por representantes dos Estados-membros. ${ }^{221}$

Por fim, Dalmo Dallari cita como pressupostos necessários: a) perda da condição de Estado pelos Estados-membros; b) Constituição Federal (e não um tratado) como base jurídica do Estado; c) inexistência de direito de secessão, por proibição constitucional (explícita ou não); d) soberania apenas do Estado Federal; e) distribuição de competências pela Constituição Federal ao Estado Federal e as unidades federadas; f) renda própria destinada a cada ente da Federação; g) compartilhamento de poder político entre a União e

${ }^{219}$ PORFIRIO JUNIOR, Nelson de Freitas. Federalismo, Tipos de Estado e Conceito de Estado Federal. In: CONTI, José Mauricio Conti (Org.). Federalismo Fiscal. Barueri, SP: Manole, 2004, p. 7.

220 Ibid., loc. cit.

221 Ibid., loc. cit. 
as unidades federadas, por meio de órgãos representativos destas e da população; e

h) existência de uma única cidadania nacional, que é a do Estado Federal. ${ }^{222}$

André Elali destaca que a análise dos pontos que caracterizam a Federação auxilia no entendimento da questão, mas deve-se tomar o cuidado de não vincular uma estrutura federativa a um ou outro modelo, pois, como exposto acima, cada Estado federativo adota um modelo adequado às suas características próprias. ${ }^{223}$

Nesse contexto, considerando-se que cada país adéqua o sistema federativo às suas expectativas e necessidades próprias e após expostos neste subitem, os tipos, formas e características básicas do federalismo, passaremos a abordar o sistema adotado pelo Brasil.

\subsection{O Sistema FEDERAdo Brasileiro}

Conforme já esclarecido, no Brasil, o federalismo nasceu de um movimento centrífugo.

Inicialmente Colônia de Portugal, o Brasil passou a ser Reino Unido ao de Portugal e Algarves, no período de 1815 a 1822 e, posteriormente, a sede imperial. ${ }^{224}$ Durante todo esse período, em que se tiveram as Capitanias Hereditárias, o Governo Geral e o ViceReinado, sempre foi mantido o unitarismo das ordens. ${ }^{225}$

Ainda depois da Proclamação da Independência, em 1822, manteve-se o modelo unitarista. A Constituição de 1824, no Império, concentrou todos os poderes no Imperador, limitando a atuação das províncias. ${ }^{226}$

${ }^{222}$ PORFIRIO JUNIOR, Nelson de Freitas. Federalismo, Tipos de Estado e Conceito de Estado Federal. In: CONTI, José Mauricio Conti (Org.). Federalismo Fiscal. Barueri, SP: Manole, 2004, p. 8.

${ }^{223}$ ELALI, André. O Federalismo Fiscal Brasileiro e o Sistema Tributário Nacional. São Paulo: MP Editora, 2005, p. 23.

224 OLIVEIRA, Regis Fernandes de. Curso de Direito Tributário. São Paulo: Revista dos Tribunais, 2006, p. 27.

225 Ibid., loc. cit.

226 Ibid., loc. cit. 
O Ato Adicional de 1834 pretendeu flexibilizar o modelo concentrador da Constituição de 1824, passando a prever a autonomia política das Províncias. ${ }^{227}$ Em 1935, a Lei $n^{\circ} 99$ introduziu a autonomia financeira das Províncias, dispondo sobre as fontes fiscais dos entes e os autorizando a fixar as suas despesas. Entretanto, a Lei de Interpretação $\mathrm{n}^{\circ} 105$, de 1840 , eliminou as inovações trazidas. ${ }^{228}$

Com o advento da República dos Estados Unidos do Brasil, em 1889, houve, finalmente, a conversão em federalismo, partindo-se de um Estado centralizado para um modelo descentralizado. ${ }^{229}$

Ou seja, a Federação Brasileira nasceu de cima para baixo, com a divisão do Estado unitário. $^{230}$ Nesse momento, foi efetuada a transformação das Províncias em Estados, reconhecendo-se, ainda, a autonomia dos Municípios, apesar de não indicar os impostos que seriam de sua competência, o que ficou atribuído à Constituição Estadual. ${ }^{231} \mathrm{~A}$ Constituição de 1891 trouxe um regime de competências e repartição de receitas divididas entre a União e os Estados-membros, mas o sistema tributário tinha uma natureza elástica, já que o legislador ordinário tinha ampla liberdade para a instituição e criação de tributos que não integravam o texto constitucional. Permitia-se, ademais, o exercício de competência concorrente, o que poderia resultar em uma bitributação. ${ }^{232}$

A Constituição de 1934, por sua vez, definiu os tributos da União, dos Estados e também dos Municípios, ou seja, referidos entes passaram a ter autonomia financeira. Definiu-se, ainda, que, nos casos de competência concorrente, prevaleceria o imposto criado pela União, em caso de bitributação. ${ }^{233}$

227 SIQUETTO, Paulo Roberto. Os projetos de reforma constitucional tributária e o federalismo Fiscal. In: CONTI, José Mauricio (Org.). Federalismo Fiscal. Barueri, SP: Manole, 2004, p. 265.

228 OLIVEIRA, Regis Fernandes de. Curso de Direito Tributário. São Paulo: Revista dos Tribunais, 2006, p. 27.

229 Ibid., loc. cit.

${ }^{230}$ CAMARGO, Guilherme Bueno. A Guerra Fiscal e seus efeitos: autonomia x centralização. In: CONTI, José Mauricio (Org.). Federalismo Fiscal. Barueri, SP: Manole, 2004, p. 194.

${ }^{231}$ SIQUETTO, op. cit., p. 266.

232 Ibid., loc. cit.

233 Ibid., loc. cit. 
Em 1937, houve um aperfeiçoamento do sistema constitucional de discriminação de rendas. No entanto, apesar de ainda haver a previsão do sistema federado,

[...] promoveu a existência de um Estado tipicamente unitário. Os entes subnacionais eram regidos pelo Decreto $\mathrm{n}^{\circ}$ 1.202, de 8 de abril de 1939. Os Estados eram governados por interventores nomeados pelo Presidente da República. As eleições tanto para o Parlamento Nacional quanto para as Assembléias Legislativas jamais foram convocadas. A natureza do regime tributário manteve-se rígida. ${ }^{234}$

A Carta de 1937, conhecida como "Polaca", imposta por Getulio Vargas, manteve a federação apenas formalmente, sujeitando-a ao Estado Novo.

A Constituição de 1946 manteve o federalismo, superando os Textos Constitucionais anteriores, ao aperfeiçoar ainda mais a matéria financeira e tributária.

Em $1^{\circ}$ de dezembro de 1965, foi promulgada a Emenda $n^{\circ} 18$, estabelecendo uma nova discriminação de rendas, com a introdução de um sistema tributário nacional efetivo. Esta emenda representa um marco, que introduziu nos aplicadores do direito a preocupação em buscar um sistema de princípios e normas tributárias que definissem definitivamente o sistema traçado na Constituição. Dessa forma, em 1966, foi editada a Lei $\mathrm{n}^{\circ} 5.712$, o Código Tributário Nacional, que introduziu as normas gerais em matéria tributária. ${ }^{235}$

A Carta de 1967 e a Emenda Constitucional de 1969 afastaram-se da forma federativa até então vigente por conter um alto grau de centralização, embora, no âmbito tributário, não tenha havido grandes alterações.

Com a atual Constituição Federal, o Estado brasileiro retornou ao conceito puro de federação, não havendo novamente grandes inovações em matéria tributária. ${ }^{236}$ Discriminou-se a distribuição de rendas de forma rígida, concedendo-se competências tributárias privativas para a União, os Estados e os Municípios.

234 SIQUETTO, Paulo Roberto. Os projetos de reforma constitucional tributária e o federalismo Fiscal. In: CONTI, José Mauricio (Org.). Federalismo Fiscal. Barueri, SP: Manole, 2004, p. 267.

235 Ibid., p. 269.

236 OLIVEIRA, Regis Fernandes de. Curso de Direito Tributário. São Paulo: Revista dos Tribunais, 2006, p. 28. 
Há repartição de competências entre a União, os Estados-membros e os Municípios, que são entes autônomos. A própria Constituição Federal define as atribuições do Estado Federal e dos Estados-membros, concedendo competências exclusivas ou privativas, que não podem ser exercidas pelos demais entes federativos.

Assim, tem-se, no artigo 21 da Carta Magna, as atribuições conferidas à União Federal; no parágrafo $1^{\circ}$ do artigo 25, as competências dos Estados; e, no artigo 30, as competências dos Municípios.

Há, ainda, competências concorrentes, que, quando exercidas por um dos entes da Federação, não podem ser exercidas pelos demais. Na Constituição Federal, a competência concorrente abrange o âmbito legislativo, sendo que, nos termos do artigo 24, cabe à União legislar sobre normas gerais, remanescendo aos Estados a possibilidade de exercer sua competência no que se refere à adaptação das normas gerais às especificidades de seu território. Regis Fernandes de Oliveira exemplifica essa possibilidade com o caso da legislação sobre direito tributário, financeiro, penitenciário, econômico, urbanístico, orçamentário, etc. $^{237}$

Por fim, existem as competências comuns, estabelecidas no artigo 23 do Texto Constitucional, que podem ser exercidas por dois entes federados, concomitantemente. Incluem-se aqui a educação, saúde, meio ambiente, cultura e patrimônio.

A repartição de competências é uma das formas de garantir autonomia aos entes federativos, característica básica da uma Federação.

Mas é importante destacar que, da mesma forma que não há um modelo rígido de Federação, que é moldado por cada Estado às suas necessidades e pretensões específicas, a questão da "autonomia" não pode se pregada de forma a designar um dogma para todos os sistemas: "Deve, em verdade, constituir o grau, maior ou menor, de independência que a

237 OLIVEIRA, Regis Fernandes de. Curso de Direito Tributário. São Paulo: Revista dos Tribunais, 2006, p. 29. 
Unidade, o Estado, atribui aos entes. E tal independência assume várias competências, que compreendem alguns poderes." 238

Entretanto, a possibilidade de auto-organização e a atribuição de competência legislativa não são suficientes para que não haja hierarquia entre os entes federados. Para que se tenha um federalismo adequado, é imprescindível que todos os entes da Federação possuam autonomia financeira. ${ }^{239}$ Não há autonomia política ou administrativa sem a autonomia financeira. ${ }^{240}$

A Constituição Federal de 1988, além da repartição de competências legislativas acima descrita, optou por discriminar detalhadamente as competências tributárias da União Federal, dos Estados e Municípios.

Nesse sentido, Sacha Calmon Navarro Coêlho afirma:

A característica fundamental do federalismo é a autonomia do Estadomembro, que pode ser mais ou menos ampla, dependendo do país de que se esteja a cuidar. No âmbito tributário, a sustentar a autonomia política e administrativa do Estado-Membro e do Município - que no Brasil, como vimos, tem dignidade constitucional - impõe-se a preservação da autonomia financeira dos entes locais, sem a qual aqueloutras não existirão. Esta autonomia resguarda-se mediante a preservação da competência tributária das pessoas políticas que convivem na Federação e, também, pela eqüidosa discriminação constitucional das fontes de receita tributária, daí advindo a importância do tema referente à repartição de competências no Estado Federal, assunto inexistente, ou pouco relevante, nos Estados unitários (Regiões e Comunas). ${ }^{241}$

Assim, é essencial que seja analisada a adoção da discriminação rígida de competências tributárias pela Constituição Federal, o que será adiante tratado.

238 ELALI, André. O Federalismo Fiscal Brasileiro e o Sistema Tributário Nacional. São Paulo: MP Editora, 2005, p. 32.

239 REIS, Elcio Fonseca. Federalismo Fiscal: competência concorrente e normas gerais de direito tributário. Belo Horizonte: Mandamentos, 2000, p. 42.

240 DI PIETRO, Juliano. Repartição das Receitas Tributárias: A repartição do produto da arrecadação. As transferências intergovernamentais. In: CONTI, José Mauricio (Org.). Federalismo Fiscal. Barueri, SP: Manole, 2004, p. 69.

241 COÊLHO, Sacha Calmon Navarro. Curso de direito tributário brasileiro. 2. ed. Rio de Janeiro: Forense, 1999, p. 63. 
Nas palavras de Roque Antonio Carrazza, "competência tributária é a aptidão para criar, in abstracto, tributos" ${ }^{242}$. É a aptidão conferida pela Constituição Federal para as pessoas jurídicas de direito público interno - entes da Federação - instituírem, por meio de leis, tributos.

Conforme exposto acima, a Constituição Federal adotou uma discriminação detalhada e rígida de competências tributárias. Assim, a Carta Magna repartiu, de forma minudente e detalhada, as competências impositivas dos entes federativos, definindo o espectro de atuação legiferante em matéria tributária de cada um deles. ${ }^{243}$

O capítulo da Constituição Federal destinado ao Sistema Tributário Nacional iniciase no artigo 145, que dispõe que a União Federal, os Estados, o Distrito Federal e os Municípios poderão instituir impostos, taxas e contribuição de melhoria.

Com relação aos impostos, os artigos 153, 155 e 156 arrolam os impostos de cada ente tributante, a saber:

- União Federal: importação de produtos estrangeiros; exportação, para o exterior, de produtos nacionais ou nacionalizados; renda e proventos de qualquer natureza; produtos industrializados; operações de crédito, câmbio e seguro, ou relativas a títulos ou valores mobiliários; propriedade territorial rural, grandes fortunas; tratando ainda o artigo 154, I da competência residual e o inciso II de regra excepcional, em caso de guerra externa ou sua iminência, quando a União pode instituir impostos; ainda que não compreendidos em sua competência;

- Estados e Distrito Federal: transmissão causa mortis e doação, de quaisquer bens ou direitos; operações relativas à circulação de mercadorias e sobre prestações de serviços de transporte interestadual e intermunicipal e de comunicação, ainda

242 CARRAZZA, Roque Antonio. Curso de Direito Constitucional Tributário. 19. ed., rev. e ampl. até a EC 39/2002. São Paulo: Malheiros, 2003, p. 437.

243 BARRETO, Paulo Ayres. Contribuições: regime jurídico, destinação e controle. São Paulo: Noeses, 2006, p. 30. 
que as operações e as prestações se iniciem no exterior; e propriedade de veículos automotores;

- Municípios e Distrito Federal: propriedade predial e territorial urbana; transmissão inter vivos, a qualquer título, por ato oneroso, de bens imóveis, por natureza ou acessão física, e de direitos reais sobre imóveis, exceto os de garantia, bem como cessão de direitos a sua aquisição; e serviços de qualquer natureza, não compreendidos no art. 155, II, definidos em lei complementar.

As taxas e contribuições de melhoria, de acordo com o artigo 145 da Constituição Federal, são de competência de todos os entes tributantes, devendo-se lembrar que a competência tributária decorre da competência material para a prestação estatal que serve de fato gerador. Assim, tratando-se de tributos vinculados à atuação estatal, apenas o ente que tem competência para a prestação estatal poderá exigir o tributo correspondente. Tal sistemática evita a cumulação de tributos. ${ }^{244}$

Ademais, nos termos do artigo 149 da Carta Magna, é de competência exclusiva da União Federal a instituição de contribuições sociais, de intervenção no Domínio Econômico e de interesse das categorias profissionais ou econômicas, excetuada a competência dos Estados, Distrito Federal e Municípios, para instituírem contribuições, cobradas de seus servidores, para o custeio, em benefício destes, de sistemas de previdência e assistência social.

A Emenda Constitucional $\mathrm{n}^{\circ}$ 39/2002 acrescentou o artigo 149-A ao Texto Constitucional, outorgando nova competência aos Municípios e Distrito Federal para a instituição de contribuição para o custeio do serviço de iluminação pública.

Por último, os empréstimos compulsórios são de competência exclusiva da União Federal, conforme previsto no artigo 148 da Constituição Federal.

244 SCHOUERI, Luis Eduardo. Normas Tributárias Indutoras e Intervenção Econômica. Rio de Janeiro: Forense, 2005, p. 343. 
Afirma-se que a rigidez do sistema constitucional tributário brasileiro decorreu da preocupação do constituinte em assegurar a autonomia dos entes federativos.

A intenção seria a de manter o equilíbrio na coexistência das diferentes entidades federativas, sem a intervenção de uma delas nas demais.

Geraldo Ataliba enfatiza que, ao contrário de outros sistemas federados, por exemplo, o norte-americano, a matéria tributária é exaustivamente tratada na Constituição Federal, limitando a atuação do legislador ordinário, que não tem competência para inovar o que já está expressamente traçado constitucionalmente. ${ }^{245}$

Ou seja, o sistema federado brasileiro, para se manter harmônico, fixou os contornos de atuação impositiva de cada entidade federativa, sob pena de não poder garantir a efetiva autonomia dos entes que o constituem. ${ }^{246}$

Ocorre, entretanto, que a discriminação de competências tributárias não é requisito de um sistema federal. Veja-se o caso norte-americano, que, apesar de se tratar de uma Federação, não possui uma discriminação detalhada de competências tributárias, existindo, inclusive, a possibilidade de bitributação. Isso porque a independência financeira dos Entes Federados pode ser assegurada por outras formas, como repartição e transferência de receitas entre as entidades.

Conti esclarece que a repartição do produto de arrecadação permite ajustar a distribuição de recursos de modo a atenuar distorções e propiciar uma partilha mais adequada de receitas. É possível adotar mecanismos de (i) participação direta na arrecadação, com a aplicação de regras que dividem a receita de um tributo entre diversos

\footnotetext{
245 ATALIBA, Geraldo. Sistema Constitucional Tributário Brasileiro. São Paulo: Revista dos Tribunais, 1968, p. 27.

246 ELALI, André. O Federalismo Fiscal Brasileiro e o Sistema Tributário Nacional. São Paulo: MP Editora, 2005 , p. 46.
} 
entes federativos ou (ii) participação indireta na arrecadação, através da transferência de recursos de um ente a outro por meio de fundos ${ }^{247}$ :

Consegue-se, por meio destes mecanismos, melhorar a equação que visa alcançar um dos objetivos almejados pelas técnicas de federalismo fiscal, que é a autonomia financeira dos entes federativos, com equidade e eficiência na partilha dos recursos, corrigindo-se os desequilíbrios verticais e horizontais existentes na Federação e buscando aproximar-se de um ideal de justiça fiscal. ${ }^{248}$

Fernando Rezende destaca os casos do Canadá e Alemanha, também Estados Federados, que optaram, para garantir a autonomia financeira de seus entes, por outros sistemas que não a distribuição detalhada de competências. ${ }^{249}$

No Canadá, o imposto de renda é controlado pelo governo federal, mas garante-se às províncias a possibilidade de participação da arrecadação mediante a aplicação de alíquotas próprias. A redução da alíquota federal permite o aumento das alíquotas das províncias, com o objetivo de reduzir desequilíbrios verticais quando necessário. ${ }^{250}$

Ademais, o país adota dois regimes independentes, financiados com recursos do orçamento federal com o objetivo de minimizar as disparidades das províncias. O sistema de equalização, baseado em estimativas de receita potencial para cada imposto, visa trazer províncias com baixa capacidade de gasto para a média nacional, a fim de que todas as províncias disponham de um orçamento per capita pelo menos igual à média nacional. Também há um regime destinado às áreas da saúde e educação. ${ }^{251}$

Na Alemanha, há um compartilhamento dos principais impostos, inclusive daqueles exigidos localmente sobre as atividades econômicas. A receita do IVA e do imposto de renda possui legislação centralizada, mas é repartida entre os três níveis de governo. Sua

247 CONTI, José Mauricio. Federalismo Fiscal e Reforma Tributária: Utopia ou Realidade? In: SCHOUERI, Luis Eduardo (Org.). Direito Tributário. Homenagem a Paulo de Barros Carvalho. v. 1. São Paulo: Quartier Latin, 2008, p. 909.

248 Ibid., loc. cit.

249 SILVA, Fernando Antonio Rezende da. A reforma tributária e a federação. Rio de Janeiro: FGV, 2009, p. 50 .

250 Ibid., p. 51.

251 Ibid., loc. cit. 
administração é de competência dos Estados, que atuam por meio de sua representação no Bunderast para influenciar nas normas legais e na partilha da arrecadação. ${ }^{252}$

A repartição da receita do imposto de renda é definida na Constituição, mas a do IVA é definida por lei ordinária, a fim de permitir mudanças necessárias à manutenção do equilíbrio vertical. ${ }^{253}$

O critério do sistema de equalização alemão é a capacidade de gasto per capita, simplificado pela adoção da redistribuição integral da receita arrecadada. O sistema de equalização possui três etapas: A primeira consiste na repartição da cota estadual do IVA que é distribuída, em parte ( $75 \%$ ), por critério per capita, sendo que os outros $25 \%$ são destinados aos estados mais pobres; na segunda, há trocas horizontais entre os Estados, caso em que os Estados com receita per capita acima da média nacional cedem recursos para os Estados com receita abaixo dessa média; e, por último, de acordo com os resultados obtidos nas etapas anteriores, o governo federal utiliza recursos de sua cota no IVA para transferências complementares, a fim de trazer a capacidade de gasto de todos os Estados para $99,5 \%$ da média nacional. ${ }^{254}$

Ou seja, a autonomia financeira é requisito indispensável para que se tenha uma Federação. Mas há diversas formas de obter referida autonomia, cabendo a cada Estado garanti-la no modelo que julgar mais adequado às suas expectativas.

O menor ou maior grau de autonomia dos entes subnacionais está intrinsecamente relacionado ao contexto histórico de cada país, que influencia na opção de concentração de competências ora no governo central, ora nos governos descentralizados. ${ }^{255}$

O Brasil optou por fazê-lo preponderantemente pela repartição rígida de competências, mas também adotou a repartição de receitas. No artigo 159, I, $a$, da

252 SILVA, Fernando Antonio Rezende da. A reforma tributária e a federação. Rio de Janeiro: FGV, 2009, p. 50.

253 Ibid., p. 51.

254 Ibid., p. 51-52.

255 GAMA, Evandro Costa. A Reforma Tributária e a Autonomia Financeira das Entidades Subnacionais. In: CONTI, José Mauricio (Org.). Federalismo Fiscal. Barueri, SP: Manole, 2004, p. 139. 
Constituição Federal, há previsão do Fundo de Participação dos Estados e Distrito Federal, composto por $21,5 \%$ da arrecadação da União com o imposto de renda e com o imposto sobre produtos industrializados. A distribuição desses valores aos Estados e Distrito Federal é fixada de acordo com fórmula que considera a região em que o Estado se situa, a superfície territorial, renda per capita e a população. ${ }^{256}$

Por sua vez, a alínea $b$ do mesmo artigo constitucional estabelece o Fundo de Participação dos Municípios, que é composto por 22,5\% da arrecadação dos mesmos tributos federais acima citados. São critérios para a repartição dos recursos o fato de o Município ser Capital de Estado, a renda per capita e a população. Ademais, a Emenda Constitucional $n^{\circ} 55 / 2007$, majorou a composição de receitas do fundo, com a inclusão de $1 \%$ dos impostos em questão, IR e IPI, parte esta distribuída aos Municípios no primeiro decêndio do mês de dezembro de cada ano. ${ }^{257}$

José Mauricio Conti cita ainda ( $i$ ) os Fundos de Financiamento do Norte, Nordeste e Centro-Oeste, compostos por 3\% da arrecadação do IR e IPI e distribuídos, regra geral, por meio de transferências intergovernamentais voluntárias e condicionadas, permitindo a alocação eficaz de recursos de acordo com as variações momentâneas das necessidades específicas de cada região, (ii) o Fundo para a Manutenção e Desenvolvimento da Educação Básica - FUNDEB ${ }^{258}$, cujas fontes de receitas decorrem de $20 \%$ dos recursos de impostos estaduais (ITCMD, ICMS e IPVA), de recursos municipais oriundos das transferências intergovernamentais recebidas pela arrecadação do ITR, IPVA e ICMS e dos Fundos de Participação dos Estados, Distrito Federal e dos Municípios e (iii) o fundo de Combate e Erradicação da Pobreza - FCEP ${ }^{259}$, formado por parte do produto de arrecadação da extinta CPMF, do IPI e de outras fontes. ${ }^{260}$

${ }^{256}$ CONTI, José Mauricio. Federalismo Fiscal e Reforma Tributária: Utopia ou Realidade? In: SCHOUERI, Luis Eduardo (Org.). Direito Tributário. Homenagem a Paulo de Barros Carvalho. v. 1. São Paulo: Quartier Latin, 2008, p. 910.

257 Op. cit., loc. cit.

258 Artigo 60 do ADCT

259 Artigos 79 e 80 do ADCT.

${ }^{260}$ CONTI, op. cit., loc. cit. 
Destaque-se, inclusive, que a repartição rígida de rendas foi a causa última e decisiva da criação da figura jurídica e política do Estado Federal.

Nesse sentido, Luis Eduardo Schoueri, citando Klaus Tipke, afirma que a discriminação de competências, com a proibição de instituição de impostos semelhantes, tem como objetivo evitar que mais de um ente federado sugue recursos de uma mesma manifestação da capacidade contributiva. E, mais importante que isso, a adoção dessa repartição rígida tem como objetivo proteger o contribuinte, evitar que haja um exagero de tributação. $^{261}$

Nessa linha, analisando o nosso sistema, Geraldo Ataliba reconhece que a preocupação era de evitar uma bitributação, tendo a adoção da rigidez do sistema tributário não apenas evitado tal efeito, mas garantindo também a autonomia financeira dos entes federativos:

As finalidades da rigidez da discriminação de rendas são: obviar a bitributação jurídica - o que se conseguiu amplamente - assegurar efetivamente a autonomia financeira das pessoas políticas e evitar conflitos de competência em matéria tributária.

$[\ldots]$

$\mathrm{Na}$ perseguição do intuito de obviar a bitributação - mediante a caracterização da inconstitucionalidade por invasão de competência - foi que se engendrou o sistema rígido, circunscritor de cada competência tributária como consequência natural e lógica, alcançou-se a rigidez do próprio sistema tributário constitucional. Assim, o exercício dessa faculdade, por qualquer das entidades políticas é - desde o plano legislativo - hirta e inflexivelmente ordenado, circunscrito, limitado e restrito. Pode-se dizer que o legislador constituinte atirou no que viu e acertou tanto no que viu quanto no que não viu. Criou um sistema completo, fechado e harmônico, que limita e ordena estritamente, não só cada poder tributante como - consequência lógica - toda a atividade tributária globalmente considerada. ${ }^{262}$

261 SCHOUERI, Luis Eduardo. Discriminação de Competências e Competência Residual. In: ZILVETI, Fernando Aurelio. Direito Tributário: estudos em homenagem a Brandão Machado. São Paulo: Dialética, 1998, p. 106.

262 ATALIBA, Geraldo. Sistema Constitucional Tributário Brasileiro. São Paulo: Revista dos Tribunais, 1968, p. 27. 
Nessa linha, Aliomar Baleeiro afirma que "aliás, é mais exato dizer-se que foi a discriminação de rendas a causa última e decisiva da criação da figura jurídica e política do Estado Federal, como novidade do fim do século XVIII". 263

Assim, pode-se afirmar que a discriminação rígida de competências tem como objetivo principal evitar a tributação excessiva e proteger os cidadãos, embora tenha alcançado também a garantia da autonomia financeira dos Estados da Federação:

Circunscrita a competência tributária e partilhada as materialidades sobre as quais se poderia instituir tributos por cada ente federativo, evidenciado restou que o constituinte tanto se esmerou em evitar a bitributação, como também predefiniu o equilíbrio econômico da Federação. ${ }^{264}$

Posto isto e demonstrado que a repartição de competências tributárias não é a única forma de obter autonomia financeira como alternativa para a manutenção de uma estrutura federativa, havendo ainda a preocupação em proteger o contribuinte de uma tributação excessiva, passaremos a tratar dos problemas gerados pela imputação da tributação sobre o consumo no âmbito estadual, em face da estrutura federativa e da possibilidade de reforma constitucional que atinja a discriminação de competências tributárias atualmente vigente, em face do disposto no artigo 60, parágrafo $4^{\circ}$ da Constituição Federal.

\subsection{Guerra Fiscal entre os Estados da Federação Relativamente ao ICMS}

Conforme exposto acima, para que os Estados tenham autonomia financeira, a Constituição Federal outorgou-lhes competência para instituir o ICMS.

263 BALEEIRO, Aliomar. Uma Introdução à Ciência das Finanças. 16. ed. rev. e atualizada por Dejalma de Campos. Rio de Janeiro: Forense, 2006, p. 234.

264 EMERENCIANO, Adelmo da Silva. Modificação na Competência Tributária por Emenda Constitucional. A Contribuição para Custeio do Serviço de Iluminação Pública - Emenda Constitucional 39/2002. In: SANTI, Eurico Marcos Diniz de (Coord.). Curso de Especialização em Direito Tributário: Estudos Analíticos em Homenagem a Paulo de Barros Carvalho - Rio de Janeiro: Forense, 2007, p. 904. 
No entanto, a fim de preservar a estrutura federativa, limitou a concessão de incentivos fiscais, condicionando-a à deliberação prévia e conjunta dos Estados e Distrito Federal, para aprovação por convênio.

Nesse contexto, o artigo 155, parágrafo $2^{\circ}$, XII, g, da Constituição Federal dispõe que cabe à lei complementar "regular a forma como, mediante deliberação dos Estados e do Distrito Federal, isenções, incentivos e benefícios fiscais serão concedidos e revogados".

Por sua vez, a Lei Complementar nº 24/75 determina que:

Art. $1^{\circ}$ - As isenções do imposto sobre operações relativas à circulação de mercadorias serão concedidas ou revogadas nos termos de convênios celebrados e ratificados pelos Estados e pelo Distrito Federal, segundo esta Lei.

Parágrafo único - O disposto neste artigo também se aplica:

I - à redução da base de cálculo;

II - à devolução total ou parcial, direta ou indireta, condicionada ou não, do tributo, ao contribuinte, a responsável ou a terceiros;

III - à concessão de créditos presumidos;

IV - à quaisquer outros incentivos ou favores fiscais ou financeiro-fiscais, concedidos com base no Imposto de Circulação de Mercadorias, dos quais resulte redução ou eliminação, direta ou indireta, do respectivo ônus;

V - às prorrogações e às extensões das isenções vigentes nesta data.

Art. $2^{\circ}$ - Os convênios a que alude o art. $1^{\circ}$, serão celebrados em reuniões para as quais tenham sido convocados representantes de todos os Estados e do Distrito Federal, sob a presidência de representantes do Governo federal.

Ocorre que, sob o argumento de promover o desenvolvimento econômico de seus territórios, os Estados ignoram a condição imposta constitucionalmente, concedendo unilateralmente incentivos fiscais de ICMS de diversas naturezas, para atrair investimentos empresariais, ignorando, dessa forma, os limites previstos na Lei Complementar $n^{\circ}$ 24/75. 
Neste cenário, os Estados acabam competindo entre si, concedendo cada vez mais incentivos fiscais, na tentativa de tornar o seu território o mais atrativo possível para os investimentos. São concedidos os mais diversos tipos de benefícios: isenções, reduções de base de cálculo, créditos presumidos, reduções de alíquotas, diferimentos, concessão de prazos para pagamento, financiamento do valor do imposto devido etc. Essa conduta configura o que se chama guerra fiscal.

Daniel Monteiro Peixoto esclarece que guerra fiscal "é expressão que representa metaforicamente o esforço competitivo entre as pessoas políticas para que a alocação de investimentos privados seja direcionada aos seus respectivos territórios". 265

Nessa linha, Gilberto Ayres Moreira afirma:

Entretanto, em que pese o método insculpido na Lei Maior limitar a competência exonerativa dos entes federados, estes, no intuito de trazer o desenvolvimento aos seus territórios, acabam por fazer tabula rasa da ordem constitucional, e passam unilateralmente a conceder incentivos fiscais de toda ordem em matéria de ICMS.

Esta é a chamada guerra fiscal $[\ldots]^{266}$

Em decorrência da concessão desenfreada de incentivos fiscais, que ignoram as limitações traçadas na Constituição Federal, observa-se o crescente número de ações por parte dos Estados que se sentem prejudicados perante o Supremo Tribunal Federal, que questionam a legitimidade dos benefícios e, ainda, a aplicação de sanções aos contribuintes adquirentes de mercadorias beneficiadas em operações interestaduais.

Abordaremos, a seguir, os efeitos das ações ajuizadas perante o Supremo Tribunal Federal e, ainda, a legitimidade das sanções impostas pelos Estados aos contribuintes.

265 PEIXOTO, Daniel Monteiro. Guerra Fiscal via ICMS: Controle dos Incentivos Fiscais e os Casos "FUNDAP" e "COMUNICADO CAT N. 36/2004". In: MARTINS, Ives Gandra da Silva; ELALI, André; PEIXOTO, Marcelo Magalhães. Incentivos Fiscais - Questões Pontuais nas Esferas Federal, Estadual e Municipal. São Paulo: MP Editora, 2007, p. 67.

266 MOREIRA, Gilberto Ayres. A “Guerra Fiscal” e os limites ao princípio da não-cumulatividade do ICMS. Revista de Direito Tributário, Rio de Janeiro: Malheiros, n. 85, 2002, p. 236. 


\subsubsection{O AJUIZAMENTO DE AÇÕES DECLARATÓRIAS DE INCONSTITUCIONALIDADE E SEUS EFEITOS}

Nos termos anteriormente mencionados, os incentivos fiscais de ICMS concedidos sem aprovação por convênio firmado entre os Estados afronta a regra constitucional prevista no artigo 155, parágrafo $2^{\circ}$, XII, “g”. Assim, o Estado que se sentir lesado pela concessão irregular de benefícios de ICMS, por outro Estado, tem a faculdade de ajuizar ação declaratória de inconstitucionalidade, com base no artigo 102, I, "a" e "f", do Diploma Constitucional, para que a norma jurídica ilegítima seja devidamente retirada do ordenamento jurídico.

Nesse sentido, destaque-se que o Supremo Tribunal Federal já firmou entendimento contrário à guerra fiscal, declarando inconstitucionais diversos incentivos concedidos unilateralmente pelos Estados, por ofensa ao artigo 155, parágrafo $2^{\circ}$, inciso II, "g", da Constituição Federal e à Lei Complementar no 24/75. Em junho de 2011, a Corte Suprema julgou 14 ações declaratórias inconstitucionais (2906, 2376, 3674, 3413, 4457, 3664, 3803, $2688,3794,4152,2352,702,1247$ e 2549 , reconhecendo, em todas, a irregularidade de incentivos concedidos sem aprovação pelo CONFAZ.

Há, inclusive, discussão sobre súmula vinculante dispondo sobe o assunto, proposta pelo Min. Gilmar Mendes. ${ }^{267}$

${ }^{267}$ PROPOSTA DE SÚMULA VINCULANTE No 69

PROPTE.(S) : SUPREMO TRIBUNAL FEDERAL EDITAL DE PROPOSTA DE SÚMULA VINCULANTE

Prazo: 20 (vinte) dias.

Proposta de Verbete: Qualquer isenção, incentivo, redução de alíquota ou de base de cálculo, crédito presumido, dispensa de pagamento ou outro benefício fiscal relativo ao ICMS, concedido sem prévia aprovação em convênio celebrado no âmbito do CONFAZ, é inconstitucional.

Interessados: todos que este edital virem ou dele conhecimento tiverem.

Finalidade: conforme Emenda Regimental n $\mathrm{n}^{\circ}$ 46/STF, publicada em 8 de julho de 2011 no Diário da Justiça Eletrônico, e nos termos do $\S 2^{\circ}$ do artigo $3^{\circ}$ da Lei $n^{\circ} 11.417 / 2006$, ficam cientes os interessados para, querendo, manifestarem-se no prazo de 5 (cinco) dias, depois de findo o prazo de 20 (vinte) dias acima fixado, que passa a fluir a partir da disponibilização deste edital no Diário da Justiça Eletrônico, na forma da legislação processual vigente.

Secretaria do Supremo Tribunal Federal, em 12 de abril de 2012. (http://www.stf.jus.br/portal/processo/verProcessoAndamento.asp?incidente=4222438 - PSV 69 PROPOSTA DE SÚMULA VINCULANTE) 
Apreciada pela Corte Suprema e reconhecida a ilegitimidade do benefício fiscal, a norma será retirada do ordenamento jurídico, a princípio, com efeitos retroativos. Nesse sentido, Julio Maria de Oliveira e Carolina Romanini Miguel afirmam:

\begin{abstract}
Uma vez declarada a inconstitucionalidade da norma estadual ou distrital, a decisão terá efeito retroativo (ex tunc) e para todos (erga omnes), desfazendo, desde sua origem, $\mathrm{o}$ ato declarado inconstitucional, juntamente com todas as consequências dele derivadas, uma vez que estes atos são nulos e, portanto, destituídos de eficácia jurídica, alcançando a declaração de inconstitucionalidade, inclusive os atos pretéritos com base nela praticados. ${ }^{268}$
\end{abstract}

Porém, na prática, é questionável a eficácia das decisões do Supremo Tribunal Federal.

Isso porque os julgamentos tardam a ocorrer, enquanto a legislação questionada está vigente e surtindo efeitos. Ademais, para burlar os efeitos da decisão do Supremo Tribunal Federal, os Estados já editam os benefícios por período limitado ou revogam a legislação questionada antes que seja realizado o julgamento de sua constitucionalidade, resultando na perda de objeto da demanda. ${ }^{269}$

Também não há como obrigar o Estado a exercer a competência tributária e exigir dos contribuintes o pagamento do ICMS que não foi recolhido nas operações pretéritas.

Há, ainda, a possibilidade de os Estados editarem leis concedendo anistia/remissão das dívidas, para que os contribuintes que usufruíram dos benefícios não sejam prejudicados, tendo que recolher o ICMS incidente nas operações pretéritas, acrescidos de juros e multa de mora.

268 OLIVEIRA, Julio Maria de; MIGUEL, Carolina Romanini. Guerra Fiscal ou Terrorismo Estatal. In: SANTI, Eurico Marcos Diniz de; ZILVETI, Fernando Aurelio (Coords.). Tributação Empresarial. São Paulo: Saraiva, 2009, p. 140.

269 BATISTA, Luiz Rogério Sawaya. Créditos do ICMS na Guerra Fiscal. São Paulo: Quartier Latin, 2012, p. 100. 
Também deve ser observada a possibilidade de o Supremo Tribunal Federal modular os efeitos de sua decisão, por maioria de $2 / 3$ de seus membros, para que a decisão tenha efeitos ex nunc.

Das quatorze ações declaratórias de inconstitucionalidade acima mencionadas, que foram julgadas em junho de 2011, há recursos em cinco casos justamente para discutir a modulação dos efeitos do acórdão (ADIs 3674, 3413, 3794, 4152, 3702 e 2549). No caso da ADI 3702, os Embargos de Declaração não foram apreciados, uma vez que apresentados intempestivamente. Já no que se refere ao benefício discutido na ADI 2549, a modulação dos efeitos da decisão foi realizada pelo próprio Confaz (Convênio 84/2011 ${ }^{270}$ ).

${ }^{270}$ CONVÊNIO ICMS 84, DE 30 DE SETEMBRO DE 2011

- Publicado no DOU de 05.10.11, pelo Despacho 179/11.

- Ratificação Nacional no DOU de 21.10.11, pelo Ato Declaratório 15/11.

Suspende e concede remissão do ICMS relativos aos créditos tributários decorrentes do tratamento tributário concedido nos termos da Lei $\mathrm{n}^{\circ}$ 2.483/1999, que estabelece o tratamento tributário para empreendimentos econômicos produtivos no âmbito do Programa de Promoção do Desenvolvimento Econômico Integrado e Sustentável do Distrito Federal - PRÓ-DF.

O Conselho Nacional de Política Fazendária - CONFAZ, na sua $143^{a}$ reunião ordinária, realizada em Manaus, AM, no dia 30 de setembro de 2011, tendo em vista o disposto na Lei Complementar ${ }^{\circ} 24$, de 7 de janeiro de 1975, resolve celebrar o seguinte

C O N V ÊNIO

Cláusula primeira. Fica suspensa a exigibilidade dos créditos tributários do ICMS provenientes da diferença entre os créditos apurados pelo regime normal de apuração e o tratamento tributário concedido em decorrência do art. $2^{\circ}$, inciso I, e seus $\S \S 2^{\circ}$ e $3^{\circ}$, art. $5^{\circ}$, incisos I, II e III e seu parágrafo único, inciso I do art. $6^{\circ}$ em sua integralidade, e $\S \S 1^{\circ}$ e $2^{\circ}$ do art. $7^{\circ}$ da Lei Distrital ${ }^{\circ} 2.483$, de 19 de novembro de 1999 , que estabelece o tratamento tributário para empreendimentos econômicos produtivos no âmbito do Programa de Promoção do Desenvolvimento Econômico Integrado e Sustentável do Distrito Federal PRÓ-DF, desconstituídos judicialmente por não atender o disposto no art. $155, \S 2^{\circ}$, XII, "g", da Constituição Federal, até 30 de setembro de 2011, de acordo com o seguinte cronograma:

I - até 31 de dezembro de 2013, para os créditos tributários decorrentes de fatos geradores ocorridos até 31 de dezembro de 2008;

II - até 31 de dezembro de 2014, para os créditos tributários decorrentes de fatos geradores ocorridos de $1^{\circ}$ de janeiro a 31 de dezembro de 2009 ;

III - até 31 de dezembro de 2015, para os créditos tributários decorrentes de fatos geradores ocorridos de $1^{\circ}$ de janeiro a 31 de dezembro de 2010 ;

IV - até 31 de dezembro de 2016, para os créditos tributários decorrentes de fatos geradores ocorridos de $1^{\circ}$ de janeiro a 30 de setembro de 2011.

Parágrafo único. Fica concedida, desde que atendido os requisitos da cláusula terceira deste convênio, remissão dos créditos tributários suspensos na forma do caput, nos termos finais de sua suspensão.

Cláusula segunda Fica suspensa a exigibilidade dos créditos tributários apropriados pelos contribuintes destinatários, localizados no Distrito Federal e nas demais unidades federadas, decorrentes de operações cuja exigibilidade dos créditos tributários dos remetentes esteja suspensa na forma da cláusula primeira.

$\S 1^{\circ}$ Será concedida remissão dos créditos tributários dos contribuintes destinatários nas mesmas datas em que ocorrerem as remissões previstas no cronograma da cláusula primeira.

$\S 2^{\circ}$ Não se suspendem nem se remitem os valores cobrados por meio de autos de infração das administrações tributárias das unidades federadas, exceto a do Distrito Federal, contra seus contribuintes. 
Nesse caso, o Estado de origem não precisará exigir o ICMS renunciado nas operações já realizadas, de forma a não prejudicar os contribuintes que usufruíram dos benefícios e que agiram de boa-fé e foram atraídos pelos benefícios, cumprindo todos os requisitos para gozá-los, muitas vezes transferindo seus estabelecimentos para Estados em que não atuavam, ali investindo e gerando empregos. ${ }^{271}$

Mesmo porque não é aceitável que, tendo observado os preceitos legais, a legislação vigente e válida, os contribuintes sejam posteriormente penalizados pelo Estado que expediu tais normas:

A administração pública e respectivos agentes administrativos devem atuar em conformidade com o princípio da moralidade administrativa, previsto no art. 37 da $\mathrm{CF}$, de forma a não contrariar o princípio da boa-fé dos contribuintes.

\section{$[\ldots]$}

Portanto, a modificação de entendimento jurídico mediante novas normas jurídicas e alterações jurisprudenciais consolidadas pelos tribunais administrativos e judiciais resulta na circunstância de se curvar ao fato de que a administração pública, de forma astuciosa, expressa em um primeiro momento normas que tenham por finalidade incentivar os contribuintes para que, em um segundo momento, aplicasse determinada sanção, resultando em desarmonia com a moralidade administrativa. ${ }^{272}$

Carrazza é categórico ao afirmar que o contribuinte de boa-fé não pode ser prejudicado no caso de benefícios que usufrui serem considerados inconstitucionais:

Cláusula terceira O Distrito Federal, nos termos deste convênio e a partir de sua celebração, acorda em não conceder ou prorrogar incentivos ou benefícios fiscais vinculados ao ICMS concedidos com base na norma referida na cláusula primeira, ressalvada a concessão ou prorrogação na forma prevista na Lei Complementar $\mathrm{n}^{\circ} 24$, de 7 de janeiro de 1975.

Cláusula quarta A aprovação do disposto neste convênio não implica reconhecimento unânime do direito à glosa de créditos decorrente de benefícios fiscais concedidos por outras unidades da Federação.

Cláusula quinta Este convênio entra em vigor na data da sua publicação, produzindo efeitos a partir da ratificação nacional.

271 BECATTINI, Stefania; CARDOSO, Bruno Oliveira. A Glosa de Créditos de Incentivos Fiscais de ICMS. Revista de Direito Tributário, São Paulo: Associação Paulista de Estudos Tributários, n. 5, mar. 2005, p. 155.

${ }^{272}$ MELO, Fábio Soares de. Incentivos Fiscais e Segurança Jurídica. In: MARTINS, Ives Gandra da Silva; ELALI, André; PEIXOTO, Marcelo Magalhães. Incentivos Fiscais - Questões Pontuais nas Esferas Federal, Estadual e Municipal. São Paulo: MP Editora, 2007, p. 142. 
E aqui voltamos a um dos problemas centrais deste estudo: como ficam as empresas contribuintes de ICMS que, para usufruírem de benefícios fiscais ou financeiros, agiram de acordo com o que estatuíam as leis locais, que supunham traduzir o melhor direito?

A nosso ver, tais empresas, em homenagem, se por mais não fosse, ao princípio da boa-fé, devem ter preservadas as situações que surgiram até a declaração da inconstitucionalidade dos aludidos benefícios.

As vantagens no campo do ICMS, obtidas enquanto a legislação estadual não for declarada inconstitucional, devem ser preservadas. Afinal, as empresas não podem ser punidas, justamente por haverem se norteado na bússola da legislação da própria entidade tributante.

Nunca é demais insistir que o Estado deve inspirar confiança nas pessoas e, portanto, não pode punir os que, munidos de boa-fé, agem em consonância com o que a lei estabelece. Ainda que esta lei venha a ser declarada inconstitucional. ${ }^{273}$

A impossibilidade de exigir o ICMS é ainda mais evidente no caso em que os benefícios são concedidos mediante o cumprimento de determinadas condições (geração de empregos, investimentos mínimos etc.) que geram ônus ao contribuinte:

Realmente, se os contribuintes de ICMS suportaram ônus ou despesas, preenchendo os requisitos legais, para gozaram da vantagem, nem mesmo uma decisão prolatada em ação direta de inconstitucionalidade poderá turbar-lhes o direito em tela.

É que, com o cumprimento da condição, o benefício fiscal ou financeiro passou a pertencer ao patrimônio dos contribuintes, pelo quê têm o direito adquirido de não perderem a vantagem usufruída. ${ }^{274}$

Por óbvio que, se ficarem comprovadas, respeitando-se o devido processo legal e a ampla defesa, a ausência de boa-fé do contribuinte ou irregularidades na utilização de benefícios, deverá o Estado exigir o recolhimento de eventuais diferenças de ICMS. ${ }^{275}$

José Eduardo Soares de Mello destaca também a possibilidade de os Estados concederem benefícios por meio de regimes especiais, e não mediante a edição de lei ou

273 CARRAZZA, Roque Antonio. ICMS. 15. ed., rev. e ampl. até a EC 67/2011, de acordo com a Lei Complementar 87/1996 com suas ulteriores modificações. São Paulo: Malheiros, 2011, p. 401.

274 Ibid., p. 404.

275 Ibid., p. 402. 
decreto, a fim de evitar o cabimento de propositura de ação direta de inconstitucionalidade. ${ }^{276}$

Por todos esses motivos os Estados, em vez de ajuizar a ação perante o Supremo Tribunal Federal, preferem aplicar sanções aos contribuintes adquirentes de mercadorias em operações interestaduais beneficiadas.

Ou seja, diante do âmbito limitado dos efeitos de uma decisão favorável em ação direta de inconstitucionalidade, que seria o instrumento adequado para os Estados questionarem incentivos concedidos irregularmente ${ }^{277}$, os entes federados optam por adotar medidas com efeitos mais imediatos e que prejudicam diretamente os contribuintes. Nesse sentido, veja-se a conclusão de Gilberto Ayres Moreira:

A Lei Principal autoriza as unidades federadas e as associações de classe a proporem ações diretas de inconstitucionalidade perante o STF visando a extirpar do ordenamento jurídico pátrio as normas jurídicas que ilegitimamente tenham por objeto a concessão de benefícios fiscais unilaterais.

No entanto, alguns Estados, objetivando afastar os efeitos da abusiva concessão unilateral destas vantagens, e veladamente procurando novas receitas tributárias, acabam por escolher um novo inimigo nesta guerra fiscal - qual seja, o contribuinte.

Ao invés de apontarem suas armas para as unidades federadas e as normas jurídicas que infringiram o Texto Supremo, dirigem sua munição contra os contribuintes que se encontram dentro de seus próprios territórios.

Estes entes tributantes preferem tomar medidas indiretas, como exigir dos contribuintes que adquiram mercadorias ou que tomaram serviços das empresas unilateralmente incentivadas $\mathrm{o}$ valor correspondente à vantagem obtida junto ao Estado de origem. ${ }^{278}$

${ }^{276}$ MELO, José Eduardo Soares de. O ICMS, os Benefícios Fiscais Concedidos unilateralmente por Certos Estados, as Medidas de Defesa Judicial e Extrajudicial Adotadas por outros Estados e Consequências para os Contribuintes. In: ROCHA, Valdir de Oliveira (Coord.). Grandes Questões Atuais do Direito Tributário, São Paulo: Dialetica, v. 9, p. 325-348, 2005, p. 336.

277 BATISTA, Luiz Rogério Sawaya. Créditos do ICMS na Guerra Fiscal. São Paulo: Quartier Latin, 2012, p. 164.

278 MOREIRA, Gilberto Ayres. A “Guerra Fiscal” e os limites ao princípio da não-cumulatividade do ICMS. Revista de Direito Tributário, Rio de Janeiro: Malheiros, n. 85, 2002, p. 236-237. 
Dessa forma, passaremos a analisar a constitucionalidade das medidas sancionatórias impostas pelos Estados.

\subsubsection{AS FORMAS DE CONCESSÃo DE BENEFÍCIOS FISCAIS: CRÉDITOS PRESUMIDOS E BENEFÍCIOS FINANCEIROS}

Antes de abordar a constitucionalidade das sanções aplicadas pelos Estados, com base na Lei Complementar $n^{\circ} 24 / 75$, é importante definir a natureza dos benefícios que são abrangidos pelo artigo 155 da Constituição Federal e regulamentados pela mencionada lei complementar.

Já esclarecemos que a Constituição Federal atribuiu aos Estados a deliberação conjunta sobre a concessão de incentivos físcais, determinando que cabe à lei complementar "regular a forma como, mediante deliberação dos Estados e do Distrito Federal, isenções, incentivos e benefícios fiscais serão concedidos e revogados".

O Texto Constitucional menciona, portanto, tão-somente incentivos fiscais, nada afirmando sobre benefícios financeiros ou concessão de créditos presumidos.

Ao regulamentar a Carta Magna, a Lei Complementar n ${ }^{\circ}$ 24/75, contudo, aborda a necessidade e procedimento para a concessão de incentivos, incluindo entre eles, além daqueles de natureza fiscais, também os que possuem natureza financeira, conforme se verifica em seu artigo $1^{\circ}$, que cita expressamente redução da base de cálculo, devolução total ou parcial, direta ou indireta, condicionada ou não, do tributo, ao contribuinte, a responsável ou a terceiros, concessão de créditos presumidos e quaisquer outros incentivos ou favores fiscais ou financeiro-fiscais, concedidos com base no Imposto de Circulação de Mercadorias, dos quais resulte redução ou eliminação, direta ou indireta, do ônus do tributo.

Ora, muito embora a Lei Complementar $n^{\circ} 24 / 75$ tenha sido recepcionada pela Constituição Federal de 1988, fato é que se o novel texto constitucional nada dispôs sobre a necessidade de lei complementar regulamentar a concessão de incentivos financeiros, não 
se pode exigir que a concessão de referidos benefícios seja aprovada por convênio, conforme determina a mencionada lei complementar.

Veja-se que a Constituição Federal de 1967 e a Emenda Constitucional no 1 de 1969 mencionavam apenas isenções. Assim, se a Constituição Federal de 1988 ampliou a redação que havia na Constituição anterior para incluir "incentivos e benefícios fiscais", mas nada dispôs sobre os benefícios financeiros, significa que não havia interesse na sua regulamentação por lei complementar.

Nesse contexto, não se pode admitir a aplicação do disposto na Lei Complementar $n^{\circ} 24 / 75$ aos benefícios financeiros. Julio Maria de Oliveira e Carolina Romanini Miguel esclarecem:

Diante disso, é possível entender que o legislador ampliou o sentido conferido às expressões isenções, incentivos e benefícios fiscais trazidas pela alínea g, do inciso XII, \$2 do seu artigo 155, da Constituição Federal, pois, de acordo com este dispositivo constitucional, os incentivos e favores financeiros podem ser concedidos segundo critérios de conveniência e oportunidade (discricionariedade), dependendo de deliberação dos Estados e Distrito Federal apenas os benefícios fiscais.

Nessa medida, a recepção do art. 1 da Lei Complementar n. 24/75 pela Constituição Federal de 1988 é passível de questionamento, dado o fato de esta, em momento algum, outorgar competência à Lei Complementar para dispor sobre benefícios de natureza financeira. ${ }^{279}$

Veja-se, ademais, entendimento manifestado pelo Supremo Tribunal Federal:

\author{
ADI 2056 / MS - MATO GROSSO DO SUL \\ AÇÃO DIRETA DE INCONSTITUCIONALIDADE \\ Relator(a): Min. GILMAR MENDES \\ Julgamento: 30/05/2007 Órgão Julgador: Tribunal Pleno
}

${ }^{279}$ OLIVEIRA, Julio Maria de; MIGUEL, Carolina Romanini. Guerra Fiscal ou Terrorismo Estatal. In: SANTI, Eurico Marcos Diniz de; ZILVETI, Fernando Aurelio (Coords.). Tributação Empresarial. São Paulo: Saraiva, 2009, p. 114. 
EMENTA: Ação Direta de Inconstitucionalidade. Artigos $9^{\circ}$ a 11 e 22 da Lei n. 1.963, de 1999, do Estado do Mato Grosso do Sul.

2. Criação do Fundo de Desenvolvimento do Sistema Rodoviário do Estado de Mato Grosso do Sul - FUNDERSUL. Diferimento do ICMS em operações internas com produtos agropecuários.

3. A contribuição criada pela lei estadual não possui natureza tributária, pois está despida do elemento essencial da compulsoriedade. Assim, não se submete aos limites constitucionais ao poder de tributar.

4. O diferimento, pelo qual se transfere o momento do recolhimento do tributo cujo fato gerador já ocorreu, não pode ser confundido com a isenção ou com a imunidade e, dessa forma, pode ser disciplinado por lei estadual sem a prévia celebração de convênio.

5. Precedentes.

6. Ação que se julga improcedente. ${ }^{280}$

Entre os benefícios financeiros que, em nossa opinião, não se sujeitam aos ditames da Lei Complementar, podemos citar: mecanismos financeiros à redução do valor a ser pago a título do imposto em virtude de um recolhimento presumido, da devolução posterior do tributo pago, concessão de condições facilitadas para pagamento do tributo, subvenções, financiamentos etc.

Ademais, considerando que os entes da Federação Brasileira possuem autonomia política e financeira, há de concluir que podem dispor sobre seus recursos, devendo observar apenas as limitações impostas por normas constitucionais, únicas regras que podem limitar essa autonomia. ${ }^{281}$

Dessa forma, concluímos que é inconstitucional a aplicação da regulamentação da Lei Complementar $n^{\circ} 24 / 75$ à concessão de benefícios financeiros. Esses benefícios se

${ }^{280}$ BRASIL. Supremo Tribunal Federal. Ação Direta de Inconstitucionalidade $n^{o}$ 2.056/MS. Relator: Ministro Gilmar Mendes. Julgamento: 30 maio 2007. Órgão Julgador: Tribunal Pleno. Publicação: DJ 113, 14 jun. 2007.

281 OLIVEIRA, Julio Maria de; MIGUEL, Carolina Romanini. Guerra Fiscal ou Terrorismo Estatal. In: SANTI, Eurico Marcos Diniz de; ZILVETI, Fernando Aurelio (Coords.). Tributação Empresarial. São Paulo: Saraiva, 2009, p. 115. 
sujeitam apenas aos limites traçados pela Lei Complementar $n^{\circ}$ 101/2000 (Lei de Responsabilidade Fiscal). ${ }^{282}$

\subsubsection{A AplicaÇÃo CUMUlativa da AnUlação do CRÉdito E A EXIGIBILIDADE DO ICMS}

A Lei Complementar n 24/75, ao tratar das sanções no caso de concessão irregular de incentivos fiscais, dispõe:

Art. $8^{\circ}$ - A inobservância dos dispositivos desta Lei acarretará, cumulativamente:

I - a nulidade do ato e a ineficácia do crédito fiscal atribuído ao estabelecimento recebedor da mercadoria;

Il - a exigibilidade do imposto não pago ou devolvido e a ineficácia da lei ou ato que conceda remissão do débito correspondente.

Parágrafo único - As sanções previstas neste artigo poder-se-ão acrescer a presunção de irregularidade das contas correspondentes ao exercício, a juízo do Tribunal de Contas da União, e a suspensão do pagamento das quotas referentes ao Fundo de Participação, ao Fundo Especial e aos impostos referidos nos itens VIII e IX do art. 21 da Constituição federal.

Tal dispositivo, entretanto, está eivado de diversas inconstitucionalidades, o que leva à conclusão de que a conduta dos Estados que têm aplicado cumulativamente, em operações interestaduais, a glosa de créditos aos destinatários de operações beneficiadas por incentivos irregulares e a exigência do ICMS que deixou de ser recolhido pelo remetente no Estado de origem não têm amparo constitucional.

Conforme mencionado anteriormente, se o Estado se julga prejudicado em decorrência da concessão indevida de incentivos fiscais por outro Estado, o instrumento adequado para insurgir contra essa conduta é o ajuizamento de ação declaratória de inconstitucionalidade.

282 OLIVEIRA, Julio Maria de; MIGUEL, Carolina Romanini. Guerra Fiscal ou Terrorismo Estatal. In: SANTI, Eurico Marcos Diniz de; ZILVETI, Fernando Aurelio (Coords.). Tributação Empresarial. São Paulo: Saraiva, 2009, p. 115. 
Nesse sentido, em sede de pedido liminar, a Min. Ellen Gracie, do Supremo Tribunal Federal, reconheceu que a via adequada para questionar a matéria é a discussão perante a Corte Suprema, por meio de ação direta de inconstitucionalidade contra o Estado concedente do incentivo fiscal e não a realização de glosa do crédito tomado pelo adquirente da mercadoria, conforme se verifica na decisão abaixo transcrita:

\section{Decisão}

1. Trata-se de pedido de liminar em Ação Cautelar ajuizada para agregar efeito suspensivo a Recurso Extraordinário interposto pela ora Requerente nos autos dos Embargos à Execução Fiscal no 0079041435417. Tal recurso, interposto contra o acórdão proferido pelo Tribunal de Justiça de Minas Gerais, foi recebido, mas ainda não subiu a esta Corte.

2. A questão de fundo diz respeito a débitos da Requerente junto à Fazenda Estadual em razão da glosa de créditos de ICMS apropriados em operação interestadual correspondentes ao valor de benefício fiscal supostamente inválido concedido pelo Estado de Goiás aos estabelecimentos lá situados. Dos $12 \%$ apropriados, o Estado de Minas Gerais glosou 2\%, porquanto o Estado de Goiás concede crédito em tal montante quando da remessa de mercadorias para outro Estado. Os créditos de ICMS glosados implicaram cobrança do tributo no Estado de destino, o que está em curso na Execução Fiscal embargada.

3. Entende, a ora Requerente, que não podem ser glosados seus créditos de ICMS, porquanto efetivamente incidiu a alíquota de $12 \%$, calculada e destacada na Nota Fiscal. O benefício fiscal supostamente inválido diz respeito a crédito concedido ao estabelecimento sediado em Goiás. Destaca que a glosa deu-se mediante invocação dos arts. 62, 68 e 71 do Regulamento do ICMS do Estado de Minas Gerais, bem como no Decreto 38.104/96 e da Resolução 3.166/01, mas que o acórdão que a chancelou viola diversos dispositivos constitucionais.

Ofenderia o art. 97 da Constituição Federal porque afirma a inconstitucionalidade do benefício fiscal concedido pelo Estado de Goiás sem observância do quórum qualificado exigido. O art. 102, I, a, por sua vez, restaria violado porque caberia ao Supremo Tribunal Federal tal reconhecimento. Implicaria contrariedade ao art. 150, I, porque, à época dos fatos, não havia qualquer dispositivo legal que respaldasse as previsões do Regulamento do ICMS e da Resolução. Destoaria do art. 155 , II, $\S 2^{\circ}$, I, da Constituição porque a sistemática da nãocumulatividade assegura o creditamento do tributo destacado na Nota. Por fim, estaria afrontando o inciso IV deste mesmo $\S 2^{\circ}$ porquanto cabe ao Senado a definição da alíquota interestadual, sendo que a orientação do Estado de Minas Gerais teria o efeito de reduzi-la.

[...] 
5. O pano de fundo da questão é a chamada "guerra fiscal", sendo certo que, apenas mediante previsão em Convênio, é que os Estados podem conceder isenções, incentivos e benefícios fiscais relativos ao ICMS, nos termos art. $155, \S 2^{\circ}$, XII, g, da CF. O STF há muito tem assentado que tampouco se admitem incentivos disfarçados, como a concessão de crédito presumido, o que, aliás, já constava expressamente do art. $1^{\circ}$, parágrafo único, III, da LC 24/75. Lembro, por todos, o que restou decidido na ADI 1.587, verbis: "Argüição de inconstitucionalidade de lei do Distrito Federal, que mediante a instituição de crédito presumido de ICMS, redundou em redução da alíquota efetiva do tributo, independentemente da celebração de convênio com afronta ao disposto no art. $155, \S 2^{\circ}$, XII, g, da Constituição Federal. Ação Direta julgada procedente.".

6. O que está em discussão, porém, não é propriamente a higidez do benefício concedido pelo Estado de Goiás, mas a possibilidade de o Estado de Minas Gerais, manu propria, anular os seus efeitos mediante glosa à apropriação de créditos relativa a operações estaduais efetuadas a partir daquele Estado. Pode, o Estado de Minas Gerais, indiscutivelmente, argüir a inconstitucionalidade do benefício fiscal concedido pelo Estado de Goiás em sede de Ação Direta de Inconstitucionalidade, sendo certo que este Supremo Tribunal tem conhecido e julgado diversas ações envolvendo tais conflitos entre Estados, do que é exemplo a ADI-2548. Mas a possibilidade de estabelecer a glosa, pura e simples, dos créditos apropriados em operação interestadual em que efetivamente tenha sido calculada e destacada a alíquota interestadual apresenta-se questionável em face da sistemática de tributação interestadual e da nãocumulatividade constitucionalmente consagradas, atentando-se para a orientação desta Corte, bem lembrada pela Requerente, no sentido de que inconstitucionalidades não se compensação, conforme a ADIMC 2.377, cujo relator foi o Min. Sepúlveda Pertence: "O propósito de retaliar preceito de outro Estado, inquinado da mesma balda, não valida a retaliação: inconstitucionalidades não se compensam”.

A análise constitucional exigiria que se definisse se o Estado de destino da mercadoria pode restringir ou glosar a apropriação de créditos de ICMS quando, embora destacados os $12 \%$ na operação interestadual, o Estado de origem tenha concedido crédito presumido ao estabelecimento lá situado, reduzindo, assim, na prática, o impacto da tributação.

7. Contudo, a questão constitucional se apresenta de modo indireto, porquanto, conforme se infere da inicial, a glosa foi feita com suporte em atos normativos infralegais, quais sejam, os arts. 62, parágrafo único, $68 \mathrm{e}$ 71, VI, do Decreto $n^{\circ} 38.104 / 96$ e o artigo $1^{\circ}$ da Resolução no $3.166 / 2001$, do Secretário da Fazenda do Estado de Minas Gerais. Conforme a própria Requerente, as leis que supostamente dariam suporte a tais atos infralegais, em verdade, não tinham tal alcance. A Requerente entende que a LC 24/75, que "Dispõe sobre os convênios para a concessão de isenções do imposto sobre operações relativas à circulação de mercadorias, e dá outras providências", não foi recepcionada no ponto pela Constituição de 1988 e que, de qualquer modo, seu conteúdo não autorizaria o quanto contigo no Decreto e na Resolução. 
Também destaca, em seu Recurso Extraordinário, que "A Lei Estadual n 6.763 , de 26/12/75, com a redação vigente à época dos fatos geradores (13/07/2001 a 31/08/2002), não previa, no tocante ao crédito do impostos (artigos 28, 29, 30, 31 e 32), qualquer restrição... Tal limitação ao crédito só foi introduzida na Lei $\mathrm{n}^{\circ} 6.763 / 75$ pelo artigo 30 da Lei Estadual $\mathrm{n}^{\circ}$ 14.699 , de 06/08/2003, a qual introduziu o $\S 5^{\circ}$ ao art. 28 da Lei 6.763/75..." (fl. 170).

E prossegue: "Assim, não é necessário muito esforço para se perceber que as normas do Regulamento do ICMS (artigos 62, parágrafo único; 68 e 71, VI, do Decreto n ${ }^{\circ} 38.104 / 96$ ), bem como o art. $1^{\circ}$ da Resolução n ${ }^{\circ}$ 3.166 , de 11/07/2001, extrapolaram o poder regulamentar, instituindo uma nova vedação ao crédito não prevista na Lei Estadual $n^{\circ} 6.763 / 75$, em flagrante ofensa também ao artigo 150, I, da Carta Magna e ao art. 99 do Código Tributário Nacional."

8. Cuida-se, pois, ao que tudo indica, de matéria a ser resolvida pela ótica infraconstitucional, não sendo o caso de se acautelar o resultado do julgamento de Recurso Extraordinário que provavelmente não venha sequer a ser admitido.

Destaco que a ora Requerente interpôs o pertinente Recurso Especial e que não há óbice a que venha a buscar a tutela cautelar junto ao Superior Tribunal de Justiça, até porque se trata de postulações independentes, conforme, aliás, já destaquei na AC 639 QO: "Interposição simultânea de recursos especial e extraordinário, ambos admitidos. Postulação de medidas liminares perante o STJ e o STF. Garantias independentes, especialmente considerada a urgência ínsita aos pedidos cautelares."

9. Ante o exposto, nego seguimento à ação cautelar, prejudicada a análise da liminar.

Publique-se.

Intimem-se.

Brasília, 07 de maio de 2010.

Ministra Ellen Gracie

Relatora. $^{283}$

Além disso, as medidas sancionatórias previstas na Lei Complementar n ${ }^{\circ} 24 / 75$, se aplicadas, ofendem diversos princípios constitucionais.

283 BRASIL. Supremo Tribunal Federal. Medida Cautelar em Ação Cautelar $n^{\circ}$ 2611/MG. Relatora: Min. Ellen Gracie. Julgamento: 07 maio 2010. Divulgação: 12 maio 2010. Publicação: DJe-085 13 maio 2010. 
Ora, conforme exposto no item 3.2., ao dispor sobre a não cumulatividade do ICMS, a Constituição Federal impôs apenas duas limitações ao direito de crédito: isenção ou não incidência. Tendo em vista que, exceto as limitações constitucionais, a não cumulatividade não pode ser de forma alguma limitada pela legislação infraconstitucional, é forçoso reconhecer que a vedação ao crédito prevista na Lei Complementar no 24/75 só pode ocorrer se o incentivo fiscal concedido irregularmente se caracterizar como isenção ou não incidência ${ }^{284}$ :

Por essa razão, conferindo-se interpretação conforme a Constituição Federal ao artigo $8^{\circ}$, I da Lei Complementar, somente os benefícios da isenção e não-incidência podem ensejar a anulação do crédito eventualmente apropriado pelo destinatário da mercadoria ou serviço, sendo que os demais benefícios fiscais, como crédito presumido, e financeiros, como devolução do imposto pago, ainda que concedidos unilateralmente, não pode ensejar a glosa do crédito pela Unidade Federada de destino. ${ }^{285}$

As penalidades impostas pelo artigo $8^{\circ}$ da Lei Complementar $n^{\circ}$ 24/75 ofendem ainda a estrutura federativa do Brasil e a distribuição de competências tributárias pela Constituição Federal.

Se a Lei Complementar determina que o Estado de origem deve exigir o ICMS que deixou de ser recolhido em virtude do benefício irregularmente concedido, não poderia, cumulativamente, determinar o estorno do crédito do destinatário da operação, pois, nessa situação, o imposto seria efetivamente recolhido na origem, preservando o direito ao crédito na operação subsequente. O efeito imediato da exigência do imposto no Estado de origem é garantir o direito de crédito do adquirente no Estado de destino. ${ }^{286}$ Nesse sentido, José Eduardo Soares de Melo esclarece:

O questionamento da legitimidade do incentivo concedido pelos Estados $\mathrm{B}$ ou C somente pode ser promovido pela via judicial apontada (ADIn) para tornar ineficaz os efeitos do incentivo (crédito presumido) em seu

${ }^{284}$ OLIVEIRA, Julio Maria de; MIGUEL, Carolina Romanini. Guerra Fiscal ou Terrorismo Estatal. In: SANTI, Eurico Marcos Diniz de; ZILVETI, Fernando Aurelio (Coords.). Tributação Empresarial. São Paulo: Saraiva, 2009, p. 123.

285 Ibid., p. 130.

286 MOREIRA, Gilberto Ayres. A “Guerra Fiscal” e os limites ao princípio da não-cumulatividade do ICMS. Revista de Direito Tributário, Rio de Janeiro: Malheiros, n. 85, 2002, p. 245. 
nascedouro (face aos contribuintes dos Estados B, C). Nesse caso, compete exclusivamente ao Fisco dos Estados B e C (após decisão em ADIn) promover a cobrança do valor tributário do contribuinte nos Estados B e C (relativamente aos futuros negócios mercantis), razão pela qual não há fundamento para se exigir qualquer valor tributário do contribuinte do Estado destinatário (A), especialmente porque não se trata de 'isenção ou não-incidência' (casos de descabimento de crédito). ${ }^{287}$

Não admitir o direito de crédito do ICMS recolhido em virtude da sanção prevista no inciso II do artigo $8^{\circ}$ da Lei Complementar caracteriza não apenas ofensa ao princípio da não cumulatividade, mas também enriquecimento indevido do Estado de destino. ${ }^{288}$

Ademais, o Estado de destino não pode exigir o imposto que não foi recolhido no Estado de origem da operação - imposição que tem sido aplicada por alguns Estados - ou, ainda, exigir que o Estado de origem cobre a diferença do imposto que não foi recolhida em virtude do incentivo concedido de forma indevida. ${ }^{289}$

Isso porque o Estado de destino não pode exigir tributo que, de acordo com a Constituição Federal, é de competência de outro Estado. Ora, o fato de o Estado de origem não exigir o tributo não habilita o Estado de destino a cobrar a diferença, já que competência tributária é indelegável. O fato de um Estado renunciar a receita, por meio de incentivos fiscais, não transfere a competência tributária para os demais Estados, em virtude da rigidez da distribuição de competências no Texto Constitucional.

Também não há como obrigar o Estado de origem a cobrar a diferença do imposto, uma vez que todos os entes da Federação Brasileira gozam de autonomia política e financeira. A consequência viável seria eventual responsabilização nos termos da Lei Complementar $n^{\circ}$ 101/2000 (Lei de Responsabilidade Fiscal). ${ }^{290}$

${ }^{287}$ MELO, Fábio Soares de. .Incentivos Fiscais e Segurança Jurídica. In: MARTINS, Ives Gandra da Silva; ELALI, André; PEIXOTO, Marcelo Magalhães. Incentivos Fiscais - Questões Pontuais nas Esferas Federal, Estadual e Municipal. São Paulo: MP Editora, 2007, p. 242.

288 OLIVEIRA, Julio Maria de; MIGUEL, Carolina Romanini. Guerra Fiscal ou Terrorismo Estatal. In: SANTI, Eurico Marcos Diniz de; ZILVETI, Fernando Aurelio (Coords.). Tributação Empresarial. São Paulo: Saraiva, 2009, p. 132.

289 Ibid., p. 133.

290 Ibid., p. 134. 
É importante destacar ainda que, em muitos casos, os Estados que aplicam as sanções previstas no artigo $8^{\circ}$ da Lei Complementar $n^{\circ}$ 24/75 também concedem incentivos fiscais unilateralmente, sem a observância da referida lei complementar, o que ofende o princípio da moralidade, previsto no artigo 37 da Constituição Federal.

Frise-se que alguns Estados vedam a apropriação de créditos decorrentes de operações realizadas com Estados que concedem incentivos fiscais, por meio de atos administrativos. É o caso, por exemplo, do Comunicado CAT n³6/2004 do Estado de São Paulo e da Resolução 3.166/2001 do Estado de Minas Gerais.

Ora, não há como os Estados vedarem o aproveitamento de crédito, por meio de atos dos Poderes Executivo ou Legislativo, pois há ofensa direta ao princípio da separação de poderes, na medida em que, conforme já destacamos, a única forma de questionar a regularidade dos incentivos fiscais é por meio do ajuizamento de ação declaratória de inconstitucionalidade.

Ao assim proceder, os Estados interferem na competência exclusiva do Poder Judiciário. Nesse sentido, inclusive, o Tribunal de Justiça de São Paulo já se posicionou:

\footnotetext{
TRIBUTÁRIO. ICMS. OPERAÇÕES INTERESTADUAIS Comunicado CAT 36/2004 que impede apropriação de crédito em operações interestaduais praticadas com determinados Estados da federação. Sentença terminativa do feito. Reforma- art. 155 , $\S 2^{\circ}$, inciso XII, alínea ' $\mathrm{g}$ ' da Constituição Federal que exige edição de lei complementar para concessão de benefícios fiscais, não financeiros. Inaptidão de ato infralegal fazer as vezes de meio de impugnação à constitucionalidade de leis, na medida em que pretendeu antecipar o resultado de ADIns apostas contra leis que instituíram tais benefícios. Concessão de Segurança. Recurso provido. ${ }^{291}$
}

No âmbito do Supremo Tribunal Federal, foi reconhecida a repercussão geral da matéria, para definir se os Estados tem autonomia administrativa e legislativa para glosar

291 BRASIL. Tribunal de Justiça do Estado de São Paulo. Apelação Mandado de Segurança n. 518.847.5/500. Relator: Desembargador Nogueira Diefenhaler. Julgamento: 23 jul. 2007. Órgão Julgador: $7^{\text {a }}$ Câmara de Direito Público. Publicação: 09 out. 2007. 
créditos decorrentes de operações incentivadas de forma irregular, mas que não foram objeto de ação judicial. Veja-se a decisão do Min. Joaquim Barbosa:

\section{3/10/2011 PLENÁRIO}

REPERCUSSÃO GERAL NO RECURSO EXTRAORDINÁRIO 628.075 RIO GRANDE DO SUL

RELATOR: MIN. JOAQUIM BARBOSA

RECTE.(S): GELITA DO BRASIL LTDA

ADV.(A/S): MARCELO SILVA POLTRONIERI E OUTRO(A/S)

RECDO.(A/S): ESTADO DO RIO GRANDE DO SUL

PROC.(A/S)(ES): PROCURADOR-GERAL DO ESTADO DO RIO GRANDE DO SUL

EMENTA: CONSTITUCIONAL. TRIBUTÁRIO. ICMS. GUERRA FISCAL. CUMULATIVIDADE. ESTORNO DE CRÉDITOS POR INICIATIVA UNILATERAL DE ENTE FEDERADO. ESTORNO BASEADO EM PRETENSA CONCESSÃO DE BENEFÍCIO FISCAL INVÁLIDO POR OUTRO ENTE FEDERADO. ARTS. $1^{\circ}, 2^{\circ}, 3^{\circ}, 102 \mathrm{e}$ $155, \S 2^{\circ}$, I DA CONSTITUIÇÃO FEDERAL. ART. $8^{\circ}$ DA LC 24/1975. MANIFESTAÇÃO PELA EXISTÊNCIA DE REPERCUSSÃO GERAL DA MATÉRIA.

Decisão: O Tribunal reconheceu a existência de repercussão geral da questão constitucional suscitada, vencido o Ministro Marco Aurélio. Não se manifestaram os Ministros Cezar Peluso, Gilmar Mendes e Cármen Lúcia.

Ministro JOAQUIM BARBOSA Relator

REPERCUSSÃO GERAL NO RECURSO EXTRAORDINÁRIO 628.075 RIO GRANDE DO SUL CONSTITUCIONAL. TRIBUTÁRIO. ICMS. GUERRAL FISCAL. CUMULATIVIDADE. ESTORNO DE CRÉDITOS POR INICIATIVA UNILATERAL DE ENTE FEDERADO. ESTORNO BASEADO EM PRETENSA CONCESSÃO DE BENEFÍCIO FISCAL INVÁLIDO POR OUTRO ENTE FEDERADO. ARTS. $1^{\circ}, 2^{\circ}, 3^{\circ}, 102$ e $155, \S 2^{\circ}$, I DA CONSTITUIÇÃO. ART. $8^{\circ}$ DA LC 24/1975. MANIFESTAÇÃO PELA EXISTÊNCIA DE REPERCUSSÃO GERAL DA MATÉRIA.

M A N I F E S T A Ç Ã O

O Senhor Ministro Joaquim Barbosa (Relator): Trata-se de recurso extraordinário (art. 102, III, a, c e d da Constituição) interposto de acórdão prolatado pelo Tribunal de Justiça do Estado do Rio Grande do Sul. 
Em seu acórdão, o Tribunal de origem entendeu ser constitucional e legítima legislações local e federal que permitiriam ao ente federado negar ao adquirente de mercadorias o direito ao crédito de ICMS destacado em notas fiscais, nas operações interestaduais provenientes de estados da Federação que concedessem benefícios fiscais inconstitucionais ou ilegais.

Em síntese, sustenta-se que o estorno dos créditos é inconstitucional e ilegal, pois ele:

a) Viola a regra da não-cumulatividade, na medida em que impede que o contribuinte credite-se do valor do tributo cobrado na operação precedente (art. 155, §2 ${ }^{\circ}$, I da Constituição); b) Ofende o pacto federativo, dado que nenhum ente federado pode declarar a inconstitucionalidade de legislação de outro membro da Federação (inconstitucionalidade do art. $8^{\circ}$ da LC 24/1975 - arts. $1^{\circ}, 2^{\circ}, 102$ e $155, \S$ $2^{\circ}$, I da Constituição); c) Adota presunção legal proibida, ao reconhecer sem possibilidade de discussão que todas as operações realizadas com empresas localizadas no Estado do Paraná são beneficiárias de incentivo fiscal viciado (invalidade do art. 16 da Lei estadual 8.820/1989, de acordo com a sistemática de compensação estabelecida na Lei Complementar 87/1996).

Ante o exposto, pede-se a reforma do acórdão recorrido, para assegurar o direito ao creditamento integral do valor destacado na respectiva nota fiscal que acoberta a entrada do bem (ICMS), bem como para permitir a utilização dos créditos que teriam deixado de ser aproveitados em razão das ilícitas vedações. A intimação para ciência do acórdão foi publicada em 15.12.2006, portanto, em momento no qual inexigível o requisito da preliminar formal de repercussão geral (Fls. 174).

É o relatório.

Encaminho aos eminentes pares o exame da repercussão geral da matéria. O tema discutido neste recurso extraordinário é grave. Ele coloca em risco o desenvolvimento de atividades econômicas lícitas, a manutenção de empregos e a harmonia entre entes federados. É lícito presumir que estes casos perdem-se na classificação mais genérica de assuntos normalmente rotulados apenas como "ICMS - Não Cumulatividade" ou "ICMS - Crédito".

Esta Corte recebeu e recebe constantemente inúmeras ações diretas de inconstitucionalidade ajuizadas contra alegadas concessões inconstitucionais de incentivos tributários. Segundo a página de notícias desta Corte na internet, entre novembro de 2010 e janeiro de 2011, onze ações diretas de inconstitucionalidade sobre a concessão ilegal de benefícios fiscais foram protocoladas.

Para solucionar o que entendem como lesões aos interesses locais, alguns entes federados têm anulado unilateralmente os efeitos econômicos dos benefícios fiscais, com o uso da autonomia legislativa e administrativa que a Constituição lhes confere. Em resposta, o ente federado concessor do benefício retalia, com similar glosa de créditos, a concessão de mais 
incentivos ou a colocação de barreiras burocráticas desnecessariamente custosas e lentas.

A questão de fundo trazida nestes autos consiste em saber se os entes federados podem reciprocamente retaliarem-se por meio de sua autonomia ou, em sentido diverso, compete ao Poder Judiciário exercer as contramedidas próprias da atividade de moderação (checks and counterchecks).

Penso que a matéria transcende interesses individuais meramente localizados e tem relevância institucional incomensurável. Nesse sentido, anoto que é imprescindível determinar se as retaliações unilaterais têm amparo na Constituição, considerados dois valores fundamentais: a autonomia dos entes federais periféricos para dar efetividade à sua vontade política, de um lado, e a harmonia federativa, do outro.

Também registro que a imprensa tem noticiado o sistemático desrespeito às decisões desta Corte sobre a inconstitucionalidade de benefícios fiscais em matéria de ICMS, situação que afeta diretamente o apelo à retaliação unilateral como forma de se dar efetividade à interpretação que o ente federado faz da Constituição.

Por fim, quanto à possibilidade de se conferir a repercussão geral com ênfase no tema, e não na submissão de recurso específico ao requisito, lembro que esta Suprema Corte já considerou a hipótese viável, ao reconhecer a repercussão geral da matéria debatida no RE 242.689-RG, distribuído nesta Corte no ano de 2000.

Portanto, proponho à Corte que se reconheça a repercussão geral da matéria constitucional versada nestes autos. Entendo que, no caso dos autos, está presente o requisito da repercussão geral a que fazem alusão os arts. 102, $\S 3^{\circ}$, da Constituição, 543-A, $\S 1^{\circ}$, do Código de Processo Civil, e 323 do RISTF.

É como me manifesto. ${ }^{292}$

Até que se tenha a decisão, os incentivos fiscais são válidos ${ }^{293}$, não podendo os Estados que se julgam prejudicados impedir o creditamento do ICMS destacado na nota. Até que se tenha uma decisão, os incentivos fiscais gozam de presunção de legitimidade que não pode ser ilidida por atos administrativos de outros Estados. ${ }^{294}$

292 BRASIL. Supremo Tribunal Federal. Repercussão Geral no Recurso Extraordinário n. 628.075/RS. Relator: Ministro Joaquim Barbosa. Julgamento: 13 out. 2011. Órgão Julgador: Plenário. Publicação: 01 dez. 2011.

293 CARRAZZA, Roque Antonio. ICMS. 15. ed., rev. e ampl. até a EC 67/2011, de acordo com a Lei Complementar 87/1996 com suas ulteriores modificações. São Paulo: Malheiros, 2011, p. 393-394.

294 Ibid., p. 389. 
Por fim, não se pode admitir que os Estados transfiram aos contribuintes adquirentes das mercadorias a responsabilidade por verificar se as operações que realizam com contribuintes localizados em outros Estados são beneficiadas, se os incentivos são regulares e se há medidas judiciais questionando sua validade. ${ }^{295}$ Há contribuintes com volumes de operações diárias consideráveis, com diversos Estados, sendo impossível que o contribuinte verifique a legislação de cada Estado e a legalidade da atuação de seus fornecedores. Mesmo porque muitos benefícios não são concedidos com a redução do valor do ICMS destacado na Nota fiscal, mas por outras formas que sequer são refletidas nos documentos fiscais disponibilizados ao adquirente da operação:

Eventual pretensão fiscal nesse sentido praticamente 'engessaria' qualquer atividade comercial, principalmente nos segmentos que têm enorme volume diário de operações. Isto porque o adquirente das mercadorias passaria a ter a obrigação de exigir de seu fornecedor que, anexa a cada via da nota fiscal, fosse informada eventual concessão de benefício fiscal, além de apresentada cópia autenticada da guia de recolhimento do imposto incidente em cada operação, para, aí sim, apropriar-se do respectivo credito, sem risco de questionamento por parte das autoridades fiscais. Ora, tomadas as premissas acima fixadas acerca do princípio constitucional da não-cumulatividade do ICMS, esse tipo de exigência afigurar-se-ia totalmente desarrazoado. ${ }^{296}$

Resumindo todas as inconstitucionalidades das sanções previstas pelo artigo $8^{\circ}$ da Lei Complementar $n^{\circ} 24 / 75$, Carrazza conclui:

Em acréscimo às considerações supra, permitimo-nos aduzir que negar ao
contribuinte de boa-fé o direito de crédito em caso de concessão por outra
Unidade Federada, a descoberto de convênio, de benefícios de ICMS
também implica: a) enriquecimento sem causa do Estado de destino, que
estará indevidamente expandindo os lindes de sua competência tributária,
já que, por vias transversas, cobrará o tributo por operações realizadas
fora de seu território; b) imputação ao contribuinte do ônus de suportar os
efeitos emergentes de perlenga jurídica a ele todo estranha, já que da
exclusiva alçada dos Estados envolvidos em episódio da denominada
'guerra fiscal'; c) derrubar a presunção de legitimidade de que gozam as

${ }^{295}$ MELO, José Eduardo Soares de. O ICMS, os Benefícios Fiscais Concedidos unilateralmente por Certos Estados, as Medidas de Defesa Judicial e Extrajudicial Adotadas por outros Estados e Consequências para os Contribuintes. In: ROCHA, Valdir de Oliveira (Coord.). Grandes Questões Atuais do Direito Tributário, São Paulo: Dialetica, v. 9, p. 325-348, 2005, p. 334.

296 OLIVEIRA, Julio Maria de; MIGUEL, Carolina Romanini. Guerra Fiscal ou Terrorismo Estatal. In: SANTI, Eurico Marcos Diniz de; ZILVETI, Fernando Aurelio (Coords.). Tributação Empresarial. São Paulo: Saraiva, 2009, p. 128. 
normas instituidoras de benefícios fiscais, que só pode ser afastada pelo Poder Judiciário, observados os mecanismos consagrados pelo sistema jurídico; d) violação ao princípio da separação dos Poderes, porquanto não cabe ao Executivo julgar da validade de norma, invadindo competência privativa da Suprema Corte para dirimir conflitos entre Estados (art. 102, I 'f', da CF); e e) ofensa ao princípio da segurança jurídica, cuja finalidade maior é conferir estabilidade às relações sociais, preservando aos contribuintes que, de boa-fé, tomaram os créditos de ICMS 'a certeza do passado.'297

O que se verifica, portanto, é que no cenário atual a ferramenta para coibir a concessão irregular de benefícios, qual seja, questionamento via ação declaratória de inconstitucionalidade, não surte os efeitos necessários. Dessa forma, os Estados acabam perseguindo os contribuintes destinatários das operações irregulares, aplicando sanções que, conforme demonstrado, estão eivadas de diversas inconstitucionalidades, o que configura um verdadeiro terrorismo estatal.

Tal cenário apenas será alterado após uma reforma tributária que modifique a estrutura de tributação pelo ICMS, a fim de eliminar as distorções decorrentes das concessões de incentivos fiscais pelos Estados, que não prejudicam apenas os contribuintes envolvidos na operação, mas os próprios Estados e o desenvolvimento econômico do país. Passaremos, então, a analisar a possibilidade de reforma tributária, que envolva a alteração da tributação pelo ICMS.

${ }^{297}$ CARRAZZA, Roque Antonio. ICMS. 15. ed., rev. e ampl. até a EC 67/2011, de acordo com a Lei Complementar 87/1996 com suas ulteriores modificações. São Paulo: Malheiros, 2011, p. 389-390. 


\section{ANÁliSE DE RECENTE PROPOSTA DE REFORMA TRIBUTÁRIA}

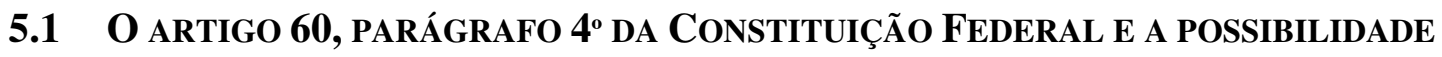 DE AMPLIAÇÃo E MODIFICAÇÃo de COMPETÊNCIAS TRIBUTÁRIAS E DE REFORMA TRIBUTÁRIA}

Restou demonstrado acima que a Constituição Federal Brasileira configura-se como rígida, inclusive no que se refere à repartição de competências tributárias.

Assim, o texto da Constituição Federal determina:

Art. 60. A Constituição poderá ser emendada mediante proposta:

I - de um terço, no mínimo, dos membros da Câmara dos Deputados ou do Senado Federal;

II - do Presidente da República;

III - de mais da metade das Assembléias Legislativas das unidades da Federação, manifestando-se, cada uma delas, pela maioria relativa de seus membros.

$\S 1^{\circ}$ - A Constituição não poderá ser emendada na vigência de intervenção federal, de estado de defesa ou de estado de sítio.

$\S 2^{\circ}$ - A proposta será discutida e votada em cada Casa do Congresso Nacional, em dois turnos, considerando-se aprovada se obtiver, em ambos, três quintos dos votos dos respectivos membros.

$\S 3^{\circ}$ - A emenda à Constituição será promulgada pelas Mesas da Câmara dos Deputados e do Senado Federal, com o respectivo número de ordem.

$\S 4^{\circ}$ - Não será objeto de deliberação a proposta de emenda tendente a abolir:

I - a forma federativa de Estado;

II - o voto direto, secreto, universal e periódico;

III - a separação dos Poderes;

IV - os direitos e garantias individuais. 
$\S 5^{\circ}$ - A matéria constante de proposta de emenda rejeitada ou havida por prejudicada não pode ser objeto de nova proposta na mesma sessão legislativa.

Dessa forma, para que se tenha qualquer alteração no seu texto, é necessária a aprovação por um processo especial e qualificado, previsto na própria Constituição. $\mathrm{O}$ artigo 60 da Carta Magna determina que a alteração constitucional deve ser aprovada por um quórum de 3/5 dos congressistas, em sistema de votação bicameral em dois turnos.

Ademais, embora parte da Constituição possa ser modificada, há um núcleo que não se sujeita a qualquer processo de reforma constitucional. Referido núcleo, composto pelas preposições inseridas no sistema constitucional como imodificáveis, denomina-se cláusulas pétreas.

André Elali esclarece:

Em síntese, afirma-se que uma cláusula pétrea representa uma limitação do poder constituído, por alguns denominado poder constituinte derivado. Trata-se, em verdade, de uma disposição inserida na Constituição que não pode se sujeitar a qualquer alteração que restrinja seu sentido, seu verdadeiro alcance, a preocupação expressada pelo constituinte. Neste sentido, uma cláusula pétrea constitui, como advertiu Karl Loewestein, um 'cerne imodificável' e/ou uma efetiva ‘disposição intangível. ${ }^{298}$

A finalidade é manter a estabilidade da ordem fundamental do Estado, permitindo reformas que adéquem a norma à realidade social, de acordo com transformações políticas, sociais, culturais e econômicas.

Ou seja, busca-se manter a estabilidade do texto, a manutenção de seu sentido, reconhecendo-se, entretanto, sua suscetibilidade à transformação, ao desenvolvimento, ao aperfeiçoamento da sociedade e do próprio Estado. Daí decorre a necessidade de previsão de regras sobre sua reforma.

298 ELALI, André. O Federalismo Fiscal Brasileiro e o Sistema Tributário Nacional. São Paulo: MP Editora, 2005, p. 53-54. 
No sistema brasileiro, as emendas constitucionais não podem modificar todo o texto da Constituição Federal, uma vez que seu artigo 60 limita as possibilidades de modificação, com o objetivo de que não haja a transformação de sua base fundamental.

Infere-se, da previsão constitucional, que não é possível uma proposta de emenda constitucional que tenha como tendência abolir a forma federativa do Estado.

Assim, é expressamente proibida reforma constitucional que objetive impor o exercício do poder político de forma concentrada, ou seja, instituir um Estado unitário, devendo-se manter o Estado como uma Federação em que coexistem entes autônomos.

Isso não significa que não possa haver uma reformulação no âmbito da estrutura federativa. Convém lembrar que não existe um modelo único de Federação, "forma de Estado, um sistema de composição de forças, interesses e objetivos que podem variar, no tempo e no espaço, de acordo com as características, as necessidades e os sentimentos de cada povo" 299 , cabendo a cada Estado instituir essa forma de governo nos moldes em que julgar adequada às suas necessidades particulares.

Assim, é cabível a reforma que altere a estrutura federativa, desde que o Estado não abandone essa forma política.

Nessa linha, não se pode perder de vista que é necessário, ainda que se façam mudanças para que se mantenha a Federação, que se garanta a autonomia financeira dos entes federativos.

Todavia, a necessidade de manter a autonomia dos entes não impede que se altere, por emenda constitucional, a repartição de competências tributárias. Pois, como já restou consignado acima, a autonomia financeira não é garantida apenas por esta forma de distribuição de receitas tributárias.

299 CARRAZZA, Roque Antonio. Curso de Direito Constitucional Tributário. 19. ed., rev. e ampl. até a EC 39/2002. São Paulo: Malheiros, 2003, p. 84. 
Além da repartição de competências tributárias, demonstrou-se que há outros instrumentos que viabilizam a autonomia de entes federativos, tais como a transferência de receitas tributárias e a criação de fundos e participação.

Ademais, demonstrou-se que a rígida partilha de competências tributárias está mais relacionada com a proteção ao contribuinte, para que não sofra um excesso de tributação, do que propriamente com a manutenção da autonomia dos entes federados.

Nesse sentido, não há nenhum impedimento para que, por meio de reforma constitucional, seja introduzida alteração na repartição de competências tributárias, desde que se mantenha, ainda que por outros instrumentos, a autonomia financeira dos entes federados.

Para que a estrutura federativa não seja abolida, é imprescindível que se mantenha a autonomia dos entes, mas não é obrigatório que se mantenha a distribuição de competências atualmente vigentes.

\subsection{Análise da Proposta de Emenda Constitucional 233/2008 no TOCANTE À REFORMA TRIBUTÁRIA DO ICMS}

Conforme exposto acima, a atribuição de competência para os Estados instituírem o ICMS, principal tributo sobre o consumo, resultou na chamada "guerra fiscal". Daniel Monteiro Peixoto destaca que "são 27 legislações diferentes em âmbito local, propiciando ampla desigualdade na cobrança do tributo, gerando desequilíbrios concorrenciais entre as empresas e insegurança dos contribuintes na hora da definição do local de investimento",300.

Esse é o principal aspecto a ser abordado em uma reforma tributária que envolva a alteração do atual ICMS.

300 PEIXOTO, Daniel Monteiro. Guerra Fiscal via ICMS: Controle dos Incentivos Fiscais e os Casos "FUNDAP" e "COMUNICADO CAT N. 36/2004". In: MARTINS, Ives Gandra da Silva; ELALI, André; PEIXOTO, Marcelo Magalhães. Incentivos Fiscais - Questões Pontuais nas Esferas Federal, Estadual e Municipal. São Paulo: MP Editora, 2007, p. 75. 
Já no Governo de Fernando Henrique Cardoso, foi apresentada a Proposta de Emenda Constitucional $n^{\circ} 175 / 1995$, que visava, entre outros aspectos, alterar a tributação do ICMS. Também, no Governo Lula, foi apresentada a Proposta de Emenda Constitucional $\mathrm{n}^{\mathrm{o}}$ 41/2003, posteriormente alterada pela Proposta de Emenda Constitucional $n^{\circ} 284 / 2004$.

Por último, temos a Proposta de Emenda Constitucional no 233/2008, que será aqui analisada. Um dos principais objetivos na reforma veiculada pela referida emenda é uniformizar o ICMS e extinguir com a guerra fiscal. Vejam-se os trechos da Exposição de Motivos do projeto referentes ao ICMS:

No tocante ao imposto de competência estadual sobre operações relativas à circulação de mercadorias e sobre prestações de serviços de transporte interestadual e intermunicipal e de comunicação (ICMS), tem-se, atualmente, um quadro de grande complexidade da legislação. Cada um dos Estados mantém a sua própria regulamentação, formando um complexo de 27 (vinte e sete) diferentes legislações a serem observadas pelos contribuintes. Agrava esse cenário a grande diversidade de alíquotas e de benefícios fiscais, o que caracteriza o quadro denominado de "guerra fiscal".

Para solucionar essa situação, a proposta prevê a inclusão do art. 155-A na Constituição, estabelecendo um novo ICMS em substituição ao atual, que é regido pelo art. 155, II, da Constituição, o qual resta revogado.

A principal alteração no modelo é que o novo ICMS contempla uma competência conjunta para o imposto, sendo mitigada a competência individual de cada Estado para normatização do tributo. Assim, esse imposto passa a ser instituído por uma lei complementar, conformando uma lei única nacional, e não mais por 27 leis das unidades federadas.

Dada a peculiaridade dessa lei complementar, que vai além da norma geral, fazendo as vezes de lei instituidora do imposto para cada Estado e o Distrito Federal, são propostas, no $\S 3^{\circ}$ do art. 61 da Constituição, regras especiais para a iniciativa dessa norma, que ficará a cargo do Presidente da República ou de um terço dos Senadores, dos Governadores ou das Assembléias Legislativas, sendo que nessas hipóteses deverão estar representadas todas as Regiões do País. Tal configuração tem o objetivo de prover maior estabilidade à legislação do imposto, que, com isso, estará sujeita a um menor volume de propostas de alteração.

$\mathrm{O} \S 5^{\circ}$ do art. 155-A determina que a regulamentação do imposto também será unificada, devendo ser editada, nos termos do $\S 7^{\circ}$ do mesmo artigo, por um órgão colegiado dos Estados e do Distrito Federal. Esse órgão está delineado nos moldes do atual Conselho Nacional de 
Política Fazendária (Confaz); assim, passaremos a denominá-lo, para efeito de simplificação de sua remissão, de novo Confaz.

Mais uma vez, em função da peculiaridade do modelo proposto, com suas regras nacionais sendo aplicáveis diretamente pelos Estados e julgadas nas respectivas justiças estaduais, prevê-se alteração no art. 105 da Constituição, conferindo-se ao Superior Tribunal de Justiça a competência para o tratamento das divergências entre os Tribunais estaduais na aplicação da lei complementar e da regulamentação do novo ICMS.

$\mathrm{O} \S 1^{\circ}$ do art. 155-A, em seu inciso I, define que o imposto será nãocumulativo, cabendo a lei complementar delinear os termos da aplicação dessa não-cumulatividade, sendo que o inciso II já estabelece que não implicarão crédito do imposto as operações e prestações que não forem objeto de gravame do tributo.

$\mathrm{Na}$ esteira do ICMS atual, o inciso III do $\S 1^{\circ}$ estabelece para o novo ICMS a incidência sobre as importações. É prevista também a incidência do novo ICMS sobre os serviços não sujeitos ao ISS que sejam prestados conjuntamente com operações e prestações sujeitas ao ICMS, evitando-se fugas de tributação das imposições estaduais e municipais.

Também em consonância com as regras estabelecidas para o atual ICMS, no inciso IV do $\S 1^{\circ}$, são previstas as seguintes imunidades: para as exportações, com a garantia de manutenção e o aproveitamento do crédito fiscal do imposto; para o ouro, quando negociado como ativo financeiro; e para as prestações de serviço de comunicação nas modalidades de radiodifusão sonora e de sons e imagens de recepção livre e gratuita.

$\mathrm{O} \S 2^{\circ}$ do art. 155-A disciplina o sistema de definição das alíquotas do imposto. No geral, as alíquotas do novo ICMS serão limitadas àquelas definidas pelo Senado Federal, que deverá estabelecer as alíquotas em que serão enquadráveis os bens e serviços, definindo, dentre elas, aquela que será a alíquota padrão do imposto, aplicável a todas as hipóteses não sujeitas a outra alíquota especial. Caberá ao novo Confaz propor ao Senado Federal o enquadramento de bens e serviços nas alíquotas diferentes da padrão. O Senado aprovará ou rejeitará as proposições, aplicando-se a alíquota padrão para as propostas rejeitadas.

A proposta prevê que a lei complementar definirá mercadorias e serviços que poderão ter sua alíquota aumentada ou reduzida por lei estadual, bem como os limites e condições para essas alterações. Essa previsão resguarda um espaço de autonomia para os Estados terem gerência sobre o tamanho de suas receitas, preservando um poder de recomposição de arrecadação que será importante na transição do modelo, evitando a necessidade de se estabelecer as alíquotas pelo topo.

No mesmo sentido, o art. $4^{\circ}$ prevê a não aplicação dos princípios da anterioridade e da noventena ao novo ICMS, excepcionalmente nos dois primeiros anos de sua implementação. Tal medida se justifica em função da magnitude das mudanças a serem levadas a efeito, permitindo, de forma excepcional, uma capacidade de reação mais célere dos Entes na 
hipótese de um declínio abrupto e inesperado de suas receitas. Assegurando-se um período mínimo de não-surpresa aos contribuintes, está previsto um prazo de 30 dias para eventuais alterações de legislação que impliquem majoração do imposto nesse período.

Ainda na linha de estabelecer segurança para os Estados na transição do modelo, é criado um Fundo de Equalização de Receitas (FER), a ser regulamentado por lei complementar, e financiado por uma vinculação de recursos (art. 159, II, "d" da Constituição) que substitui a parcela de 10\% do IPI atualmente transferida aos estados proporcionalmente à exportação de produtos industrializados, além de outros recursos definidos na lei complementar. No art. 5o da PEC, estabelece-se que recursos do FER deverão ser utilizados de forma decrescente para a compensação dos Estados pela desoneração das exportações e de forma crescente para a equalização dos efeitos da Reforma Tributária.

O objetivo dessa proposta é permitir que os Estados que ganham com a mudança possam contribuir parcialmente para a compensação dos eventuais perdedores, havendo a garantia de que, em nenhuma hipótese, serão reduzidas as transferências do FER para Estados que tenham perda de receita do ICMS em decorrência da Reforma. Os Estados que vierem a dar continuidade a políticas de renúncia de receitas no âmbito da guerra fiscal não terão direito aos recursos do FER, nos termos do art. 10 da PEC, sujeitando-se também à interrupção do recebimento de transferência dos recursos do Fundo de Participação dos Estados (FPE) e do Fundo Nacional de Desenvolvimento Regional.

Atentando para a questão do controle da carga tributária, está previsto, no art. $9^{\circ}$ da PEC, tal como para a transição dos tributos federais, que lei complementar poderá estabelecer limites e mecanismos de ajuste da carga tributária do ICMS, relativamente aos exercícios em que forem implementadas as alterações propostas.

$\mathrm{O} \S 3^{\circ}$ do art. 155-A estabelece que nas operações e prestações interestaduais, o imposto pertencerá preponderantemente ao Estado de destino da mercadoria ou serviço, ficando o equivalente à incidência de $2 \%$ do imposto para o Estado de origem. Caberá a lei complementar definir a forma como será tecnicamente manejado o modelo para que esse princípio seja atendido. Entretanto, em vista de que exige condições bastante especiais para sua execução, são propostos comandos que permitem à lei complementar estabelecer a exigência do imposto pelo Estado de origem das mercadorias e serviços, por meio de um modelo de câmara de compensação entre as unidades federadas.

Na mesma linha de prover o sistema normativo de medidas que permitam a boa aplicação de possíveis modelos a serem definidos em lei complementar para aplicação do princípio do destino no novo ICMS, é proposta a regra a ser inserida no art. 34 da Constituição, prevendo hipótese de intervenção federal na unidade federada que retiver parcela do novo ICMS devido a outra unidade da Federação. A inserção de dispositivo no art. 36 da Constituição prevê que a proposição de tal intervenção ficará a cargo do Poder Executivo de qualquer Estado ou do Distrito Federal. 
$\mathrm{O} \S 4^{\circ}$ do art. 155-A determina que as isenções ou quaisquer incentivos ou benefícios fiscais vinculados ao imposto serão definidos pelo novo Confaz e deverão ser uniformes em todo território nacional, salvo no caso de hipóteses relacionadas aos regimes especiais de micro e pequenas empresas e a regimes aduaneiros especiais, as quais poderão ser definidas em lei complementar. A alteração no $\S 6^{\circ}$ do art. 150 da Constituição estabelece a exceção da edição de tais benefícios fiscais pelo novo Confaz, tornando desnecessária a edição de norma autônoma do Estado para tratar dessa matéria.

$\mathrm{O} \S 6^{\circ}$ do art. 155-A define que caberá a lei complementar estabelecer grande parte do arcabouço normativo do novo ICMS, dispondo sobre fatos geradores e contribuintes; base de cálculo, de modo que o próprio imposto a integre; local das operações e prestações; regime de compensação do imposto; garantia do aproveitamento do crédito do imposto; substituição tributária; regimes especiais ou simplificados de tributação; processo administrativo fiscal; competências e o funcionamento do novo Confaz; sanções aplicáveis aos Estados e ao Distrito Federal e seus agentes, por descumprimento das normas que disciplinam o exercício da competência do imposto e o respectivo processo de apuração dessas infrações.

$\mathrm{O} \S 7^{\circ}$ do art. 155-A define que compete ao novo Confaz, além de editar a regulamentação do novo ICMS, autorizar a transação e a concessão de anistia, remissão e moratória, a serem definidas em leis estaduais ou distrital; estabelecer critérios para a concessão de parcelamento de débitos fiscais; fixar as formas e os prazos de recolhimento do imposto; estabelecer critérios e procedimentos de controle e fiscalização extraterritorial; e exercer outras atribuições definidas em lei complementar.

No $\S 8^{\circ}$ do art. 155-A são definidas as sanções que serão aplicáveis aos Estados, ao Distrito Federal e aos agentes públicos desses entes em função do descumprimento das normas que disciplinam o exercício da competência do novo ICMS.

Nos termos do art. 12, II, da PEC, o novo ICMS somente vigerá a partir de $1^{\circ}$ de janeiro do $8^{\circ}$ (oitavo) ano subseqüente ao da promulgação da Emenda. $\mathrm{O}$ art. $3^{\circ}$, I da PEC estabelece que nesse período de transição o atual ICMS terá suas alíquotas interestaduais gradativamente reduzidas, aproximando-se da aplicação da preponderância do princípio do destino que norteará o novo ICMS. Nesse período, poderão ser aplicadas ao atual ICMS, pela via da lei complementar, as regras para a cobrança na origem que serão definitivas no novo ICMS, de forma a evitar problemas de ordem econômica e de evasão fiscal que a aplicação pura e simples das alíquotas pode ensejar.

$\mathrm{O}$ art. $3^{\circ}$, III da PEC também estabelece uma gradativa redução do prazo de apropriação dos créditos de ICMS de mercadoria destinadas ao ativo permanente, equacionando o modelo preconizado originalmente na Lei Complementar no 87, de 13 de setembro de 1996, e alterações, cuja implementação vem sendo adiada sistematicamente. 
A proposta prevê, para enfrentamento das desigualdades regionais, a instituição do Fundo Nacional de Desenvolvimento Regional (FNDR), de que trata o art. 161, IV da Constituição, que permitirá a coordenação da aplicação dos recursos da Política de Desenvolvimento Regional, introduzindo um importante aprimoramento nas políticas atualmente praticadas. Haverá ampliação do montante de recursos destinados à Política de Desenvolvimento Regional, com a destinação ao FNDR, nos termos do art. 159, II, "c" da Constituição, de montante equivalente a $4,8 \%$ da receita de IR e IPI, considerando o modelo de partilha hoje vigente.

Também está prevista uma ampliação do escopo da Política de Desenvolvimento Regional, por meio da possibilidade de aplicação de até $5 \%$ dos recursos nas regiões menos desenvolvidas das regiões Sul e Sudeste, garantindo-se assim a ampliação do montante de recursos da PDR para todas as regiões.

A proposta garante também que pelo menos $60 \%$ dos recursos do FNDR serão aplicados em financiamentos ao setor produtivo, através dos instrumentos atualmente existentes, visando a evitar a descontinuidade do modelo já implementado.

Por outro lado, a proposta prevê a criação de novos instrumentos para a alocação dos recursos do FNDR, permitindo que haja aplicação de recursos em investimentos estruturantes, que deverão observar diretrizes estabelecidas pelas superintendências regionais e pelo Ministério da Integração Nacional (art. 161, IV, "b" e $\S 3^{\circ}$ ). Complementando o desenho da nova política, a proposta contempla que os recursos do FNDR poderão ser transferidos diretamente para fundos de desenvolvimento estaduais, para alocação em investimentos estruturantes ou apoio ao setor produtivo, permitindo que se busquem sempre as formas mais eficientes para atingir os objetivos de desenvolvimento econômico e social (art. $161, \mathrm{IV}$, “c” e $\S 4^{\circ}$ ).

A nova Política de Desenvolvimento Regional substituirá com grandes vantagens a utilização da guerra fiscal como instrumento de desenvolvimento. Para evitar mudanças bruscas no modelo atual, propõese que sua introdução seja feita de forma gradual, nos termos do art. $7^{\circ}$ da PEC.

Também em linha com o objetivo de melhorar o modelo federativo brasileiro, propõe-se, mediante alteração do parágrafo único do art. 158, que o critério de partilha municipal da parcela de ICMS atualmente transferida com base no valor adicionado passe a ser definido por lei complementar. Trata-se de mudança importante introduzida na proposta a partir de demanda de entidades municipalistas de caráter nacional, que encontra fundamento nos grandes desequilíbrios na distribuição dos recursos entre os Municípios, beneficiando desproporcionalmente aqueles 
onde estão localizadas grandes unidades industriais, em detrimento dos demais. $^{301}$

Além de criar um IVA-federal que não será aqui abordado, as alterações referentes ao ICMS propõem a sua substituição por um IVA-Estadual, com regime diverso do atualmente vigente.

Propõe-se que o IVA-E, ICMS, seja regulado apenas por uma lei complementar, única e nacional, extinguindo as 27 legislações vigentes. Será ainda regulamentado por um órgão colegiado presidido por um representante da União Federal, que não tem direito a voto e por representantes dos Estados.

A lei complementar será de competência da União Federal, cabendo a sua edição ao Presidente da República ou a um terço dos membros do Senado Federal, a um terço dos Governadores ou às Assembleias Legislativas, hipóteses nas quais deverão estar representadas todas as regiões do país.

Obviamente, conforme destacado por José Mauricio Conti, as alterações em questão provocam aumentos e/ou reduções na arrecadação de tributos. ${ }^{302}$ Ademais, há grande alteração no que se refere à competência para legislar referente ao ICMS.

Tais alterações não podem, entretanto, ser consideradas inconstitucionais, a priori, por ofensa ao artigo $60, \S 4^{\circ}$ da Constituição Federal, ainda que haja redução de receita de um ente federativo. Tal análise está sujeita a verificação de eventual supressão de autonomia financeira de qualquer um dos entes da Federação.

Não havendo essa ofensa, não há nenhum impedimento para que se introduza, por emenda constitucional, reforma nesse sentido. Note-se, inclusive, que ainda que haja

301 BRASIL. Subchefia de Assuntos Parlamentares. EM n 00016/MF. Brasília: 26 fev. 2008. Disponível em: <http://www.planalto.gov.br/ccivil_03/projetos/EXPMOTIV/MF/2008/16.htm>. Acesso em: 23 set. 2012.

${ }^{302}$ CONTI, José Mauricio. Federalismo Fiscal e Reforma Tributária: Utopia ou Realidade? In: SCHOUERI, Luis Eduardo (Org.). Direito Tributário. Homenagem a Paulo de Barros Carvalho. v. 1. São Paulo: Quartier Latin, 2008, p. 910. 
supressão de competência tributária ou de competência para legislar sobre o ICMS, é possível manter a autonomia com a adoção de repartição de receitas e criação de fundos.

A PEC aqui citada, por exemplo, cria o Fundo de Equalização de Receitas (FER). José Mauricio Conti destaca que a intenção da criação do referido fundo é justamente compensar as perdas dos Estados com as modificações decorrentes da Emenda Constitucional. $^{303}$

Nesse contexto, partindo-se da premissa de que essencial à estrutura federativa é a autonomia financeira dos entes federativos e não a repartição de competências, é possível que se tenha uma reforma tributária com a alteração da competência para legislar sobre o ICMS, desde que se garanta a autonomia financeira de todos os entes federados.

Conforme já exposto acima, há, inclusive, outros países federativos que atribuem a competência para legislar sobre o IVA para a União e garantem a autonomia financeira dos Estados-membros por meio do repasse de recursos. O exemplo mais citado é o da Alemanha. Misabel Abreu Machado Derzi e Igor Mauler Santiago exemplificam:

A transposição para o Brasil do modelo alemão, em que o IVA é integralmente disciplinado por normas federais uniformes, teria de ser acompanhada da importação de outros institutos peculiares àquele país, como o Conselho Federal, que dá aos Estados a faculdade de exercer uma forte interferência no processo de elaboração das leis da União, que podem afetar as suas finanças.

O Conselho Federal é formado pelos governadores dos Estados, por alguns dos seus secretários e por outros membros dos respectivos governos (Constituição da Alemanha, art. 51). Quem sair do governo estadual automaticamente sai do Conselho. A meta é atenuar a influência político-partidária, pois os integrantes de um governo estão fortemente pressionados pelos problemas administrativos de seu Estado. O Conselho Federal tem a iniciativa da elaboração de leis federais e pode vetar as leis aprovadas pela Câmara Federal que considere prejudiciais aos interesses estaduais. Assim, a uniformização das normas relativas ao IVA e a outros tributos não prejudica os Estados Federados.

${ }^{303}$ CONTI, José Mauricio. Federalismo Fiscal e Reforma Tributária: Utopia ou Realidade? In: SCHOUERI, Luis Eduardo (Org.). Direito Tributário. Homenagem a Paulo de Barros Carvalho. v. 1. São Paulo: Quartier Latin, 2008, p. 910. 
Interessante observar que no federalismo alemão o Legislativo estadual perde competência, mas os Executivos estaduais participam ativamente da função legiferante da União (federalismo de 'política conjunta', mais do que federalismo cooperativo).

Esta, de resto, a direção em que apontam os projetos de reforma tributária ultimamente apresentados no Congresso Nacional: unificação legislativa do ICMS e ampliação do papel do CONFAZ, que - embora perca a competência para autorizar incentivos tributários, que ficam inteiramente vedados - passa a elaborar o regulamento do imposto e a propor ao Senado o enquadramento dos produtos em cada uma das alíquotas previstas na lei complementar instituidora, entre outras funções.

$[\ldots]$

Voltando à Alemanha, tem-se ainda que a massa dos tributos existentes naquele país, não apenas o IVA, apesar de em grande parte instituída pela União, é administrada e arrecadada pelos Estados, inclusive o imposto sobre a renda. Finalmente, o seu sistema de partilha de recursos, talvez o mais complexo de todo o planeta, funciona efetivamente e é apto a equilibrar o padrão de qualidade dos serviços oferecidos ao povo de cada Estado. Ele não se baseia apenas em transferências verticais (União, Estados), mas ainda em distribuições horizontais, feitas entre os próprios Estados, com vistas à equalização e à redução das desigualdades. ${ }^{304}$

Dessa forma, temos que a proposta de reforma que visa à padronização da legislação do ICMS por lei complementar editada com a interferência da União Federal, limitando a competência legislativa dos Estados e a uniformização dos deveres administrativos e dos procedimentos por um regulamento único editado pelo CONFAZ, que terá validade em todos os Estados, vedando-se a adoção de normas estaduais, que serão limitadas às poucas exceções, não ofende nenhum dispositivo constitucional.

A proposta prevê ainda que incentivos fiscais serão instituídos pelo novo CONFAZ e deverão ser uniformes em todo o país. Os Estados que continuarem a conceder incentivos, desrespeitando as novas regras do imposto, deverão ser punidos, com a interrupção do repasse de recursos do FER e de transferências dos recursos do Fundo de Participação dos Estados (FPE) e do Fundo Nacional de Desenvolvimento Regional.

${ }^{304}$ DERZI, Misabel Abreu Machado; SANTIAGO, Igor Mauler. A Harmonização dos IVAS do Brasil para o desenvolvimento produtivo In: SARAIVA FILHO, Oswaldo Othon de Ponte; VASQUES, Sérgio; GUIMARÃES, Vasco Branco (Orgs.). IVA para o Brasil - Contributos para a Reforma da Tributação do Consumo. Belo Horizonte: Fórum, 2007, p. 533-534. 
Ademais, determina que a lei complementar deverá estabelecer sanções aos Estados e Distrito Federal, no caso de descumprimento das normas nacionais referentes ao IVA-E e estabelecer a harmonização do processo administrativo fiscal para o julgamento tanto de questões remanescentes do atual ICMS como do novo tributo proposto. As sanções podem ser multas, suspensão de direitos políticos, perda da função pública, indisponibilidade de bens e ressarcimento ao Erário e ação penal contra os representantes dos Estados e Distrito Federal. Essas medidas visam combater definitivamente a guerra fiscal.

A proposta determina também que o IVA-E não incidirá sobre as operações de exportações. Ademais, embora continue sendo não cumulativo, mantém o não reconhecimento de crédito no que se refere às operações e prestações sujeitas à alíquota zero, isenção, não-incidência e imunidade para compensação nas operações subsequentes. Essa é uma falácia da proposta, pois, conforme já exposto acima, a limitação ao direito de crédito desvirtua a não cumulatividade e se distancia da neutralidade da tributação.

Há previsão, ainda, de alíquotas uniformes. Quanto às operações interestaduais, o IVA-E pertencerá ao Estado de destino, e o Estado de origem terá direito ao repasse de 2\% do imposto cobrado. Na prática, propõe-se que o Estado de origem cobre o valor integral do imposto (a fiscalização pelo Estado de origem é mais eficaz), que deverá transferir a arrecadação correspondente ao Estado de destino, por uma câmara de compensação. No caso de descumprimento do repasse, propõe-se a intervenção federal na unidade federada que retiver os valores.

Vê-se, portanto, que, na verdade, o único empecilho para a reforma é uma questão política, de disputa de poderes entre os Entes da Federação. Nesse sentido, Ricardo Lobo Torres conclui:

Da matéria exposta podemos tirar algumas conclusões:

$[\ldots]$

A terceira aponta no sentido de que a unificação do IVA deveria passar pela redistribuição de competências no plano do federalismo, inspirandose em alguns modelos existentes no direito comparado, cabendo à União legislar sobre o tributo, aos Estados-membros administrá-los e participar do produto de sua arrecadação, e à União e aos Estados, 
compartilhadamente, julgar os litígios decorrentes de sua aplicação. Mas a desconfiança mútua entre Estados-membros e União e a inexistência de propostas racionais e fundamentadas para a repactuação do nosso federalismo fiscal dificultam tal reforma. Ademais seriam necessárias mudanças radicais no modelo do nosso federalismo fiscal com:

a) a adoção do princípio da origem para as saídas interestaduais;

b) a vedação de isenções e outras renúncias fiscais, com o que se obteria a neutralidade econômica do tributo e se evitaria a "guerra fiscal" entre os Estados, tornando-se dispensável o CONFAZ ou órgão similar;

c) a estruturação da base de cálculo e das alíquotas de forma a favorecer a equidade entre os Estados-membros. ${ }^{305}$

\subsection{A RESOLUÇÃO No 13 DE 2012}

Por fim, é importante destacar que em abril de 2012 o Senado Federal aprovou a Resolução $\mathrm{n}^{\circ} 13$ em substituição às alíquotas interestaduais de $7 \%$ e $12 \%$ pela alíquota de $4 \%$ no caso de operações interestaduais com bens e mercadorias importadas do exterior.

A referida Resolução objetiva reduzir os impactos da guerra fiscal e demonstra a preocupação e empenho do Governo em resolver o problema. No entanto, não soluciona definitivamente a questão, sendo apenas um remendo que ignora as demais distorções que hoje marcam o ICMS como os incentivos não relacionados com mercadorias importadas e o regime de substituição tributária.

Nesse contexto, embora a Resolução que entrou em vigor em $1^{\circ}$ de janeiro de 2013 resolva a questão da alíquota interestadual nas operações com mercadorias importadas, é imperioso que se realize uma reforma com total alteração da estrutura do ICMS a fim de eliminar também outras distorções.

305 TORRES, Ricardo Lobo. É possível a criação do IVA no Brasil? In: SARAIVA FILHO, Oswaldo Othon de Ponte; VASQUES, Sérgio; GUIMARÃES, Vasco Branco (Orgs.). IVA para o Brasil - Contributos para a Reforma da Tributação do Consumo. Belo Horizonte: Fórum, 2007, p. 34-35. 


\section{CONCLUSÃO}

Conforme exposto acima, entre os tributos indiretos no Brasil, o ICMS constitui o caso mais relevante, por ser o imposto de maior arrecadação em âmbito nacional e a mais significativa fonte de recursos dos Estados da Federação.

Demonstrou-se, ademais, que, embora enquadrado como tributo não cumulativo, a fim de afastar o "efeito cascata", a ausência de uma política nacional uniforme possibilitou que se instalasse em nosso sistema uma série de restrições ao aproveitamento do crédito do ICMS, alterando profundamente o perfil da não cumulatividade.

Alocado às diversas unidades subnacionais integrantes da Federação, o ICMS acirrou a guerra fiscal, praticada, principalmente, por meio da concessão de incentivos à margem da legislação vigente, provocando profundas assimetrias e distorções em nosso sistema tributário, bem como a ruptura com diversos princípios gerais e outros especificamente tributários consagrados em nossa Constituição, como os da livre concorrência, capacidade contributiva e não cumulatividade, por exemplo.

O conflito entre eficiência arrecadatória e justiça fiscal não pode ser desprezado no âmbito da tributação sobre o consumo. E a justiça fiscal, dentro de uma estrutura de um sistema tributário ideal, relaciona-se com equidade, igualdade e proporcionalidade.

Para que se obtenha uma estrutura tributária ideal, observando-se justiça fiscal, igualdade, equidade e proporcionalidade, mister se faz que se utilize um critério adequado de comparação para o tratamento isonômico com fundamento na justiça.

A circunstância de que cada tributo onera renda, patrimônio e consumo permite diferentes avaliações não apenas da justificação de tributos, mas também dos efeitos que tais indicadores têm sobre o sistema tributário. Assim, a utilização por um Estado de determinado critério mensurador da capacidade contributiva deve considerar os efeitos tributários econômicos de cada tributo em consonância com as necessidades de sua sociedade. 
Demonstrou-se que o consumo e o patrimônio também são meios legítimos para se apurar a capacidade econômica do contribuinte.

No que se refere à seletividade, concluímos que deve ser utilizada como instrumento de política econômica e fiscal, estimulando a prática de operações ou prestações consideradas úteis ou convenientes ao Estado e, em contrapartida, onerando outras que não sejam consideradas tão úteis ou convenientes.

A Constituição Federal estabelece a aplicação facultativa para o ICMS (artigo 155, $\S 2^{\circ}$, III), em função da essencialidade do produto. Não há, entretanto, um conceito determinado de seletividade/essencialidade na Carta Magna.

Restou demonstrado, assim, que o conceito de essencialidade pode variar de acordo com diversos elementos referentes à comunidade e ao tempo em que esta sociedade se localiza, para fins extrafiscais e da intervenção econômica, não podendo ser compreendido apenas em função das características específicas dos produtos.

Afirmamos que o conceito de "essencial" pode ser reformulado para se adequar as finalidades extrafiscais e de intervenção no domínio econômico, funções estas expressamente previstas para o IPI e para o ICMS, permitindo-se a interpretação do referido termo de forma não limitada à relação da essencialidade com a necessidade, finalidade e utilidade do produto.

Ainda que, com fins de intervenção/indução e não arrecadatórios, as normas com finalidade extrafiscal não perdem sua natureza tributária e, por isso, devem respeitar todos os princípios e demais normas tributárias, mesmo que, em algumas situações, a observância de um princípio afaste parcialmente ou mitigue a aplicação de outro princípio.

O artigo 151, I, da Constituição Federal confirma que as pessoas políticas são juridicamente iguais e que, por isso, a tributação deve ser uniforme em todo o território nacional. Não obstante, permite a concessão de incentivos fiscais para as pessoas políticas mais carentes, com o objetivo de promover o equilíbrio do desenvolvimento entre as diversas regiões. 
Por sua vez, o princípio da neutralidade também tem como objetivo garantir ordem (consistência) e unidade (coerência) ao sistema jurídico tributário, estabelecendo que os efeitos da tributação não devem ter influência sobre a decisão dos agentes econômicos, de forma a evitar distorções e consequente ineficiência no sistema econômico.

Demonstramos que a visão de neutralidade, no sentido de não se poder criar condições de desigualdade entre os agentes econômicos por meio da tributação, é utópica e irreal, uma vez que é inevitável a repercussão econômica dos tributos, em conformidade com o grau de elasticidade da demanda ou da oferta do mercado sobre o qual recair.

Além disso, os tributos não são utilizados pelo Estado apenas para a arrecadação de recursos, mas também para fins indutores, com efeitos extrafiscais, afastando a neutralidade fiscal, neste aspecto absoluto, pois a extrafiscalidade ou a indução necessariamente conduzem à interferência do tributo na economia.

Concluímos, portanto, que, ainda que se reconheça que a tributação inevitavelmente tem repercussão econômica, regra geral, deve-se buscar por imposições tributárias que não se caracterizem como fator determinante nas decisões sobre a alocação de recursos, ou seja, que não alterem os preços relativos, minimizando sua interferência nas decisões econômicas dos agentes de mercado.

Analisando o artigo 155, II, da Constituição Federal, verificamos que a competência para instituir o Imposto sobre Operações de Circulação de Mercadorias e Serviços - ICMS - foi atribuída aos Estados e ao Distrito Federal.

Além de dispor sobre a competência e as hipóteses de incidência do ICMS, o artigo 155 da Constituição Federal dispõe sobre as principais características do imposto, bem como sobre os princípios aplicáveis à sua incidência.

Determina, ainda, que a forma de incidência do ICMS, definição de contribuintes, disposições sobre regime de substituição tributária e o sistema de compensação de créditos para garantir a não cumulatividade, regulando a forma como os Estados e o Distrito 
Federal concederão ou revogarão isenções, incentivos e benefícios fiscais, devem ser definidos por lei complementar.

Quanto à não cumulatividade, a Constituição Federal estabelece expressamente a sua aplicação ao ICMS.

Concluímos que a não cumulatividade do ICMS prevista na Constituição Federal não é uma norma abstrata e genérica, mas uma norma específica, de aplicação imediata, não podendo, portanto, ser enquadrada como princípio, mas como regra que determina a técnica de tributação a ser adotada para instituição do imposto.

De qualquer forma, ainda que se trate de técnica/regra de tributação e não de princípio, por ter sido consagrada constitucionalmente, a não cumulatividade não pode ser desconsiderada pelo legislador infraconstitucional, devendo ser rigorosamente observada.

A não cumulatividade confere direito de crédito amplo ao contribuinte do ICMS, de aplicação objetiva, sofrendo apenas limitações impostas na própria Carta Magna.

É suficiente, portanto, que o ICMS tenha incidido sobre as operações anteriores para que nasça o direito de crédito na operação subsequente, permanecendo íntegro esse direito, mesmo que um dos contribuintes deixe de efetuar o pagamento do tributo.

Da análise do Texto Constitucional, conclui-se que apenas a isenção e não incidência têm o condão de restringir, reduzir ou amesquinhar o direito de crédito de ICMS, o princípio da não cumulatividade.

A legislação complementar não pode impor limitações à não cumulatividade até por uma questão de hierarquia das leis, estabelecendo restrições abusivas e que tornam o imposto cumulativo.

$\mathrm{O}$ artigo 155, XII, alínea $c$, da Constituição Federal autoriza à legislação complementar apenas a missão de disciplinar, instruir os procedimentos para apurar regime de compensação, já delineado na Carta Magna. 
Resumidamente, concluímos que a não cumulatividade é a técnica de tributação definida na Constituição Federal para o ICMS, de forma minuciosa e que não pode ser limitada pela legislação infraconstitucional.

Após delinear a não cumulatividade, abordamos a instituição dos regimes de substituição tributárias, que concentram a cobrança do ICMS em uma das fases da cadeia produtiva, sob o argumento de diminuir a evasão fiscal, por facilitar a fiscalização.

Concluímos que as substituições tributárias "para trás" e a concomitante, a princípio, não possuem nenhuma inconstitucionalidade ou ilegalidade, desde que observados os requisitos do artigo 128 do Código Tributário Nacional para sua instituição.

No entanto, a substituição tributária "para frente", na qual se antecipa a cobrança do tributo incidente sobre operação ainda não realizada, deve ser considerada inconstitucional, por ofensa ao princípio da tipicidade e da segurança jurídica.

O regime ofende, ainda, o princípio da não cumulatividade, uma vez que, ao antecipar o pagamento do tributo incidente nas operações subsequentes, o substituto não poderá se beneficiar do direito de crédito garantido pela não cumulatividade.

Se os valores reais forem inferiores aos valores arbitrados na pauta fiscal, deve ser assegurado o creditamento do valor excedente, sob pena de ofensa à não cumulatividade e configuração de confisco.

Resumidamente, concluímos que não se pode admitir que, a pretexto de combater a evasão fiscal, facilitar a fiscalização e aumentar a arrecadação, os Estados utilizem o regime de substituição tributária "para frente" ofendendo princípios e garantias constitucionais.

Traçadas as premissas básicas do perfil do ICMS, foram abordadas as distorções do referido imposto causadas pela guerra fiscal entre os Estados. 
Para entender o cenário, abordamos, primeiramente, questões referentes à adoção de forma federativa pelo Estado Brasileiro.

Restou demonstrado que a federação tem como elemento fundamental a coordenação de diversas ordens jurídicas sobre um mesmo Estado nacional, cada qual no âmbito de competências previamente definidas. A autonomia de cada ente do Estado Federal protege a ordem jurídica total, garantindo um sistema jurídico e político integrado.

Embora não exista um modelo único de federação, são elementos indispensáveis para diferenciar um Estado Federado de um Estado centralizado a soberania, a autonomia e a competência. Tais elementos devem ser delimitados de acordo com o modelo político de Federação a ser adotado pelo Estado, considerando-se seus anseios políticos, culturais, históricos e sociais.

No Brasil, a Constituição Federal de 1988, atualmente em vigor, adotou a forma federativa de Estado, composta pela União, Estados, Distrito Federal e Município, discriminando de forma rígida e detalhada a distribuição de rendas dos entes federativos, concedendo competências tributárias privativas para cada ente federativo.

A repartição de competências é uma das formas de garantir autonomia aos entes federativos, característica básica de uma Federação.

No entanto, assim como não há um modelo rígido de Federação, que é o moldado por cada Estado às suas necessidades e pretensões específicas, também não pode a autonomia ser delimitada de forma a designar um dogma para todos os sistemas, devendo ser moldada em maior ou menos grau conforme a independência que se pretende atribuir aos entes, concedendo-lhe as competências e poderes necessários para tanto.

Não obstante, a possibilidade de auto-organização e a atribuição de competência legislativa não são suficientes para que não haja hierarquia entre os entes federados, sendo obrigatório que todos os entes da Federação possuam autonomia financeira. Para que haja autonomia política ou administrativa é essencial a autonomia financeira. 
Por esse motivo, a Constituição Federal de 1988, além da repartição de competências legislativas mencionada anteriormente, optou por discriminar detalhadamente as competências tributárias da União Federal, dos Estados e Municípios.

A descriminação de competências tributárias não é, entretanto, requisito fundamental de um sistema federal. Exemplificadamente, tem-se o caso norte-americano, que, apesar de se tratar de uma Federação, não possui uma discriminação detalhada de competências tributárias, existindo, inclusive, a possibilidade de bitributação.

Isso porque a independência financeira dos Entes Federados pode ser assegurada por outras formas, como repartição e transferência de receitas entre as entidades, por exemplo.

Ademais, ficou demonstrado que a discriminação de competências, com a proibição de instituição de impostos semelhantes, tem como objetivo evitar que mais de um ente federado segue recursos de uma mesma manifestação da capacidade contributiva, protegendo o contribuinte de uma tributação excessiva. O objetivo é que o poder de tributar seja exercido sempre de modo a conservar a fonte tributável.

Nessa linha, a adoção da rigidez do sistema tributário não apenas evitou tal efeito, mas garantiu também a autonomia financeira dos entes federativos.

Posto isto, vimos que a competência para instituir o ICMS foi atribuída aos Estados e ao Distrito Federal. E, justamente para preservar a estrutura federativa, a Constituição Federal condicionou a concessão de incentivos fiscais à deliberação prévia e conjunta dos Estados e Distrito Federal, por meio de convênio.

A Constituição atribuiu à lei complementar a regulamentação da deliberação entre os Estados e o Distrito Federal para concessão de incentivos, o que foi feito pela Lei Complementar $\mathrm{n}^{\circ} 24 / 75$.

No entanto, os Estados desprezam as condições impostas pela Carta Magna, concedendo incentivos unilateralmente, sob o argumento de que pretendem promover o 
desenvolvimento econômico dos seus territórios, ao arrepio dos limites impostos na Lei Complementar $\mathrm{n}^{\circ} 24 / 75$, configurando o que se chama "guerra fiscal".

Para combater a concessão desses incentivos irregulares, os Estados que se sentem lesados têm a faculdade de ajuizar ação declaratória de inconstitucionalidade, com base no artigo 102, I, "a" e "f”, da Constituição Federal, com o objetivo de que a norma jurídica ilegítima seja devidamente retirada do ordenamento jurídico.

Apesar de esse procedimento já ter sido convalidado por decisões do Supremo Tribunal Federal, havendo, inclusive, proposta de súmula vinculante que reconhece que os incentivos concedidos sem prévia aprovação em convênio celebrado no âmbito do CONFAZ é inconstitucional, demonstrou-se que a eficácia das decisões da Corte Suprema é questionável.

Além da demora para realização dos julgamentos, os Estados já editam os benefícios por prazo determinado ou revogam a legislação antes do julgamento de sua constitucionalidade, resultando na perda de objeto da demanda. Não há a possibilidade, ademais, de obrigar o Estado a exercer a sua competência tributária para exigir o ICMS das operações pretéritas. Os Estados podem, ainda, editar leis concedendo anistia/remissão das dívidas.

Por fim, há a possibilidade de o Supremo Tribunal Federal modular os efeitos de sua decisão, por maioria de $2 / 3$ de seus membros, para que a decisão tenha efeitos ex nunc.

Ademais, não é aceitável que, tendo observado os preceitos legais, a legislação vigente e válida, os contribuintes sejam posteriormente penalizados pelo Estado que expediu tais normas, especialmente nos casos em que os contribuintes cumprem com determinados requisitos, tais como realização de investimentos.

Devido, portanto, à ineficácia das decisões proferidas em ações diretas de inconstitucionalidade, os Estados optam por aplicar sanções aos contribuintes adquirentes de mercadorias em operações interestaduais beneficiadas, previstas na Lei Complementar $n^{\circ} 24 / 75$. 
Destacamos que o artigo 155 da Constituição Federal, ao atribuir os benefícios cuja concessão deve ser regulamentada por lei complementar, se refere apenas a incentivos fiscais, não se referindo aos benefícios financeiros ou concessão de créditos presumidos.

Embora a Lei Complementar $n^{\circ}$ 24/75 tenha sido recepcionada pela Carta Magna de 1988, a novel Constituição nada dispõe sobre a necessidade de lei complementar regulamentar a concessão de incentivos financeiros; não se pode exigir que a concessão de referidos benefícios seja aprovada por convênio, conforme menciona a referida lei.

Concluímos, dessa forma, que é inconstitucional a aplicação da Lei Complementar $n^{\circ} 24 / 75$ a concessão de benefícios financeiros que se sujeitam apenas aos limites impostos pela lei Complementar $n^{\circ}$ 101/2000 (Lei de Responsabilidade Fiscal).

Ademais, a imposição cumulativa da glosa de créditos aos destinatários das operações beneficiadas por incentivos irregulares e a exigência do ICMS que deixou de ser recolhido pelo remetente no Estado de origem não têm amparo constitucional.

Primeiro porque, conforme exposto acima, as únicas limitações ao direito de crédito estão previstas na Constituição - isenção e não incidência -, de forma que a vedação ao crédito imposta pela Lei Complementar $n^{\circ} 24$, de 1975, só e aplicável se o incentivo fiscal se enquadrar nessas modalidades.

Ao determinar que o Estado de origem deve exigir o imposto que não foi recolhido em virtude da concessão irregular do beneficio e, cumulativamente, determinar o estorno do crédito pelo destinatário da operação, a lei complementar ofende a estrutura federativa, a distribuição de competências tributárias pela Constituição Federal, o principio da não cumulatividade e, ainda, configura enriquecimento ilícito do Estado de destino.

Ora, a consequência lógica da exigência do imposto pelo Estado de origem é o direito ao crédito no Estado de destino.

Ademais, o Estado de destino não pode exigir tributo cuja competência é atribuída a outro Estado, pela Constituição Federal. Em virtude da autonomia política e financeira dos 
Estados, também não há como obrigar o Estado de origem a exigir o tributo. A única consequência vislumbrada nesses casos seria eventual responsabilização nos termos da Lei Complementar 101 de 2000 (Lei de Responsabilidade Fiscal).

Destacamos, ainda, que a maioria dos Estados que aplicam as sanções previstas na Lei Complementar de 1975 também concede incentivos ao arrepio da referida lei complementar, ofendendo o princípio da moralidade, previsto no artigo 37 da Constituição Federal.

Também não se pode admitir a vedação de crédito por meio de atos dos Poderes Executivo ou Legislativo, o que configura ofensa ao princípio da separação de poderes, por interferência na competência exclusiva do Poder Judiciário.

Por fim, esclarecemos que não se pode transferir aos contribuintes a responsabilidade por verificar se as operações que realiza com contribuintes localizados em outros Estados são beneficiadas, se os incentivos são regulares e se há medidas judiciais questionando a sua validade.

Concluímos que, no cenário atual, a ferramenta para coibir a concessão irregular de benefícios, que é o ajuizamento de ação declaratória de inconstitucionalidade, é na prática ineficaz. Assim, os Estados optam por perseguir os contribuintes destinatários das operações irregulares, aplicando-lhes sanções que, no entanto, estão eivadas de diversas inconstitucionalidades.

Colocadas essas premissas, passou-se à análise da possibilidade de reforma tributária que tenha por objeto a supressão de competências tributárias atualmente existentes, com a criação de novas figuras tributárias e nova distribuição de competências.

Destacamos que esse cenário só pode ser alterado após uma reforma tributária que modifique a estrutura da tributação pelo ICMS, com o objetivo de eliminar as distorções decorrentes de concessões de incentivos irregulares pelos Estados. 
Verificamos que a Constituição Federal Brasileira caracteriza-se como rígida, sujeitando-se qualquer alteração às limitações impostas em seu próprio texto, no artigo 60.

Dessa forma, para que se tenha uma reforma, é necessário o cumprimento de requisitos formais e materiais.

Entre os limites materiais, denominados de cláusulas pétreas, encontra-se a estrutura federativa de Estado e os direitos e garantias individuais.

Nesse contexto, qualquer reforma, inclusive tributária, deve preservar a Federação e os direitos e garantias individuais.

Assim, é expressamente proibida a reforma constitucional que objetive impor um Estado unitário com poder político concentrado. Deve-se manter o Estado como uma Federação em que coexistem entes autônomos.

Isso não significa que não possa haver uma reformulação no âmbito da estrutura federativa. Conforme demonstrado, não há um modelo único de Federação, cabendo a cada Estado instituir essa forma de governo nos moldes em que julgar adequada às suas necessidades particulares.

Nesse contexto, a necessidade de manter a autonomia dos entes não impede que se altere, por emenda constitucional, a repartição de competências tributárias. Pois, como já restou consignado acima, a autonomia financeira não é garantida apenas por esta forma de distribuição de receitas tributárias.

Há outros instrumentos que viabilizam a autonomia dos entes federativos, tais como a transferência de receitas tributárias e a criação de fundos e participação, que, inclusive, já são utilizados pelo nosso sistema.

No caso da PEC 233, encaminhada pelo Pode Executivo à Câmara dos Deputados em 2008, mencionada acima, assim como se verá em qualquer proposta nesse sentido, as 
alterações provocam aumentos e/ou reduções na arrecadação de tributos, muitos, inclusive, sujeitos à extinção.

Tais alterações não podem, entretanto, ser consideradas inconstitucionais, a priori, por ofensa ao artigo $60, \S 4^{\circ}$, da Constituição federal, ainda que haja redução de receita de um ente federativo. Tal análise está sujeita a verificação de eventual supressão de autonomia financeira de qualquer um dos entes da Federação.

Não havendo essa ofensa, não há nenhum impedimento para que se introduza, por emenda constitucional, reforma nesse sentido. Note-se, inclusive, que, ainda que haja supressão de competência tributária, é possível manter a autonomia com a adoção de repartição de receitas e criação de fundos.

Ainda com relação às cláusulas pétreas, deve ser destacado que não podem ser atingidos por emenda constitucional os direitos e garantias individuais.

Com efeito, a repartição rígida de competências foi introduzida com o objetivo de proteger o direito de os contribuintes não sofrerem tributação excessiva. Por conseguinte, a reforma, além de não excluir o pacto federativo, não pode ofender os direitos dos contribuintes.

Portanto, a Constituição Federal está sujeita a mudanças, no âmbito da discriminação de competências tributários tributárias, desde que não sejam violados os direitos e garantias individuais dos contribuintes e as estruturas republicana e federativa.

Vê-se, portanto, que, na verdade, o único empecilho para a reforma é uma questão política, de disputa de poderes entre os Entes da Federação. 


\section{REFERÊNCIAS}

AFONSO, José Roberto Rodrigues; ARAÚJO, Érika Amorim. Pós-Constituinte e Impostos Indiretos: Deformar ou Reformar? In: PINTO, Márcio Percival Alves; BISOTO JR., Geraldo (Orgs.). Política Fiscal e Desenvolvimento no Brasil. Campinas, SP: Unicamp, 2006. p. 289-330.

AMARO, Luciano. Direito Tributário Brasileiro. 10. ed. atualizada. São Paulo: Saraiva, 2004.

ÁVILA, Humberto. A distinção entre princípios e regras e a redefinição do dever de proporcionalidade. Revista Diálogo Jurídico, Salvador, CAJ - Centro de Atualização Jurídica, v. I, n. 4, jul. 2001. Disponível em:

$<$ http://www.direitopublico.com.br/pdf_4/dialogo-juridico-04-julho-2001-humbertoavila.pdf >. Acesso em: 14 ago. 2012.

ATALIBA, Geraldo. Sistema Constitucional Tributário Brasileiro. São Paulo: Revista dos Tribunais, 1968.

BALEEIRO, Aliomar. Direito tributário brasileiro. Atualizada por Misabel Abreu Derzi. Rio de Janeiro: Forense, 2005.

. Uma Introdução à Ciência das Finanças. 16. ed. rev. e atualizada por Dejalma de

Campos. Rio de Janeiro: Forense, 2006.

BARRETO, Paulo Ayres. Contribuições: regime jurídico, destinação e controle. São Paulo: Noeses, 2006.

BASTO, José Guilherme Xavier de. A tributação do consumo e a sua coordenação internacional. Lisboa: Centro de Estudos Fiscais, 1991. (Coleção Cadernos de Ciência e Técnica Fiscal, 164).

BATISTA, Luiz Rogério Sawaya. Créditos do ICMS na Guerra Fiscal. São Paulo: Quartier Latin, 2012.

BECATTINI, Stefania; CARDOSO, Bruno Oliveira. A Glosa de Créditos de Incentivos Fiscais de ICMS. Revista de Direito Tributário, São Paulo: Associação Paulista de Estudos Tributários, n. 5, p. 149-156, mar. 2005.

BONILHA, Paulo Celso Bergstrom. Alguns aspectos do imposto de circulação de mercadorias. In: NOGUEIRA, Ruy Barbosa (Coord.). Direito Tributário - Estudos de problemas e casos tributários. São Paulo: José Bushatsky, 1973. p. 285-317. 
IPI e ICMS: Fundamentos da Técnica não cumulativa. São Paulo: Resenha Tributária; IBDT - Instituto Brasileiro de Direito Tributário, 1979.

. Notas sobre as deformações da incidência plurifásica do ICMS. Direito Tributário Atual, São Paulo: Dialética, n. 23, p. 402-409, 2009.

BRASIL. Subchefia de Assuntos Parlamentares. EM n 00016/MF. Brasília: 26 fev. 2008. Disponível em:

<http://www.planalto.gov.br/ccivil_03/projetos/EXPMOTIV/MF/2008/16.htm>. Acesso em: 23 set. 2012.

Supremo Tribunal Federal. Ação Direta de Inconstitucionalidade $n^{\circ}$ 2.056/MS. Relator: Ministro Gilmar Mendes. Julgamento: 30 maio 2007. Órgão Julgador: Tribunal Pleno. Publicação: DJ 113, 14 jun. 2007.

Supremo Tribunal Federal. Medida Cautelar em Ação Cautelar n ${ }^{\circ}$ 2611/MG. Relatora: Min. Ellen Gracie. Julgamento: 07 maio 2010. Divulgação: 12 maio 2010. Publicação: DJe-085 13 maio 2010.

. Supremo Tribunal Federal. Repercussão Geral no Recurso Extraordinário n. 628.075/RS. Relator: Ministro Joaquim Barbosa. Julgamento: 13 out. 2011. Órgão Julgador: Plenário. Publicação: 01 dez. 2011.

. Tribunal de Justiça do Estado de São Paulo. Apelação Mandado de Segurança $n$. 518.847.5/5-00. Relator: Desembargador Nogueira Diefenhaler. Julgamento: 23 jul. 2007. Órgão Julgador: $7^{\text {a }}$ Câmara de Direito Público. Publicação: 09 out. 2007.

BRAZUNA, José Luis Ribeiro. Defesa da Concorrência e Tributação - À Luz do artigo 146-A da Constituição. São Paulo: Quartier Latin, 2009. (Série Doutrina Tributária, V. II).

BRITO, Edvaldo Pereira de. ICMS: inconstitucionalidade da pauta fiscal. In: ROCHA, Valdir de Oliveira (Org.). Grandes Questões atuais de direito tributário. São Paulo: Dialética, 2005. p. 88-109.

CALIENDO, Paulo. Direito Tributário e Análise Econômica do Direito: Uma visão crítica, Rio de Janeiro: Elsevier, 2009.

CAMARGO, Guilherme Bueno. A Guerra Fiscal e seus efeitos: autonomia x centralização. In: CONTI, José Mauricio (Org.). Federalismo Fiscal. Barueri, SP: Manole, 2004. p. 193199.

CARDOSO, Lais Vieira. A Seletividade no IPI. In: PEIXOTO, Marcelo Magalhães (Coord.). IPI - Aspectos Jurídicos Relevantes. São Paulo: Quartier Latin, 2003. p. 246262. 
CARRAZZA, Roque Antonio. Curso de Direito Constitucional Tributário. 19. ed., rev. e ampl. até a EC 39/2002. São Paulo: Malheiros, 2003.

ICMS. 15. ed., rev. e ampl. até a EC 67/2011, de acordo com a Lei Complementar 87/1996 com suas ulteriores modificações. São Paulo: Malheiros, 2011.

CARVALHO, Paulo de Barros. Introdução ao Estudo do Impôsto sobre Produtos Industrializados. Revista de Direito Público, São Paulo, v. 11, p. 75-85, 1969.

CINTRA, Carlos César Sousa. A Não-Cumulatividade no Direito Tributário Brasileiro: Teoria e Prática. In: MACHADO, Hugo de Brito. Não-Cumulatividade Tributária. São Paulo: Dialética, 2009. p. 103-151.

COÊLHO, Sacha Calmon Navarro. Curso de direito tributário brasileiro. 2. ed. Rio de Janeiro: Forense, 1999.

CONTI, José Mauricio. Federalismo Fiscal e Reforma Tributária: Utopia ou Realidade? In: SCHOUERI, Luis Eduardo (Org.). Direito Tributário. Homenagem a Paulo de Barros Carvalho. v. 1. São Paulo: Quartier Latin, 2008. p. 907-915.

. Princípios Tributários da Capacidade Contributiva e da Progressividade. São Paulo: Dialética, 1996.

COSTA, Alcides Jorge. ICM na Constituição e na Lei Complementar. São Paulo: Resenha Tributária, 1979.

COSTA, Regina Helena. Princípio da Capacidade Contributiva. São Paulo: Malheiros, 1993.

DERZI, Misabel Abreu Machado. Distorções do Princípio da não-cumulatividade no ICMS - Comparação com o IVA Europeu. In: COELHO, Sacha Calmon Navarro et al. Temas de Direito Tributário: I Congresso Nacional da Associação Brasileira de Direito Tributário. Belo Horizonte: Livraria Del Rey, 1998. p. 9-151.

; SANTIAGO, Igor Mauler. A Harmonização dos IVAS do Brasil para o desenvolvimento produtivo In: SARAIVA FILHO, Oswaldo Othon de Ponte; VASQUES, Sérgio; GUIMARÃES, Vasco Branco (Orgs.). IVa para o Brasil - Contributos para a Reforma da Tributação do Consumo. Belo Horizonte: Fórum, 2007. p. 522-586.

DI PIETRO, Juliano. Repartição das Receitas Tributárias: A repartição do produto da arrecadação. As transferências intergovernamentais. In: CONTI, José Mauricio (Org.). Federalismo Fiscal. Barueri, SP: Manole, 2004. p. 67-100.

ELALI, André. O Federalismo Fiscal Brasileiro e o Sistema Tributário Nacional. São Paulo: MP Editora, 2005. 
EMERENCIANO, Adelmo da Silva. Modificação na Competência Tributária por Emenda Constitucional. A Contribuição para Custeio do Serviço de Iluminação Pública - Emenda Constitucional 39/2002. In: SANTI, Eurico Marcos Diniz de (Coord.). Curso de Especialização em Direito Tributário: Estudos Analíticos em Homenagem a Paulo de Barros Carvalho - Rio de Janeiro: Forense, 2007. p. 897-920. (Livro IV - Controle da Incidência Tributária).

FERREIRO LAPTAZA, José Juan. Direito Tributário: teoria geral do tributo. Barueri, SP: Manole, 2007.

GAMA, Evandro Costa. A Reforma Tributária e a Autonomia Financeira das Entidades Subnacionais. In: CONTI, José Mauricio (Org.). Federalismo Fiscal. Barueri, SP: Manole, 2004. p. 137-162.

GUIMARÃES, Ylves José de Miranda Guimarães. ICM: Análise e Princípios Estruturais. São Paulo: Ltr, 1975.

JARACH, Dino. O fato imponível: Teoria Geral do Direito Tributário Substantivo. Trad. Dejalma de Campos. São Paulo: Revista dos Tribunais, 1989.

LUNARDELLI, Pedro Guilherme Accorsi. A Não-Cumulatividade do ICMS - uma aplicação da teoria sobre as regras do Direito e as regras dos jogos. São Paulo: Quartier Latin, 2009.

MARIANO, Antonio Paulo; WERNECK, Raphael; BEZERRA, Sandra Regina Alencar. Substituição Tributária no ICMS: aspectos jurídicos e práticos. São Paulo: IOB, 2009.

MATTOS, Aroldo Gomes de. A cumulatividade do ICMS. Revista Tributária e de Finanças Públicas, São Paulo: Revista dos Tribunais, ano 15, n. 72, p. 19-30, jan.-fev. 2007.

. ICMS - Substituição tributária 'para frente' e a Lei Complementar 87/1996, art. 10. In: ROCHA, Valdir de Oliveira. O ICMS e a Lei Complementar 87/1996. São Paulo: Dialética, 1996.

MELO, Fábio Soares de. Incentivos Fiscais e Segurança Jurídica. In: MARTINS, Ives Gandra da Silva; ELALI, André; PEIXOTO, Marcelo Magalhães. Incentivos Fiscais Questões Pontuais nas Esferas Federal, Estadual e Municipal. São Paulo: MP Editora, 2007. p. 137-162.

MELO, José Eduardo Soares de. ICMS - Teoria e Prática. 9. ed. São Paulo: Dialética, 2006.

. O ICMS, os Benefícios Fiscais Concedidos unilateralmente por Certos Estados, as Medidas de Defesa Judicial e Extrajudicial Adotadas por outros Estados e Consequências 
para os Contribuintes. In: ROCHA, Valdir de Oliveira (Coord.). Grandes Questões Atuais do Direito Tributário, São Paulo: Dialetica, v. 9, p. 325-348, 2005.

Questões. Revista de Direito Tributário, São Paulo, v. 64, p. 269-308, 1994.

MENDONÇA, Christine. A Não-Cumulatividade do ICMS. São Paulo: Quartier Latin, 2005 .

MIRAGILIA, Rafael Triginelli Nery. Neutralidade e Justiça Constitucional na Tributação do Consumo: princípio da não-cumulatividade em perspectiva. In: SILVA, Paulo Roberto Coimbra; BERNARDES, Flávio Couto; FONSECA, Maria Juliana. (Coords.). Tributação sobre o consumo. São Paulo: Quartier Latin, 2008. p. 341-358.

MOREIRA, Gilberto Ayres. A “Guerra Fiscal” e os limites ao princípio da nãocumulatividade do ICMS. Revista de Direito Tributário, Rio de Janeiro: Malheiros, n. 85, p. 235-250, 2002.

OLIVEIRA, Julio Maria de; MIGUEL, Carolina Romanini. Guerra Fiscal ou Terrorismo Estatal. In: SANTI, Eurico Marcos Diniz de; ZILVETI, Fernando Aurelio (Coords.). Tributação Empresarial. São Paulo: Saraiva, 2009. p. 99-150.

OLIVEIRA, Regis Fernandes de. Curso de Direito Tributário. São Paulo: Revista dos Tribunais, 2006.

PEIXOTO, Daniel Monteiro. Guerra Fiscal via ICMS: Controle dos Incentivos Fiscais e os Casos "FUNDAP” e "COMUNICADO CAT N. 36/2004". In: MARTINS, Ives Gandra da Silva; ELALI, André; PEIXOTO, Marcelo Magalhães. Incentivos Fiscais - Questões Pontuais nas Esferas Federal, Estadual e Municipal. São Paulo: MP Editora, 2007. p. 6790.

PORFIRIO JUNIOR, Nelson de Freitas. Federalismo, Tipos de Estado e Conceito de Estado Federal. In: CONTI, José Mauricio Conti (Org.). Federalismo Fiscal. Barueri, SP: Manole, 2004. p. 1-13.

REIS, Elcio Fonseca. Federalismo Fiscal: competência concorrente e normas gerais de direito tributário. Belo Horizonte: Mandamentos, 2000.

ROCHA, Carmen Lúcia Antunes. República e Federação no Brasil - Traços constitucionais da organização política brasileira. Belo Horizonte: Del Rey, 1997.

ROLIM, João Dácio. Não-Cumulatividade (Valor Agregado?). In: MACHADO, Hugo de Brito (Coord.). Não-Cumulatividade Tributária. São Paulo: Dialética, 2009. p. 253-261.

RONZANI, Guilherme Della Garza. Princípios da Tributação na Origem e da Tributação no Destino no Contexto da 'Guerra Fiscal'. In: SILVA, Paulo Roberto Coimbra; 
BERNARDES, Flavio Couto; FONSECA, Maria Juliana (Coords.). Tributação sobre o Consumo. São Paulo: Quartier Latin, 2008. p. 183-203.

SAMPAIO, Maria de Conceição. Tributação do consumo no Brasil: aspectos teóricos e aplicados. BIDERMAN, Ciro; ARVATE, Paulo (Orgs.). Economia do setor público no Brasil. Rio de Janeiro: Elsevier, 2004.

SCHOUERI, Luis Eduardo. Direito Tributário. São Paulo: Saraiva, 2011.

. Discriminação de Competências e Competência Residual. In: ; ZILVETI, Fernando Aurelio. Direito Tributário: estudos em homenagem a Brandão Machado. São Paulo: Dialética, 1998. p. 82-115.

2005.

Normas Tributárias Indutoras e Intervenção Econômica. Rio de Janeiro: Forense,

. Livre concorrência e tributação. In: ROCHA, Valdir de Oliveira (Coord.).

Grandes questões atuais do Direito Tributário. v. 11, São Paulo: Dialética, 2007. p. 214271.

SILVA, Fernando Antonio Rezende da. A Moderna Tributação do Consumo. Texto para discussão, n. 33, jun. 1993. Disponível em:

<http://www.ipea.gov.br/portal/images/stories/PDFs/TDs/td_0303.pdf>. Acesso em: 17 dez. 2012.

A reforma tributária e a federação. Rio de Janeiro: FGV, 2009.

SILVEIRA, Paulo Antônio Caliendo Velloso da. Direito tributário e análise econômica do Direito: uma visão crítica. Rio de Janeiro: Elsevier, 2009.

SIQUETTO, Paulo Roberto. Os projetos de reforma constitucional tributária e o federalismo Fiscal. In: CONTI, José Mauricio (Org.). Federalismo Fiscal. Barueri, SP: Manole, 2004. p. 263-291.

SOUZA, Rubens Gomes de. Os impostos sobre o valor acrescido no sistema tributário. Revista de Direito Administrativo. Rio de Janeiro: FGV, n. 110, p. 17-26, out./dez. 1972.

TEIXEIRA, Alessandra Machado Brandão. A Tributação sobre o Consumo de Bens e Serviços. Belo Horizonte: Mandamentos, 2002.

TILBERY, Henry. O conceito de essencialidade como critério de tributação. Direito Tributário Atual. São Paulo: IBDT; Resenha Tributária, v. 10, p. 2969-3031, 1990. 
TIPKE, Klaus; YAMASHITA, Douglas. Justiça Fiscal e princípio da capacidade contributiva. São Paulo: Malheiros, 2002.

TIPKE, Klaus; LANG, Joachim. Direito Tributário. Porto Alegre: Sergio Antonio Fabris, 2008.

TORRES, Ricardo Lobo. É possível a criação do IVA no Brasil? In: SARAIVA FILHO, Oswaldo Othon de Ponte; VASQUES, Sérgio; GUIMARÃES, Vasco Branco (Orgs.). IVA para o Brasil - Contributos para a Reforma da Tributação do Consumo. Belo Horizonte: Fórum, 2007. p. 19-36.

O princípio da não-cumulatividade e o IVA no Direito Comparado. In:

MARTINS, Ives Gandra da Silva (Coord.). O Princípio da não-cumulatividade. São Paulo: Revista dos Tribunais; Centro de Extensão Universitária, 2004. p. 139-170. (Pesquisas tributárias: Nova Série 10).

Tratado de Direito Constitucional Financeiro e Tributário - Valores e Princípios Constitucionais Tributários. Rio de Janeiro: Renovar, 2005.

VANONI, Ezio. Natureza e Interpretação das Leis Tributárias. Trad. Rubens Gomes de Sousa. Rio de Janeiro: Edições Financeiras S/A, 1932.

ZILVETI, Fernando Aurelio. Princípios de Direito Tributário e a Capacidade Contributiva. São Paulo: Quartier Latin, 2004.

. Variações sobre o princípio da neutralidade no direito tributário internacional. Direito Tributário Atual, São Paulo: Dialética, v. 19, p. 24-40, 2005.

ZIMMERMANN, Augusto. Teoria Geral do Federalismo Democrático. 2. ed. Rio de Janeiro: Lúmen Júris, 2005. 